Cátia Sueli Fernandes Primon

Análise do conhecimento de conteúdos fundamentais de Genética e Biologia Celular apresentado por graduandos em Ciências Biológicas. 
Cátia Sueli Fernandes Primon

\section{Análise do conhecimento de conteúdos fundamentais de Genética e Biologia Celular apresentado por graduandos em Ciências Biológicas.}

Dissertação apresentada ao Instituto de Biociências da Universidade de São Paulo, para a obtenção de título de Mestre em Ciências Biológicas, na área de Biologia/Genética.

Orientador: Prof. Dr. José Mariano Amabis

São Paulo

2005 
Primon, Cátia Suelí Fernandes

Análise do conhecimento de conteúdos fundamentais de Genética e Biologia Celular apresentado por graduandos em Ciências Biológicas.

135 páginas

Dissertação (Mestrado) - Instituto de Biociências da Universidade de São Paulo. Departamento de Genética e Biologia Evolutiva

1. Genética 2. Aprendizagem significativa

I. Universidade de São Paulo. Instituto de Biociências. Departamento de Genética e Biologia Evolutiva.

\section{Comissão Julgadora:}


Aos meus pais, Álvaro e Sueli, por terem me proporcionado as oportunidades que não tiveram; pelo apoio e amor incondicional. 
$\mathcal{N a ̃ o ~ e x i s t e ~ a l g u e ́ m ~}$

que nunca teve um professor na vida,

Assim como não há alguém

que nunca tenha tido um aluno.

Se existem analfabetos,

provavelmente não é por vontade dos professores.

Se existem letrados,

é porque um dia tiveram seus professores.

Se existem Prêmios $\mathcal{N}$ obel,

é porque alunos superaram seus professores.

Se existem grandes sábios,

é porque transcenderam suas funções de professores.

Quanto mais se aprende, mais se quer ensinar.

Quanto mais se ensina, mais se quer aprender.

Içami Tiba 


\section{Agradecimentos}

Agradeço ao meu orientador, prof. Dr. José Mariano Amabis pelo aprendizado, que iniciou no Ensino Médio através de seus livros e posteriormente quando tive o prazer de tê-lo como orientador. Pelos momentos de orientação e troca de idéias, minha gratidão e admiração por tão competente mestre.

À Prof ${ }^{a} \operatorname{Dr}^{\mathrm{a}}$ Maria Elena Infante-Malachias, amiga que surgiu nos momentos de maior dificuldade e tornou-se peça fundamental para a conclusão deste trabalho. A ela serei eternamente grata.

Ao Prof. Dr. Armando Luis Serra, amigo que sempre me incentivou e me mostrou o caminho quando não sabia por onde começar.

À Dr $^{\mathrm{a}}$ Silvana Santos pela leitura do texto inicial e pelas sugestões pertinentes.

À Prof ${ }^{\mathrm{a}} \mathrm{Dr}^{\mathrm{a}}$ Vera Novaes pelo auxílio na redação da metodologia no período de férias em Ubatuba.

Aos amigos do Grupo de Pesquisa em Ensino de Genética, Rodrigo, Solange e Maria Elena, por terem me aceito de coração aberto no grupo e pelo prazer da convivência que gerou muito aprendizado.

Aos funcionários da secretaria de Pós-Graduação, em especial ao Helder, pelas orientações e dedicação ao pós-graduando.

À Helenice e Dayse, da secretaria do Departamento de Genética e Biologia Evolutiva, pela atenção e dedicação com que nos atendem e pelo apoio e conforto nos momentos de dificuldades.

Às bibliotecárias do Instituto de Biociências pela simpatia e atenção no atendimento. Em especial à Inês pelo auxílio na revisão bibliográfica e no Abstract.

Aos meus pais, Álvaro e Sueli por terem investido além de suas posses em minha formação inicial; por terem me ensinado que as dificuldades existem para que possamos transpô-las e para nos fortalecer.

Ao Paulo, meu marido, companheiro eterno que sempre acreditou em mim e me amparou nos momentos de dificuldade; por sua compreensão, carinho e presença ao longo do período de elaboração deste trabalho. 
Aos meus filhos, Rafael, Rodrigo e Juliana, os motivos de minha existência; que os resultados desse trabalho possam lhes trazer benefícios.

Aos meus alunos, de ontem, de hoje e de amanhã, por terem me ensinado que ensinar é aprender a cada dia.

Aos coordenadores e professores das Instituições de Ensino que permitiram a aplicação desta pesquisa.

Aos alunos que participaram das entrevistas, sem os quais este trabalho seria impossível.

A Deus, por me dar força e coragem para seguir em frente e superar as dificuldades.

A todos os que contribuíram de maneira direta ou indireta para a realização deste trabalho, meu muito abrigada. 


\section{$\underline{\text { Índice }}$}

Capítulo I.- Introdução. $\quad 01$

I.1 - Por que estudar Genética 01

I.2 - Dificuldades no Ensino e na aprendizagem de Genética 03

$\begin{array}{ll}\text { I.3 - Teoria da Aprendizagem Significativa } & 07\end{array}$

I.4 - Teoria das Inteligências Múltiplas 09

$\begin{array}{ll}\text { Capítulo II.- Objetivos } & 11\end{array}$

II.1.- Objetivo Geral 11

II.2 - Objetivos específicos 11

$\begin{array}{ll}\text { Capítulo III - Métodos } & 12\end{array}$

III.1 - Seleção das questões do ENC-BIO/2002 12

III.2 - Análise do relatório expedido pelo MEC 13

III.3 - Pesquisa em livros didáticos 14

III.4 - Aplicação de questionários $\quad 14$

III.5 - Realização de entrevistas 15

$\begin{array}{ll}\text { Capítulo IV - Resultados } & 17\end{array}$

IV.I - Análise das questões do ENC-Biologia/2002 17

IV.I.1 - Questões 18

IV.II - Análise das entrevistas - Parte A 44

IV.II - Análise das entrevistas - Parte B 93

$\begin{array}{ll}\text { Capítulo V. - Discussão } & 105\end{array}$

$\begin{array}{ll}\text { Capítulo VI - Conclusões } & 119\end{array}$

$\begin{array}{lr}\text { Capítulo VII - Resumo } & 120\end{array}$

Capítulo VIII - Abstract 121

$\begin{array}{ll}\text { Capítulo IX - Bibliografia } & 122\end{array}$

$\begin{array}{ll}\text { Capítulo X - Anexos } & 130\end{array}$

$\begin{array}{ll}\text { X.I - Questões do ENC-Biologia/2002 } & 130\end{array}$

X.II - Parte I - Autorização 134

X.II - Parte II - Disponibilidade para entrevista 135 



\section{Introdução}

\section{I.1 Por que estudar Genética?}

Griffiths e colaboradores (2001) mencionam duas razões básicas como justificativa para a importância do estudo da Genética. Primeiro, a Genética chegou para ocupar uma posição fundamental na Biologia como um todo; portanto, é essencial o entendimento da Genética para qualquer estudo sério sobre a vida. Segundo, a Genética, como nenhuma outra disciplina científica, tem se tornado fundamental para a compreensão de inúmeros aspectos dos interesses humanos. De fato, as questões genéticas parecem emergir diariamente, nos programas de televisão, nas prateleiras dos supermercados, nos noticiários, nas propagandas, enfim em diversos aspectos de nossas vidas. Isso demanda que o cidadão tenha um certo grau de conhecimento científico na área para compreender as potencialidades e as limitações da ciência e da tecnologia e ter uma participação responsável na sociedade moderna (Wood-Robinson e col., 1998). A necessidade desse conhecimento para o exercício da cidadania é preconizada no volume 3 dos Parâmetros Curriculares Nacionais para o Ensino Médio ( PCN, Ciências da Natureza, Matemática e suas Tecnologias, 1999), quando diz: “o conhecimento biológico deve ser bem compreendido, a ponto do estudante utilizar os conceitos em novas situações de aprendizado, no seu cotidiano."

Segundo Torres (2001), atravessamos um período no qual a Biologia é a mais comentada das ciências e a que ocupa maior espaço na mídia. Para o autor alguns indicadores mostram o porquê dessa popularização: a preocupação com a saúde e o bem estar físico dos indivíduos, a liberdade sexual e as doenças sexualmente transmissíveis, os cuidados com o meio ambiente e a interferência no patrimônio genético. Para ele, a intensa divulgação e popularidade da Biologia trazem novas responsabilidades, especialmente para os professores de Ensino Médio, os quais são, muitas vezes, a única fonte de consulta e esclarecimento dos estudantes. Neste âmbito, o papel do professor é de fundamental importância, pois devemos levar em conta que os estudantes recebem informações das mais diversas fontes, como 
propagandas na televisão, nas ruas, em revistas, através da Internet, noticiários em geral, etc. Tais informações nem sempre são cientificamente corretas e, portanto, é nas escolas, por meio dos professores, que os jovens devem adquirir informações pautadas em fundamentos científicos que podem subsidiar discussões. Desta forma, os estudantes podem desenvolver uma consciência crítica frente às informações da mídia.

No entanto, para que o professor do Ensino Médio possa exercer tal função na sociedade torna-se fundamental que seja um profissional bem formado e informado. Sendo assim, o cidadão em geral, seja ele professor ou estudante, deve ser capaz de emitir opinião, de colocar-se criticamente diante dos fatos.

Um dos objetivos dos currículos de ciências de muitos países consiste em proporcionar a formação científica para todos os estudantes como parte de sua formação geral, de modo a permitir que os estudantes do Ensino Médio sejam capazes de tomar decisões pessoais relacionadas aos resultados das novas tecnologias (Wood-Robinson e col. 1998). Nesse contexto do ensino de Genética deve ser enfocado do ponto de vista da alfabetização científica. Os autores apontam três funções básicas para a educação científica: função utilitária, função cultural e função democrática

a) A função utilitária objetiva que os indivíduos sejam capazes de aplicar, na prática, os conhecimentos científicos que lhes forem úteis. Por exemplo, em uma família na qual há casos de doenças genéticas, um casal que pretende ter filhos deverá ser capaz de avaliar a situação e decidir se estão dispostos a procurar um serviço de aconselhamento genético. Ou ainda quando for ao supermercado deve ter conhecimento suficiente para avaliar se deseja ou não consumir um alimento em cuja composição há um componente transgênico.

b) A função cultural pressupõe que os indivíduos entendam a ciência como patrimônio cultural da humanidade. Segundo Silveira (2003), além de conhecer eventos históricos como, por exemplo, o trabalho de Mendel, a pessoa deve ser capaz de compreender as discussões da época atual, na qual a Genética tem sido o foco principal da mídia em geral. 
c) A função democrática implica que, por meio da utilização dos conhecimentos científicos, os indivíduos apliquem seus conhecimentos para entender e participar dos debates relacionados a temas científicos. Os cidadãos têm o direito de participar de discussões sobre a legalização das pesquisas de clonagem reprodutiva, terapêutica, plantação e comercialização de alimentos transgênicos, células tronco, etc. Só é capaz de debater com argumentos válidos, aquele que é cientificamente bem formado e informado, somente assim o educando se tornará um cidadão consciente, com poder de decisão. Os estudantes terão que acompanhar, opinar e entender esses processos que já fazem parte de suas vidas, pois em seu cotidiano estão imersos numa sociedade de tecnologias genéticas, mesmo que não tenham consciência disso.

Em relação à alfabetização biológica, Krasilchik (2001) afirma que alguns pesquisadores consideram quatro estágios de alfabetização. O primeiro é o da alfabetização nominal, em que são identificados termos, mas a sua conceituação é ingênua ou desconhecida; o segundo estágio é o da alfabetização funcional, em que os termos são conhecidos e definidos por memorização sem compreensão real do seu significado; o terceiro é o estágio estrutural, em que são compreendidos os conceitos e princípios unificadores da Biologia; o quarto e último estágio de alfabetização biológica é o multidimensional, em que aspectos biológicos são analisados sob o ponto de vista do seu desenvolvimento histórico e influenciados por aspectos científicos, tecnológicos e sociais. Para a autora, torna-se primordial nos dias atuais, uma alfabetização biológica, haja vista a presença da Biologia no cotidiano de cada um de nós.

\section{I.2 Dificuldades no Ensino e na Aprendizagem de Genética}

David Ausubel e colaboradores (1980) defendem a idéia de que toda aprendizagem deve ser significativa, isto é, que o estudante relacione a nova informação a ser aprendida com o que já sabe, dando-lhe um lugar dentro de um todo mais amplo. Só assim, o estudante seria capaz de aplicar o que foi aprendido em determinada situação a uma variedade de situações semelhantes. Segundo esses 
autores, quanto mais significativo for o conteúdo aprendido, mais rápido será o processo de aprendizagem e quanto mais significativa for à aprendizagem, mais duradoura será a retenção na memória. Só será de fato aprendido aquilo que fizer sentido para o estudante, caso contrário ele irá reproduzir as informações nas avaliações e em seguida descartar tal conteúdo.

Segundo Cho (1985), os estudantes trazem para a escola pré-concepções baseadas em experiências vivenciadas anteriormente. Quando estas pré-concepções diferem das que são aceitas pela disciplina, os estudantes consideram errada a abordagem escolar, fazendo com que as pré-concepções erradas tornem-se um obstáculo à compreensão de conceitos científicos.

As idéias de Cho (1985) são muito pertinentes em relação à Genética, pois vivemos em um mundo que discute a regulamentação do uso de células-tronco e organismos geneticamente modificados, os transgênicos; questões genéticas são abordadas freqüentemente pela mídia, convivemos, de maneira mais próxima ou não, com indivíduos portadores de anomalias genéticas e, dessa maneira, a população vai construindo seus conceitos a respeito do assunto. Este público, que já apresenta préconcepções sobre o assunto, ao se deparar, na escola, com uma abordagem científica, têm dificuldade para abandonar as idéias do senso comum e estas se tornam obstáculos à compreensão dos conceitos.

A Genética é tida como a área da Biologia de mais difícil compreensão para estudantes do Ensino Médio (Bahar; Johnstone; Hansell, 1999) e do Ensino Superior (Johnstone; Mahmound, 1980), e também para professores de Ensino Médio (Finley; Stewart; Yarroch, 1982). Diversos estudos têm sido feitos na tentativa de averiguar a origem dos erros conceituais e os motivos dos estudantes apresentarem tantas dificuldades na resolução de problemas de Genética (Cho, 1985).

Law e Lee (2004) afirmam que a maioria das pessoas reconhece nos pais a fonte das características hereditárias, no entanto, desconhecem a natureza e os mecanismos da herança. Para Cho (1985), os erros conceituais mais comuns relacionados à meiose e à transmissão de características hereditárias são: as relações entre separação cromossômica e replicação do DNA, entre par de alelos e expressão das características, e entre movimento cromossômico e transmissão das características. Ayuso e col. (1996) apontam para as dificuldades na resolução de 
problemas de Genética. Mahadeva e Randerson (1982) destacam que outro conceito que é, geralmente, compreendido de maneira incorreta é o de mutação.

Tolman (1982) acredita que a dificuldade em relacionar os conceitos de meiose e de transmissão de características hereditárias vem da seqüência em que estes tópicos são apresentados nos livros de Biologia. A maioria dos livros analisados pelo autor aborda meiose e Genética em capítulos separados, sendo que o capítulo de meiose vem antes da Genética mendeliana. Considerando que a Genética mendeliana estuda a transmissão das características entre os descendentes e a meiose aborda a separação dos alelos durante a reprodução sexual, o autor sugere que ambos os conceitos devam ser tratados num único capítulo e que durante a discussão da meiose já se incluam termos associados à Genética, como por exemplo, dominante e recessivo, homozigótico e heterozigótico, genótipo e fenótipo.

Em relação às relações entre separação cromossômica, mesmo na mitose ou meiose, e replicação do DNA, Longdem (1982) sugere que o erro conceitual ocorra pelo fato de os estudantes não relacionarem a divisão cromossômica com a replicação do DNA, o que torna confuso o termo cromátide. No caso da relação entre par de alelos e expressão das características, Tolman (1982) afirma que o erro conceitual ocorre, porque os estudantes não relacionam alelos, homozigótico ou heterozigótico com características dominantes e recessivas. E, finalmente, com relação ao movimento cromossômico e transmissão das características, o autor acredita que o erro ocorra pelo fato de os estudantes entenderem mal a relação entre um par de alelos e o movimento dos cromossomos na meiose.

Slack e Stewart (1990) destacam que muitas das dificuldades que os estudantes apresentam para resolver, significativamente, problemas de Genética derivam de não conhecerem e nem compreenderem a natureza do processo. Para Ayuso e Banet (1996), é comum os estudantes obterem êxito na resolução de problemas, no entanto, estes não requerem que se compreendam os conceitos ou processos implícitos nos mesmos; trata-se de exercícios de resolução mecânica e aplicação de algoritmos.

Apesar de alguns estudantes compreenderem os conceitos isolados, eles não os relacionam (Fisher, 1983; Stewart, 1982). Os estudantes encontram dificuldades para relacionar os conceitos de alelo, gene, cromossomo, características, gametas, 
zigoto, dominante, recessivo, heterozigótico e homozigótico (Stewart, 1982). Esta lacuna na compreensão das relações entre os conceitos impede o desenvolvimento de conceitos mais elaborados como a evolução (Deadman; Kelly, 1978).

Com relação ao conceito de mutação, Mahadeva e Randerson (1982) relatam que os livros didáticos abordam as mutações como sendo raras, prejudiciais e recessivas. Os autores recomendam que as mutações sejam abordadas de maneira que os estudantes compreendam que são mudanças na molécula de DNA e que a expressão de uma mutação como rara, recessiva e prejudicial depende do ambiente e da época que este organismo vive. Cho (1985) afirma que o uso de conceitos incorretos e ambíguos nos livros didáticos pode resultar em dificuldades na aprendizagem da Genética.

Em um estudo feito simultaneamente na Inglaterra e na Alemanha, Lewis e Kattmann (2004) concluíram que, ao se trabalhar o conceito de gene, não se trata apenas de um processo de mudança conceitual em que as pré-concepções são abandonadas e substituídas por uma explicação científica, mas, ao invés disso, um processo evolutivo de assimilação e apreensão conceitual em que as concepções prévias são conciliadas com a nova concepção. A conclusão a que Lewis chegou pode ser ampliada para os demais conceitos abordados em Genética, pois trata-se de uma nova maneira de se pensar a mudança conceitual, em que não há o intuito de substituir o conceito prévio e sim conciliá-lo com o científico. Talvez dessa maneira os estudantes passem a ver mais sentido na aprendizagem escolar.

Banet e Ayuso (2000) afirmam que as estratégias de ensino tradicionais têm pouco efeito na aquisição conceitual dos estudantes. Vários estudos sugerem que se modifiquem as práticas pedagógicas por meio de novas estratégias de ensino. Nesta linha de raciocínio, um recurso recomendado para o ensino de Genética são os modelos e analogias. Duit (1991), afirma que o uso de modelos e analogias pode ser uma ferramenta muito útil no ensino e na aprendizagem de conceitos científicos considerados difíceis. $\mathrm{O}$ autor esclarece que as analogias representam comparações do conceito abordado com situações similares ou com algum objeto conhecido pelos estudantes. Para Shapiro (1985), as analogias devem tornar a nova informação mais concreta e mais acessível à imaginação do estudante. Para o autor, as analogias são de essencial importância na mudança conceitual, sendo que deve auxiliar a 
reestruturar a memória existente e preparar para a aquisição da nova informação; elas possibilitam que o estudante construa seu próprio conhecimento à medida que relaciona o novo conceito, geralmente abstrato, com a analogia.

\section{I.3 Teoria da Aprendizagem Significativa}

Moreira (1999) distingue três tipos de aprendizagem: a cognitiva, a afetiva e a psicomotora. A aprendizagem cognitiva é aquela que resulta no armazenamento organizado de informações na mente do ser que aprende, sendo esse complexo organizado conhecido como estrutura cognitiva.A aprendizagem afetiva resulta de sinais internos ao indivíduo e pode ser identificada com experiências tais como prazer e dor, satisfação ou descontentamento, alegria ou ansiedade. Para o autor, algumas experiências afetivas acompanham as experiências cognitivas. A aprendizagem psicomotora envolve respostas musculares adquiridas por meio de treino e prática, mas alguma aprendizagem cognitiva é geralmente importante na aquisição de habilidades psicomotoras.

A teoria da aprendizagem significativa de David Ausubel focaliza primordialmente a aprendizagem cognitiva. Para ele, aprendizagem significa organização e integração do material na estrutura cognitiva do aprendiz. Ele se baseia na premissa de que existe uma estrutura na qual essa organização e integração se processam; é a estrutura cognitiva, entendida como o conteúdo total de idéias de um certo indivíduo e sua organização, ou o conteúdo e a organização de suas idéias em uma área particular de conhecimentos. A estrutura cognitiva é o complexo por meio do qual se adquire e se utiliza o conhecimento.

O conceito central da teoria de Ausubel é o de aprendizagem significativa, que consiste em um processo por meio do qual uma nova informação relaciona-se com um aspecto especificamente relevante da estrutura de conhecimentos do indivíduo. Assim, a aprendizagem significativa envolve a interação da nova informação com uma estrutura de conhecimento específica já existente na estrutura cognitiva do indivíduo, a qual Ausubel define como conceito facilitador. A aprendizagem significativa ocorre quando a nova informação ancora-se em conceitos ou proposições relevantes, preexistentes na estrutura cognitiva do aprendiz. Ausubel 
vê o armazenamento de informações no cérebro humano como sendo organizado, formando uma hierarquia conceitual, na qual elementos mais específicos de conhecimento são ligados e assimilados a conceitos mais gerais, mais inclusivos. Estrutura cognitiva significa, portanto, uma estrutura hierárquica de conceitos que são representações de experiências sensoriais do indivíduo.

Contrastando com a aprendizagem significativa, Ausubel define aprendizagem mecânica como sendo a aprendizagem de novas informações com pouca ou nenhuma interação com conceitos relevantes existentes na estrutura cognitiva. Nesse caso, a nova informação é armazenada de maneira arbitrária. Não há interação entre a nova informação e aquela já armazenada. $\mathrm{O}$ conhecimento assim adquirido, fica arbitrariamente distribuído na estrutura cognitiva, sem ligar-se a conceitos facilitadores específicos.

Segundo Ausubel (1980), “a essência do processo de aprendizagem significativa é que as idéias simbolicamente expressas sejam relacionadas de maneira substantiva e não-arbitrária ao que o aprendiz já sabe, ou seja, a algum aspecto da sua estrutura cognitiva especificamente relevante para a aprendizagem dessas idéias. Este aspecto especificamente relevante pode ser, por exemplo, uma imagem, um símbolo, um conceito, uma proposição, já significativo".Portanto, uma das condições para a ocorrência da aprendizagem significativa é que o conceito a ser aprendido possa ser relacionado à estrutura cognitiva do aprendiz, de maneira não-arbitrária e não-literal. Um conceito com essa característica é dito potencialmente significativo. Esta condição implica não só que o conceito seja suficientemente não-arbitrário em si, de modo que possa ser aprendido, mas também que o aprendiz tenha disponível em sua estrutura cognitiva os facilitadores adequados.

Outra condição é que o aprendiz manifeste uma disposição para relacionar de maneira substantiva e não-arbitrária o novo conceito, potencialmente significativo, à sua estrutura cognitiva. De maneira recíproca, independentemente de quão disposto para aprender estiver o indivíduo, nem o processo nem o produto da aprendizagem serão significativos, se o material não for potencialmente significativo.

De acordo com Ausubel, a compreensão genuína de um conceito ou proposição implica a posse de significados claros, precisos, diferenciados e transferíveis. Para verificar se houve aprendizagem significativa de um determinado 
conceito, Ausubel propõe que a melhor maneira de evitar a "simulação da aprendizagem significativa" é formular questões e problemas de uma maneira nova e não-familiar, que requeira máxima transformação do conhecimento adquirido.

Em 1977 a teoria da aprendizagem significativa de Ausubel foi ampliada por Joseph Novak, que considera a educação como um conjunto de experiências não somente cognitivas, mas também afetivas e psicomotoras, que contribuem para o engrandecimento total do indivíduo (Moreira, 1999). Para Novak, uma teoria da educação deve ajudar a explicar como se pode melhorar as maneiras pelas quais os seres humanos pensam, sentem e fazem. Segundo ele, qualquer evento é uma ação de troca de significados e sentimentos entre o aprendiz e o professor, ou seja, um evento educativo está sempre acompanhado de uma experiência afetiva.

\section{I.4 Teoria das Inteligências Múltiplas}

Para Gama (2000), as pesquisas mais recentes em desenvolvimento cognitivo e neuropsicologia sugerem que as habilidades cognitivas são bem mais diferenciadas e mais específicas do que se acreditava (Gardner, 1985).

Howard Gardner, psicólogo da Universidade de Harvard, baseou-se nestas pesquisas para questionar a visão tradicional da inteligência, que enfatiza apenas as habilidades lingüística e lógico-matemática. Segundo Gardner (1987), todos os indivíduos normais são capazes de uma atuação em pelo menos sete diferentes áreas intelectuais, que, até certo ponto, são independentes entre si. Ele sugere que não existem habilidades gerais, duvida da possibilidade de se medir a inteligência por meio de testes de papel e lápis e dá grande importância a diferentes atuações valorizadas em culturas diversas. Finalmente, ele define inteligência como a habilidade para resolver problemas ou criar produtos que sejam significativos em um ou mais ambientes culturais (Gama, 2000).

Gama (2000) afirma que a Teoria das Inteligências Múltiplas de Howard Gardner (1989) é uma alternativa para o conceito de inteligência como uma capacidade inata, geral e única, que permite aos indivíduos uma performance, maior ou menor, em qualquer área de atuação. Gardner identificou as inteligências lingüística, lógico-matemática, espacial, musical, cinestésica, interpessoal e 
intrapessoal. Afirma que essas competências intelectuais são relativamente independentes, têm sua origem e limites genéticos próprios e substratos neuroanatômicos específicos e dispõem de processos cognitivos próprios. Segundo ele, os seres humanos dispõem de graus variados de cada uma das inteligências e maneiras diferentes com que elas se combinam e organizam e se utilizam dessas capacidades intelectuais para resolver problemas e criar produtos. Gardner ressalta que, embora estas inteligências sejam, até certo ponto, independentes uma das outras, elas raramente funcionam isoladamente. Embora algumas ocupações exemplifiquem uma inteligência, na maioria dos casos as ocupações ilustram bem a necessidade de uma combinação de inteligências. Por exemplo, um cirurgião necessita da acuidade da inteligência espacial combinada com a destreza da sinestésica (Gardner, 1985).

No que se refere à educação centrada no aprendiz, Gardner levanta dois pontos importantes que sugerem a necessidade da individualização. O primeiro diz respeito ao fato de que, se os indivíduos têm perfis cognitivos tão diferentes uns dos outros, as escolas deveriam, ao invés de oferecer uma educação padronizada, tentar garantir que cada um recebesse a educação que favorecesse o seu potencial individual. O segundo ponto levantado por Gardner é igualmente importante: enquanto na Idade Média um indivíduo podia pretender tomar posse de todo o saber universal, hoje em dia essa tarefa é totalmente impossível, sendo mesmo bastante difícil o domínio de um só campo do saber (Gama, 2000). Assim, se há a necessidade de se limitar a ênfase e a variedade de conteúdos, que essa limitação seja da escolha de cada um, favorecendo o perfil intelectual individual.

Diante do marco teórico aqui apresentado, o presente trabalho de pesquisa analisa o conhecimento de alguns conceitos fundamentais de Genética, Biologia Molecular e Biologia Celular apresentados por estudantes em fase final dos Cursos Superiores em Ciências Biológicas. 


\section{OBJETIVOS}

\section{Objetivo Geral}

O Objetivo geral desse trabalho de pesquisa foi analisar o compreensão de conceitos fundamentais de Genética, Biologia Molecular e Biologia Celular apresentado por graduandos do último ano de Cursos Superiores de Ciências Biológicas, tendo por base os resultados do Exame Nacional de Cursos de Biologia de 2002.

\section{Objetivos Específicos}

No contexto do conhecimento de conceitos de Genética que os graduandos em Ciências Biológicas apresentam, tivemos os seguintes objetivos com a realização dessa pesquisa:

a) Analisar as concepções de conceitos fundamentais de Genética e de disciplinas correlatas apresentados por estudantes do último ano de Cursos Superiores de Ciências Biológicas.

b) Inferir as possíveis explicações para as compreensões inadequadas dos conceitos básicos de Genética e disciplinas correlatas.

c) Discutir as possíveis causas das dificuldades detectadas nesses estudantes. 


\section{MÉTODOS}

As estratégias utilizadas na realização do presente trabalho são discriminadas a seguir.

a) Seleção das questões do Exame Nacional de Cursos de Biologia de 2002 (ENC-BIO/2002)

b) Análise do relatório do ENC-BIO/2002 expedido pelo MEC.

c) Pesquisa do conteúdo abordado em cada questão em livros didáticos utilizados como referência no Ensino Superior.

d) Aplicação de questionários com as questões do ENC-BIO/2002 selecionadas para essa pesquisa.

e) Realização de entrevistas semi-estruturadas com estudantes do último ano de cursos de Ciências Biológicas.

f) Análise dos resultados apresentados pelo relatório do MEC e das entrevistas realizadas.

\section{Seleção das questões do ENC-BIO/2002}

O Exame Nacional de Cursos (ENC-Provão) foi um exame aplicado aos formandos no período de 1996 a 2003, com o objetivo de avaliar os cursos de graduação da Educação Superior, no que tange aos resultados do processo ensinoaprendizagem. Os cursos de Ciências Biológicas, foram avaliados pelo ENC de 2000 a 2003.

De acordo com a portaria $\mathrm{n}^{\mathrm{o}}$ 296, de 30/01/2002, publicada no Diário Oficial de 01/02/2002, o ENC para Ciências Biológicas teve por objetivos "avaliar a formação do biólogo com base nos conhecimentos, competências e habilidades desenvolvidos durante a graduação e necessários ao exercício profissional, verificar o desempenho das Instituições de Ensino Superior na formação dos biólogos e estimular ações que visem ao aperfeiçoamento do processo pedagógico na formação de biólogos". 
A prova foi constituída por quarenta questões de múltipla escolha e cinco questões discursivas que abordaram conteúdos de Biologia considerados fundamentais à formação do biólogo, segundo as Diretrizes Curriculares Nacionais para os cursos de Ciências Biológicas. Além dessas questões, fez parte do exame um questionário pesquisa, com oitenta e cinco questões, que foi enviado previamente aos graduandos e cujo cartão-resposta era entregue, já preenchido, no dia da prova. As respostas a essas questões permitiram traçar um perfil do graduando. Também fez parte da prova, um questionário com onze questões a respeito das impressões sobre a prova.

O Exame Nacional de Cursos foi escolhido por representar, na época, o teste mais significativo e representativo do Ensino Superior no país. Segundo dados do Ministério da Educação e Cultura, nas vinte e quatro áreas avaliadas em 2002, participaram cerca de 386 mil estudantes de 4,7 mil cursos. No que diz respeito aos cursos de Ciências Biológicas participaram do exame no ano de 2002, 12.376 estudantes provenientes de 270 cursos de todo o país. O Exame foi elaborado de acordo com as Diretrizes Curriculares Nacionais para os cursos de Ciências Biológicas e, sendo assim, teve como objetivo avaliar a formação do biólogo com base nos conhecimentos, competências e habilidades necessárias ao exercício profissional desenvolvidos durante a graduação.

Dentre as quarenta questões de múltipla escolha, foram consideradas neste estudo somente as oito primeiras (Anexo1), referentes aos conteúdos de Genética, Biologia Molecular e Biologia Celular.

\section{Análise do relatório expedido pelo MEC}

Este trabalho foi iniciado com uma pesquisa da análise dos resultados obtidos pelos estudantes que participaram do Exame Nacional de Cursos (Provão) de Biologia-2002 (ENC-BIO/2002), tendo como documento básico o caderno de questões do estudante e o relatório expedido pelo MEC. A escolha do material se deu pelo fato de que esses documentos nos trazem todas as questões acompanhadas dos respectivos índices de facilidade e de discriminação e o percentual de resposta de cada alternativa. 
As questões foram analisadas uma a uma levantando-se a percentagem de acertos e a alternativa mais assinalada dentre as incorretas, conforme dados fornecidos pelo relatório do MEC. A análise da alternativa incorreta mais assinalada foi feita no sentido de investigar os prováveis motivos que induziram os estudantes ao erro. Verificamos também o índice de facilidade e de discriminação de cada questão.

\section{Pesquisa em livros didáticos}

O conteúdo abordado em cada uma das questões foi pesquisado nos livros Genética Moderna de Griffthis e col. (2001) e Biology de Campbell e col (1999) com o intuito de verificar como os autores abordam os conceitos pesquisados, na tentativa de estabelecer possíveis motivos para os equívocos nas respostas assinaladas. Optamos por pesquisar o conteúdo nesses dois livros pelo fato de servirem como referência nos cursos superiores de Ciências Biológicas .

\section{Aplicação de questionários}

No sentido de nos aproximarmos dos estudantes do ensino superior e obtermos voluntários para a participação nas entrevistas, foi aplicado um questionário com as oito questões do ENC-BIO/2002 analisadas em setenta e dois estudantes do último ano do curso de Biologia (tabela 1).

Segundo Laville e Dionne (1999), o uso de questionários de múltipla escolha permite alcançar rápida e simultaneamente um grande número de pessoas, além de assegurar, por meio da uniformização, que cada pessoa veja as questões formuladas da mesma maneira.

Os estudantes que responderam aos questionários eram provenientes de três diferentes Instituições de Ensino Superior do setor privado, sendo estes oriundos de horários noturno e vespertino, conforme a disponibilidade do professor.

A seleção destas escolas foi feita conforme a receptividade dos coordenadores de curso das Instituições e/ou disponibilidade dos estudantes responderem aos questionários. 
Os estudantes receberam uma breve explicação da pesquisa e durante cerca de trinta minutos concluíram o preenchimento do questionário.

\begin{tabular}{|c|c|c|}
\hline Instituição & Período & $\mathrm{N}^{\circ}$ de estudantes \\
\hline A & Noturno & 24 \\
\hline B & Noturno & 27 \\
\hline C & Vespertino & 21 \\
\hline
\end{tabular}

Tabela 1 - Número de alunos que responderam o questionário, por Instituição.

As respostas foram obtidas de estudantes que se dispuseram a aceitar as condições da pesquisa e autorizaram a utilização dos dados conforme anexo 2 (parte I).

A tabulação foi realizada de acordo com os acertos propostos pelo gabarito e as questões discutidas uma a uma com referência aos resultados disponibilizados pelo MEC.

\section{Realização de entrevistas}

No final do questionário respondido espontaneamente pelos estudantes, havia um formulário para ser preenchido por aqueles que tivessem disponibilidade e interesse em participar das entrevistas. (anexo 2, parte II).

Decidimos por utilizar esse método de coleta de dados, pois os resultados obtidos pelos questionários, como já era de se esperar, deveriam estar de acordo com os dados fornecidos pelo relatório do MEC. Além disso, acreditávamos que o uso de entrevistas pudesse fornecer dados que complementassem os questionários. Segundo Ludke e André (1986) a utilização de entrevistas pode permitir um aprofundamento e esclarecimento de pontos levantados por outras técnicas como a de questionários de múltipla escolha, por exemplo.

Inicialmente, no primeiro momento entrevistamos nove estudantes de duas das Instituições onde os questionários foram aplicados (A e C). Não obtivemos amostragem da terceira Instituição (B) por dificuldades em agendar as entrevistas com os estudantes, devido ao período letivo, pois só conseguimos autorização para 
aplicar os questionários na semana de provas finais, sendo assim, a maioria dos estudantes não tinha disponibilidade devido às provas e, posteriormente, por já estarem em férias.

Em um segundo momento, sentimos a necessidade de realizar mais entrevistas para podermos aumentar a amostra e fazer uma análise mais detalhada do assunto. Nesta etapa não utilizamos os questionários como estratégia de aproximação. Foi feito contato prévio com os coordenadores de cursos e professores e obtivemos autorização para uma conversa com os estudantes.

No início da aula explicamos rapidamente os objetivos da pesquisa e a importância da realização das entrevistas. Os estudantes que se dispuseram a participar preencheram o formulário (anexo 2, parte II) e, tanto os alunos que responderam os questionários quanto estes últimos foram contatados por telefone para marcar data, horário e local que estariam disponíveis.

Foram realizadas um total de trinta e três entrevistas em três Instituições de Ensino Superior, sendo uma pública (D) e duas privadas (A e C) (tabela 2).

\begin{tabular}{|c|c|c|}
\hline Instituição & Período & $\mathrm{N}^{\circ}$ de alunos \\
\hline $\mathrm{A}$ & Noturno & 06 \\
\hline $\mathrm{C}$ & Vespertino & 13 \\
\hline $\mathrm{D}$ & Diurno & 14 \\
\hline
\end{tabular}

Tabela 2 - Número de entrevistas realizadas por Instituição

O método utilizado foi o de entrevistas semi-estruturadas e gravadas, mediante autorização. Estas entrevistas foram posteriormente transcritas na íntegra. O objetivo da transcrição integral das entrevistas foi auxiliar a discussão pertinente ao exposto pelos estudantes além de permitir um relato fiel dos conceitos tidos como corretos pelos entrevistados. Durante a entrevista, os nove estudantes entrevistados que responderam aos questionários puderam rever seus questionários. As questões elaboradas na entrevista solicitavam que os estudantes expusessem os motivos pelos quais assinalaram alternativas incorretas, julgando-as "a priori" corretas, além de serem interrogados sobre a concepção de conceitos básicos de Genética. Por meio desta ação, buscou-se identificar equívocos conceituais que induziram aos erros. Os 
estudantes que não responderam os questionários foram apenas interrogados sobre suas concepções a respeito de alguns conceitos tidos como básicos na formação do biólogo (Anexo 3). 


\section{RESULTADOS}

\section{Análise das questões do ENC-Biologia-2002}

A primeira etapa do trabalho foi realizar um levantamento dos dados apresentados no relatório elaborado pela comissão responsável pela análise dos resultados obtidos pelos 12.376 estudantes que participaram do Exame Nacional de Cursos de Biologia no ano de 2002. Utilizamos o provão pelo fato de, na época, representar o exame mais significativo de avaliação do Ensino Superior, além de ter sido elaborado de acordo com as Diretrizes Curriculares para o Ensino Superior. Sendo assim, as questões abordadas pelo Exame foram elaboradas tendo em vista as habilidades e competências necessárias para a formação de biólogos.

Verificamos os índices de discriminação e de facilidade de cada uma das questões fornecidos pelo relatório do MEC, que serão analisados no item 1.1 de cada questão.

$\mathrm{O}$ índice de discriminação refere-se à diferença entre o percentual de acerto da faixa superior e o da faixa inferior. Segundo este índice, uma questão é considerada excelente, boa, média ou fraca, conforme o seu índice de discriminação seja maior ou igual a $40 \%$, esteja entre 30 e $39 \%$, entre $20 \%$ e $29 \%$ e inferior ou igual a $19 \%$, respectivamente.

\begin{tabular}{|l|l|}
\hline Índice & Classificação \\
\hline$\geq 0,40$ & Excelente \\
\hline 0,30 a 0,39 & Bom \\
\hline 0,20 a 0,29 & Médio \\
\hline$\leq 0,19$ & Fraco \\
\hline
\end{tabular}

Tabela 3 - índice de discriminação

$O$ índice de facilidade refere-se aos percentuais de acerto geral em cada questão. Segundo este índice, uma questão é considerada muito fácil, fácil, média, difícil ou muito difícil, conforme seu índice de facilidade seja maior do que $85 \%$ 
esteja entre $61 \%$ e $85 \%$, entre $41 \%$ a $60 \%$ entre $16 \%$ a $40 \%$ e menor que $16 \%$, respectivamente.

\begin{tabular}{|l|l|}
\hline Índice & Classificação \\
\hline$>0,85$ & Muito Fácil \\
\hline 0,61 a 0,85 & Fácil \\
\hline 0,41 a 0,60 & Médio \\
\hline 0,16 a 0,40 & Difícil \\
\hline$<0,16$ & Muito Difícil \\
\hline
\end{tabular}

Tabela 4 - Classificação do índice de facilidade.

Uma outra preocupação foi verificar se livros didáticos apresentavam o conteúdo tratado nas oito questões estudadas e, caso o conteúdo fosse abordado, verificar, também, a maneira como tal assunto é apresentado. Por isso, realizamos uma leitura minuciosa dos livros de Griffiths e colaboradores e de Campbell e colaboradores para investigar se os conceitos eram tratados e como isso era feito.

\section{I.1 Questões}

Decidimos analisar o resultado das oito primeiras questões do ENC-BIO/2002 por abordarem conceitos de Genética, Biologia Molecular e Biologia Celular. A resposta correta de acordo com o gabarito expedido pelo relatório do MEC apresenta-se destacada em negrito, tanto nos quadros quanto nas tabelas, em cada uma das oito questões. As tabelas foram elaboradas levando-se em consideração a classificação utilizada no relatório do MEC, geral, superior e inferior, que referemse, respectivamente, ao grupo total de estudantes, ao grupo que obteve os melhores resultados, com maiores índices de acertos, e ao grupo que obteve os piores resultados, com menores índices de acertos, respectivamente, da prova como um todo. 


\section{Questão 1 - Quadro I}

A anemia falciforme é uma doença hereditária com herança autossômica recessiva, que tem grande incidência nas populações africanas negras. Os indivíduos afetados são homozigóticos ( $\mathrm{HbS} / \mathrm{HbS})$ em relação a uma alteração na hemoglobina. Os indivíduos heterozigóticos $(\mathrm{HbA} / \mathrm{HbS})$ geralmente não manifestam os sintomas da doença e são denominados portadores do traço falcêmico. O pesquisador Vernon Ingram observou, em 1957, que a única diferença entre a hemoglobina mutante dos afetados e a hemoglobina normal é a presença do aminoácido valina em lugar do ácido glutâmico, na posição 6 em uma das cadeias da molécula.

1. Do ponto de vista histórico, é correto afirmar que o principal impacto da pesquisa de Ingram foi.
(A) decifrar o código genético.
(B) evidenciar a relação direta entre o RNA mensageiro e a cadeia de aminoácidos nas proteínas.
(C) comprovar que era possível seqüenciar as bases do DNA por meio dos aminoácidos.
(D) demonstrar que as mutações podem causar alterações nas cadeias polipeptídicas.

(E) verificar que as mutações causam alterações nas moléculas de RNA mensageiro. 
Percentual de respostas da questão 1 nas três categorias consideradas.

\begin{tabular}{lc|ccc|cc} 
& \% A & \% B & $\mathbf{\%} \mathbf{C}$ & $\mathbf{\%} \mathbf{D}$ & $\mathbf{\%} \mathbf{E}$ & $\mathbf{\%}$ Inv. \\
\hline Geral & 7,57 & 19,42 & 15,32 & $\mathbf{4 5 , 6 4}$ & 11,34 & 0,70 \\
Inferior & 13,31 & 20,51 & 19,96 & $\mathbf{2 8 , 3 2}$ & 16,28 & 1,62 \\
Superior & 2,72 & 18,00 & 8,54 & $\mathbf{6 4 , 7 7}$ & 5,79 & 0,18 \\
\hline
\end{tabular}

Tabela 4 - Percentual de respostas da questão 1.

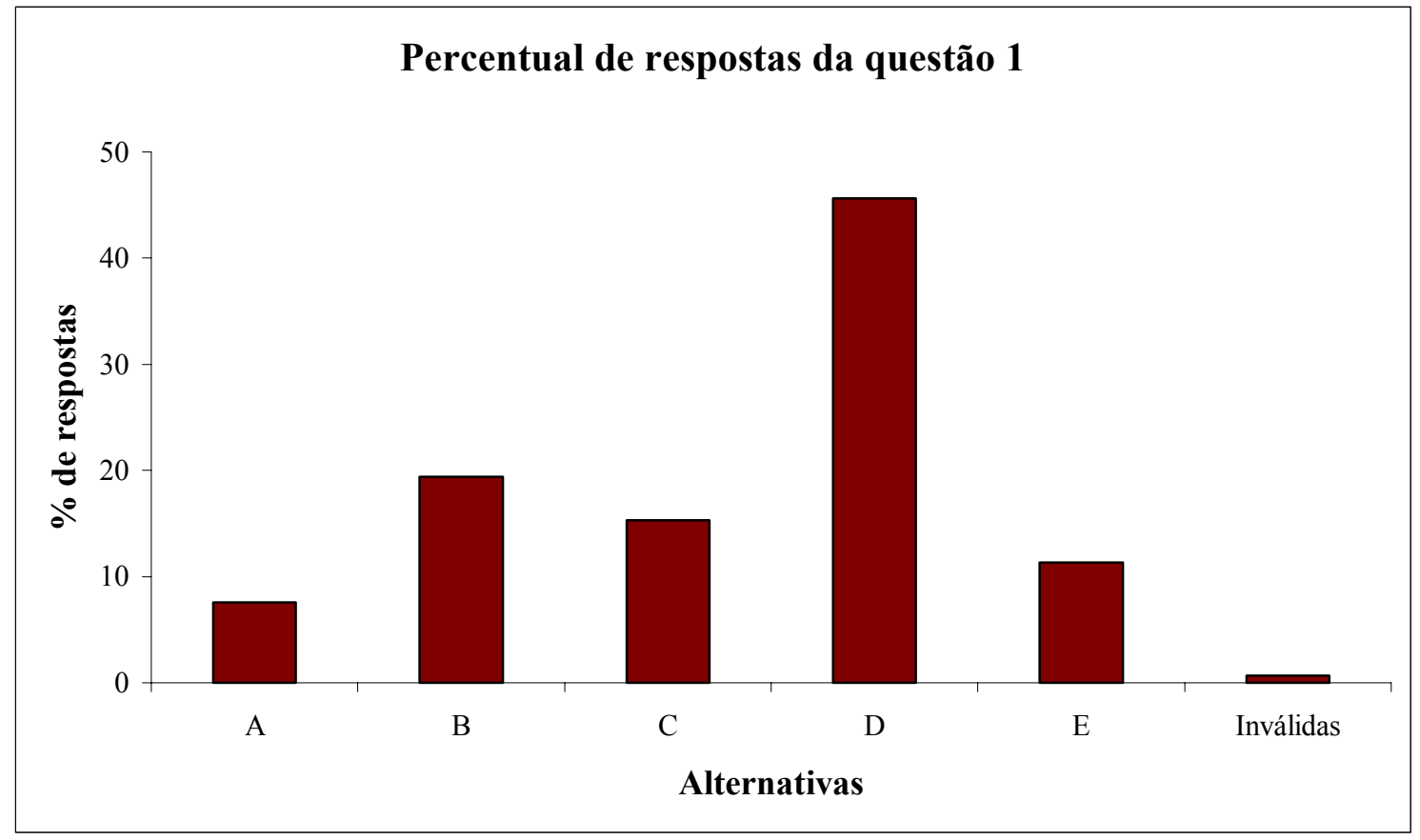

Gráfico 1 - Percentual de respostas da questão 1 


\section{1 - Análise Geral}

Trata-se de uma questão com bom índice de discriminação $(0,36)$, tendo o grupo superior um índice de $64,47 \%$ de acerto, enquanto que o inferior concentra apenas $28,32 \%$. De acordo com o índice de facilidade, a questão é considerada de grau médio $(0,45)$.

Das respostas incorretas, a que obteve maior porcentagem de escolha foi a alternativa "B", na qual $18,00 \%$ do grupo superior e $20,51 \%$ do grupo inferior a assinalaram.

\section{2 - Abordagem em livro-didático}

Em Griffths, 2001, o conceito de mutação e sua relação com a síntese de proteínas é tratado como se segue: "A anemia falciforme é uma doença genética causada por uma alteração mutacional bem caracterizada. Afetando aproximadamente $0,25 \%$ dos afro-americanos, a doença resulta de uma hemoglobina alterada, na qual o aminoácido valina substitui o ácido glutâmico na posição 6 da cadeia $\beta$ da globina... As mutações, alterações na seqüência do DNA de um gene, ocorrem espontaneamente na natureza. Uma vez que os alelos são formas de genes, as mutações, por definição, criam novos".

"Os alelos mutantes mais simples demonstram uma seqüência de DNA alterada em apenas uma posição no gene. Este alelo mutante é composto de uma seqüência normal de nucleotídeos, exceto na área da mudança, conhecida como sítio de mutação. Devido à maneira pela qual o código genético é lido durante a tradução, uma mutação que substitui um par de bases por outro afeta especificamente um aminoácido. Por causa da colinearidade entre o gene e a estrutura primária da proteína, as mutações nas seqüências de nucleotídeos no DNA alternam a cadeia de aminoácidos precisamente na mesma posição relativa. Uma alteração de um único nucleotídeo, em um códon, em um sítio funcional crucial na proteína (como o sítio ativo de uma enzima) pode resultar em uma substituição de um aminoácido que leva a uma função aberrante".

Em 1957 não se conhecia o RNAm. Neste ano, Crick lançou a idéia do dogma central, DNA $\rightarrow$ RNA $\rightarrow$ Proteína, mas não se conhecia código genético e 
nem se sabia como as proteínas eram sintetizadas na célula; a teoria um gene - um polipeptídio já estava consolidada, como se verifica no artigo publicado no periódico Nature em janeiro de 2003 por R. Olby: "Em 1957, Crick definiu a informação biológica como a seqüência de bases nos ácidos nucléicos e dos aminoácidos em proteínas, e propôs o dogma central, segundo o qual as informações são definidas dos ácidos nucléicos para as proteínas em uma única direção, do primeiro para o último”.(Olby, 2003)

\section{Questão 2 - Quadro II}

2. Dentre quatro populações pequenas e geograficamente próximas de descendentes de escravos africanos, em apenas uma foram detectados portadores do traço falcêmico. Uma vez que nenhuma das populações está sujeita a fluxo gênico, a observação pode ser explicada por

(A) taxas de recombinação diferentes em cada população.

(B) taxas de mutação constantes em cada população.

(C) deriva genética e migração.

(D) altas taxas de endogamia em cada população.

(E) diferentes genótipos fundadores em cada população e pequeno tamanho populacional.

\begin{tabular}{lc|ccccc} 
& \% A & \% B & \% C & \% D & \% E & \% Inv. \\
\hline Geral & 23,41 & 7,81 & 16,32 & 16,59 & $\mathbf{3 5 , 0 2}$ & 0,86 \\
Inferior & 26,68 & 11,99 & 23,29 & 10,08 & $\mathbf{2 6 , 1 1}$ & 1,85 \\
Superior & 15,13 & 3,52 & 8,22 & 23,47 & $\mathbf{4 9 , 3 6}$ & 0,30 \\
\hline
\end{tabular}

Percentual de respostas da questão 2 nas três categorias consideradas. 
Tabela 5 - Percentual de respostas da questão 2.

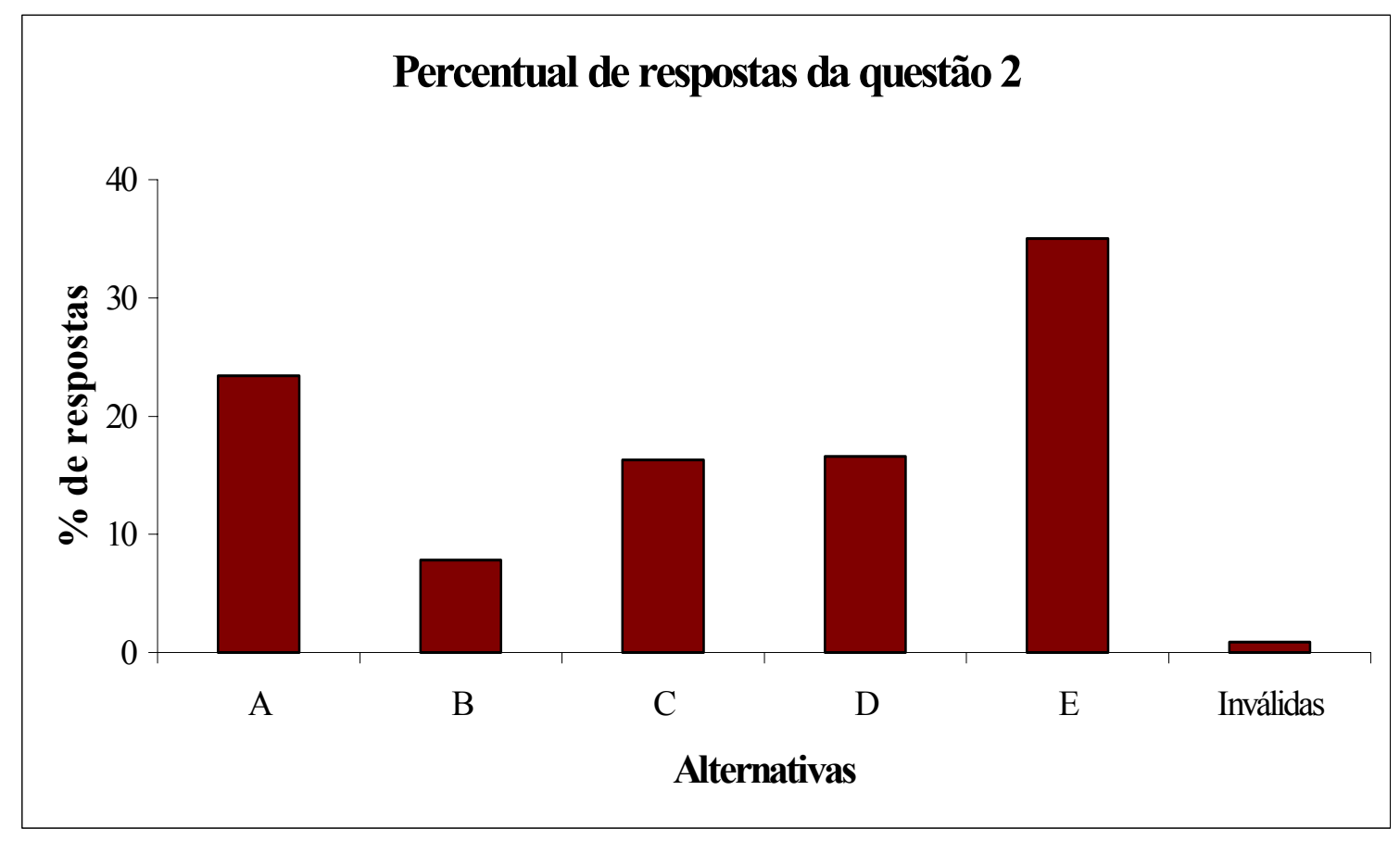

Gráfico 2 - Percentual de respostas da questão 2.

\section{1 - Análise Geral}

Trata-se de uma questão com índice de discriminação médio $(0,23)$, tendo o grupo superior um índice de $49,36 \%$ de acerto, enquanto que o inferior concentra apenas $26,11 \%$. De acordo com o índice de facilidade, esta é uma questão difícil $(0,35)$.

Das respostas incorretas, a que obteve maior porcentagem de escolha foi a alternativa "A", na qual $15,13 \%$ do grupo superior e $26,68 \%$ do grupo inferior a assinalaram.

Para responder corretamente a esta questão, é necessário que o estudante tenha domínio dos conceitos abordados e que seja capaz de relacioná-los à situação problema apresentada na questão. Se a aprendizagem foi mais mecânica do que significativa o estudante não será capaz de fazer a transposição dos conceitos para essa situação, caso ela não tenha sido explicitamente tratada em aula ou no livro didático. 
Comparando-se a alternativa correta (E) com a mais assinalada dentre as incorretas (A), pode-se constatar que os conceitos de taxas de recombinação e genótipos fundadores são pontos de dúvida dentre os estudantes.

A questão aborda os conceitos de recombinação, mutação, deriva genética, migração, endogamia e genótipos fundadores.

Acreditamos que esses conceitos não são do conhecimento dos estudantes. Eles podem até ter ouvido falar a respeito, porém tais conceitos não fazem parte de sua rede conceitual, pois geralmente, utilizam-se de conhecimentos do senso comum ou da definição etimológica das palavras para responder às questões.

\section{2 - Abordagem no livro didático}

Segundo Griffiths e colaboradores, 2001, “A variação hereditária é um elemento chave na genética. Dois processos são responsáveis pela variação genética, a recombinação e a mutação. A mutação é um importante recurso de mudança genética. Surgem novos alelos em todos os organismos, alguns espontaneamente, outros como resultado de exposição a agentes mutagênicos no ambiente. Estes novos alelos tornam-se a matéria-prima para o segundo nível de variação, efetuado pela recombinação. Como seu nome sugere, a recombinação é o processo pelo qual os alelos de genes diferentes se associam em novas combinações".

Na natureza, as mutações e recombinações fornecem as variações hereditárias que constituem a matéria-prima para a seleção natural agir... A reprodução aleatória com relação a um loco é comum, mas não é universal. Dois tipos de desvio da reprodução aleatória devem ser diferenciados. Primeiro, os indivíduos podem se reproduzir uns com os outros não aleatoriamente devido a seu grau de ancestrais comuns; isto é, seu grau de correlação genética. Se a reprodução entre parentes ocorrer mais comumente que ocorreria por puro acaso, então a população é endogâmica.

... Na endogamia, a conseqüencia para a estrutura da população é que há um aumento na homozigose acima do nível previsto pelo equilíbrio de Hardy-Weimberg. Se dois indivíduos são aparentados, eles têm pelo menos um ancestral comum. 
Assim, há alguma chance de que um alelo levado por um deles e um alelo levado pelo outro sejam ambos descendentes de uma molécula idêntica de DNA.

... Uma outra fonte de variação é a migração para uma população, vinda de outras populações com freqüências gênicas diferentes. A população mista resultante terá uma freqüência alélica que é um tanto intermediária entre seu valor original e a freqüência da população doadora.

...Uma população diferente, isolada da primeira, também sofre deriva genética aleatória, mas pode se tornar homozigota para o alelo A, enquanto a primeira população tornou-se homozigota para o alelo a. À medida que o tempo passa, as populações isoladas divergem uma da outra, cada uma perdendo a heterozigose... Uma forma de deriva genética ocorre quando um pequeno grupo se destaca de uma população maior para fundar uma nova colônia. Esta "deriva aguda", chamada efeito do fundador resulta de uma única geração de amostra, seguida de várias gerações durante as quais a população permanece pequena... O processo da deriva genética deve parecer familiar. $E^{\prime}$, de fato, um outro modo de ver o efeito da endogamia em populações pequenas. Seja visto como endogamia ou como amostragem aleatória de genes, o efeito é o mesmo. As populações não reproduzem exatamente suas constituições genéticas. Há um componente aleatório de mudança na freqüência gênica”. 


\section{Questão 3 - Quadro III}

Na revista Science de 14 de dezembro de 2001, um grupo de pesquisadores relatou a cura da anemia falciforme em camundongos, através da terapia gênica. A partir de um retrovírus modificado, a equipe construiu um vetor para a introdução do gene terapêutico. A estratégia do experimento baseou-se no fato de haver integração, ao genoma das células infectadas, de uma cópia do
(A) RNA viral, retrotranscrita em DNA.
(B) DNA viral, transcrita em RNA.
(C) RNA viral, retrotranscrita em RNA.
(D) RNA viral, embora ambos os ácidos nucléicos tenham sido introduzidos nas células.
(E) DNA viral, embora ambos os ácidos nucléicos tenham sido introduzidos nas células.

Percentual de respostas da questão 3 nas três categorias consideradas.

\begin{tabular}{lc|ccc|cc} 
& $\% \mathbf{A}$ & $\mathbf{\%} \mathbf{B}$ & $\mathbf{\%} \mathbf{C}$ & $\% \mathbf{D}$ & $\% \mathbf{E}$ & $\% \mathbf{I n v}$ \\
\hline Geral & $\mathbf{4 2 , 7 0}$ & 23,48 & 8,17 & 10,12 & 14,83 & 0,70 \\
Inferior & $\mathbf{2 0 , 0 4}$ & 28,40 & 9,85 & 15,69 & 24,39 & 1,64 \\
Superior & $\mathbf{7 3 , 2 5}$ & 12,44 & 4,94 & 3,64 & 5,56 & 0,18 \\
\hline
\end{tabular}

Tabela 6 - Percentual de respostas da questão 3. 


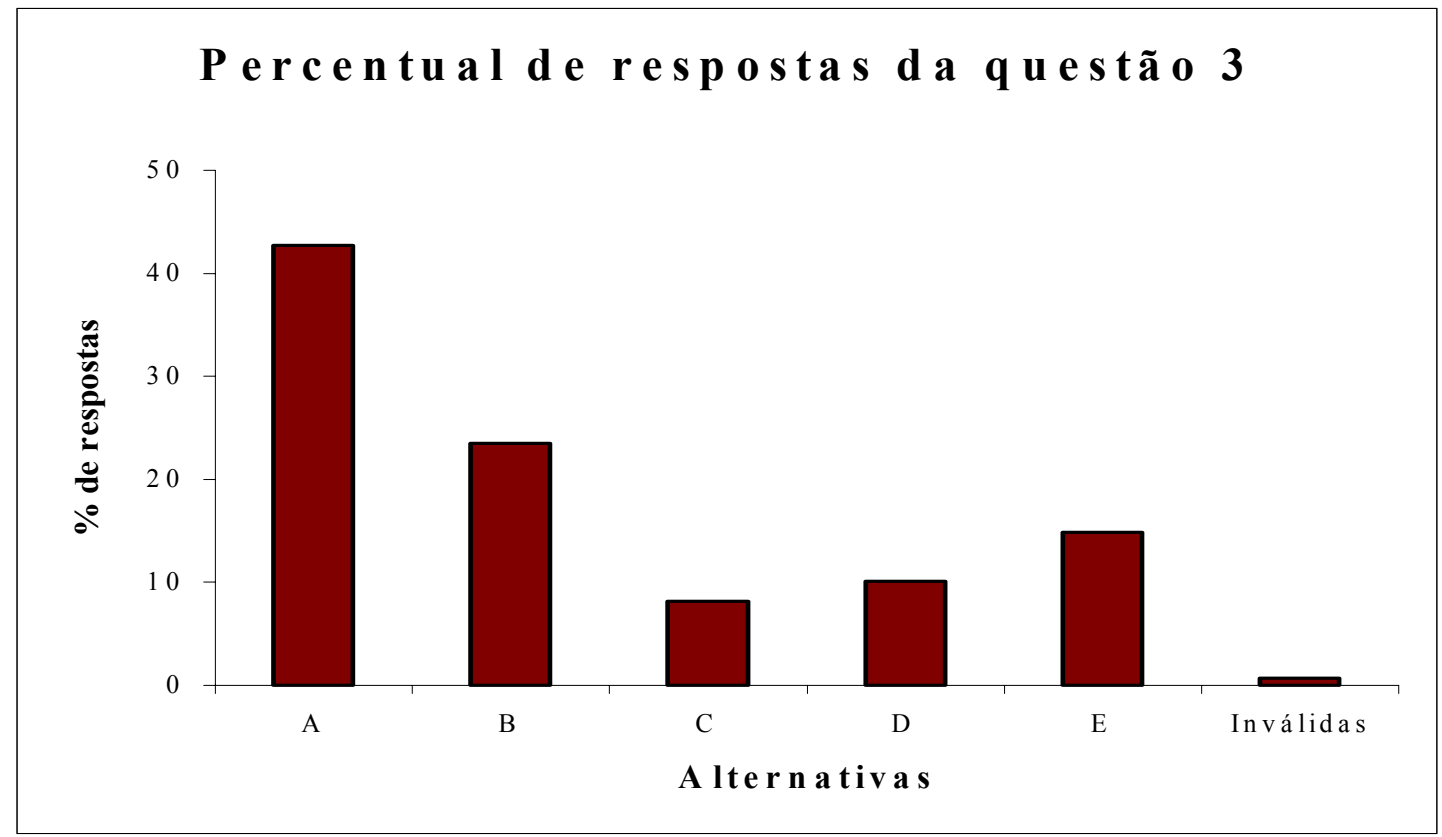

Gráfico 3 - Percentual de respostas da questão.

\section{1 - Análise Geral}

A questão apresenta um índice de discriminação excelente $(0,53)$, sendo que $73,25 \%$ dos estudantes do grupo superior e $20,04 \%$ do inferior a assinalaram, e índice de facilidade médio, 0,42 .

Das alternativas incorretas, a mais assinalada foi a "B", que foi a opção de $12,44 \%$ dos estudantes do grupo superior e $28,40 \%$ do grupo inferior. Analisando-se a alternativa "B", verifica-se que este grupo de estudantes desconhece o mecanismo de infecção do retrovírus, já que a mesma afirma que o DNA viral é transcrito em RNA.

A questão aborda os conhecimentos de Engenharia genética, como a modificação gênica pela introdução de genes em células.

Para que o estudante responda corretamente, são necessários conhecimentos sobre retrovírus modificado e vetor de introdução de genes. 


\section{2 - Abordagem no livro didático}

Segundo Griffiths, 2001, "Os retrovírus são vírus animais unifilamentares de $R N A$ que empregam um intermediário bifilamentar de DNA para replicação. $O R N A$ é copiado em DNA pela enzima transcriptase reversa".

\section{Questão 4 - Quadro IV}

4. O texto abaixo se refere às questões de número 4 a 6 .

João trabalha em uma confeitaria cujo proprietário é alemão. Todas as manhãs este deixa, sobre a mesa da cozinha, uma receita em português e os ingredientes de um bolo que João deve preparar. A receita original, escrita em alemão, fica guardada no escritório da confeitaria. Somente o patrão de João pode abrir o escritório e escrever, em português, a receita a ser utilizada naquele dia.

Para explicar a leigos o funcionamento de uma célula, fazendo uma analogia com o texto, o bolo, seus ingredientes, a receita em português e a receita em alemão corresponderão, respectivamente, a:

(A) aminoácido, nucleotídeos, DNA e RNA.

(B) nucleotídeo, aminoácidos, RNA e DNA.

(C) Polipeptídico, aminoácidos, RNA e DNA

(D) DNA, RNA, polipeptídio e aminoácido.

(E) DNA, aminoácidos, nucleotídeos e polipeptídios .

Percentual de respostas da questão 4 nas três categorias consideradas.

\begin{tabular}{lcccccc} 
& \% A & \% B & $\mathbf{\%} \mathbf{C}$ & $\mathbf{\%} \mathbf{D}$ & $\mathbf{\%} \mathbf{E}$ & $\%$ Inv. \\
\hline Geral & 16,61 & 19,43 & $\mathbf{3 6 , 3 7}$ & 14,86 & 12,10 & 0,63 \\
Inferior & 26,19 & 21,08 & $\mathbf{1 1 , 8 3}$ & 22,41 & 16,83 & 1,67 \\
Superior & 5,20 & 11,00 & $\mathbf{7 4 , 4 3}$ & 4,91 & 4,40 & 0,06 \\
\hline
\end{tabular}

Tabela 7 - Percentual de respostas da questão 4. 


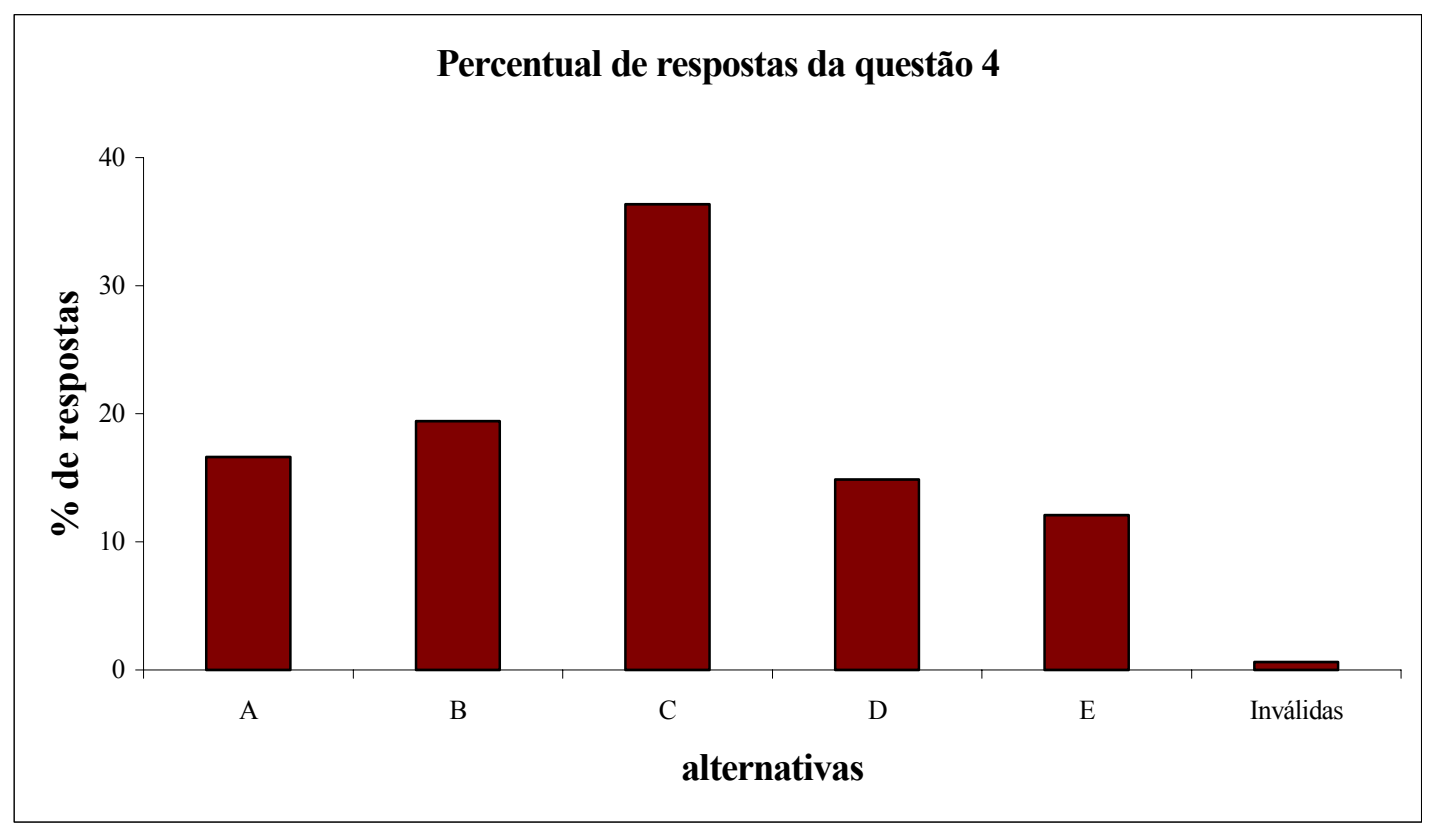

Gráfico 4 - Percentual de respostas da questão 4

\section{1 - Análise Geral}

Trata-se de uma questão com índice de discriminação excelente $(0,62)$, tendo o grupo superior um índice de $74,43 \%$ de acerto, enquanto que o inferior concentra apenas $11,83 \%$; o índice de facilidade foi de 0,36 , o que a classifica como sendo uma questão difícil.

Das respostas incorretas, a que obteve maior porcentagem de escolha foi a alternativa "B", na qual $11,00 \%$ do grupo superior e $21,08 \%$ do grupo inferior a assinalaram.

Para responder a esta questão com êxito, é necessário que o estudante seja capaz de relacionar os conceitos aprendidos à analogia feita no texto.

Comparando-se a alternativa correta $(\mathrm{C})$ com a mais assinalada dentre as incorretas (B), pode-se constatar que os conceitos de polipeptídio e nucleotídeo são pontos de dúvida dentre os estudantes, já que é o único termo que diferencia as duas alternativas.

A questão aborda os conceitos de nucleotídeo, polipeptídio, aminoácidos, RNA e DNA. 
Para que o estudante responda corretamente, são necessários conhecimentos sobre os processos de transcrição, tradução e síntese de proteínas. No livro texto, o assunto é tratado de maneira descritiva, não são explorados exemplos ou analogias.

\section{2 - Abordagem no livro didático}

Segundo Griffiths, 2001, “Os genes são compostos por uma macromolécula de dupla hélice, semelhante a uma espiral, chamada, ácido desoxirribonucléico, abreviado para DNA. O DNA, o material hereditário que passa de uma geração à seguinte, dita as propriedades inerentes de uma espécie. A informação codificada no DNA está sob a forma de seqüência de subunidades químicas chamadas nucleotídeos. Cada célula em um organismo contém, tipicamente, um ou dois grupos do complemento básico do DNA, chamado de um genoma. O genoma é constituído de uma ou mais moléculas de DNA extremamente longas agrupadas em estruturas denominadas cromossomos. Os genes são simplesmente as unidades funcionais do DNA cromossômico. Cada gene não só codifica a estrutura de algum produto celular, como também transporta consigo os" botões "de controle que determinam quando, onde e quando de cada produto será sintetizado. A maioria dos genes codifica produtos de proteína. As proteínas são as mais importantes determinantes das propriedades das células e organismos: quando observamos um organismo, o que vemos é uma proteína ou algo que foi feito a partir de uma proteína. A maneira pela qual os genes codificam as proteínas é indireta e envolve muitas etapas. A primeira é copiar (transcrever) a informação codificada no DNA do gene como uma molécula relacionada, porém unifilamentar, chamada $\mathbf{R N A}$ mensageiro. A seguir a informação do RNA mensageiro é traduzida (decodificada) em uma cadeia de aminoácidos denominada polipeptídio. Os polipeptídios, por si sós ou por meio da agregação a outros polipeptídios e constituintes celulares, formam as proteínas funcionais da célula. Como as propriedades celulares determinam as propriedades de um organismo, existe um elo direto entre os genes e a estrutura e função de um organismo." 


\section{Questão 5 - Quadro V}

5. Continuando a analogia, o escritório, a cozinha e João corresponderão, respectivamente, aos seguintes componentes de uma célula de eucarioto:
(A) citoplasma, núcleo e cromossomo.
(B) núcleo, citoplasma e ribossomo.
(C) citoplasma, núcleo e membrana nuclear,
(D) núcleo, citoplasma e cromossomo.
(E) cromossomo, membrana nuclear e citoplasma.

Percentual de respostas da questão 5 nas três categorias consideradas

\begin{tabular}{|c|c|c|c|c|c|c|}
\hline & $\% \mathrm{~A}$ & $\% B$ & $\% C$ & $\% D$ & $\% E$ & $\% \operatorname{Inv}$ \\
\hline Geral & 16,98 & 47,60 & 10,49 & 18,38 & 5,87 & 0,67 \\
\hline Inferior & 24,13 & 17,61 & 21,65 & 24,36 & 10,53 & 1,72 \\
\hline Superior & 4,97 & 85,93 & 0,74 & 6,68 & 1,51 & 0,18 \\
\hline
\end{tabular}

Tabela 8 - Percentual de respostas da questão 5. 


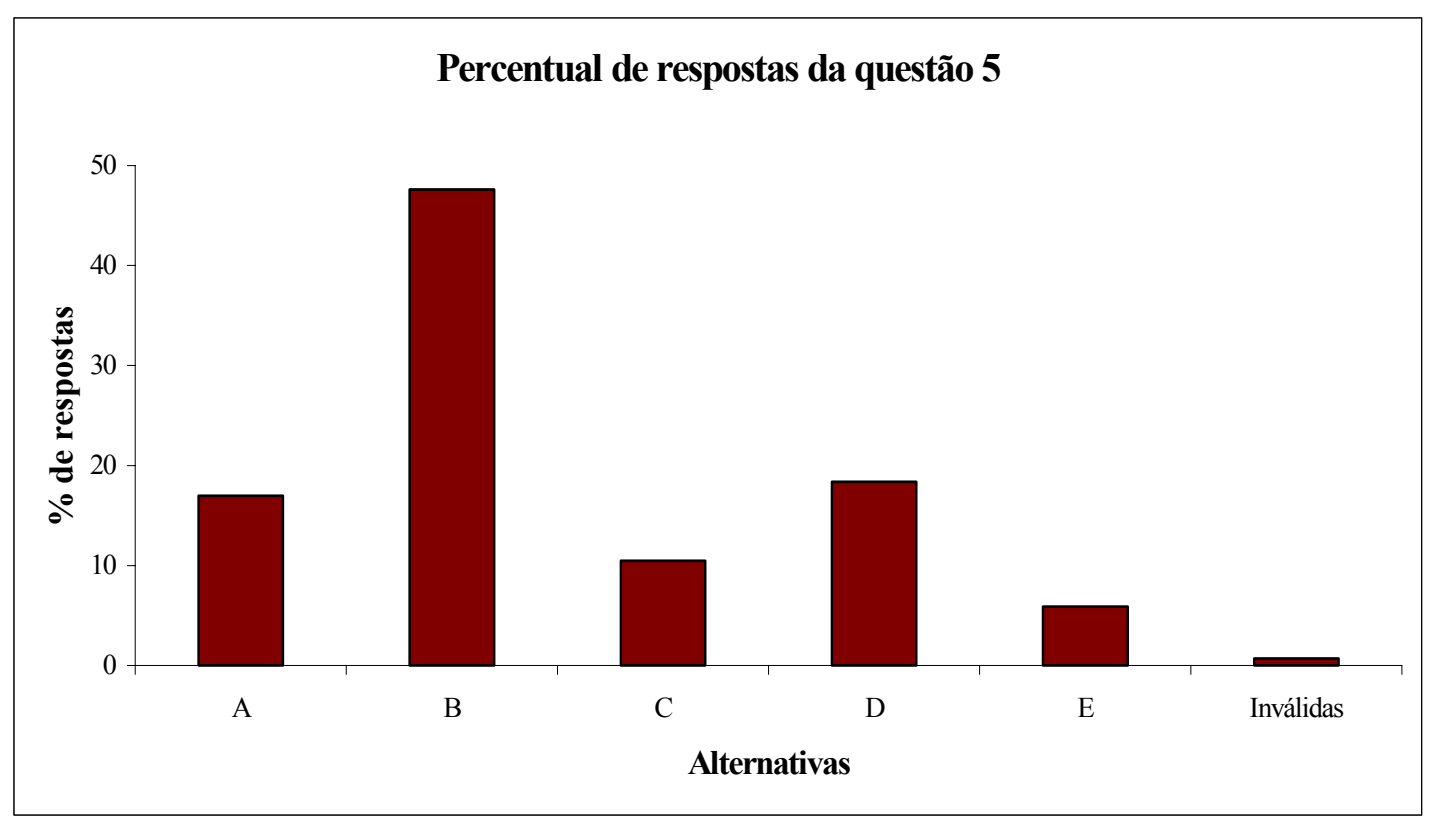

Gráfico 5 - Percentual de respostas da questão 5.

\section{1 - Análise Geral}

Trata-se de uma questão com excelente índice de discriminação $(0,68)$, tendo o grupo superior um índice de $85,93 \%$ de acerto, enquanto que o inferior concentra apenas $17,61 \%$; o índice de facilidade é considerado médio $(0,47)$.

Das respostas incorretas, a que obteve maior porcentagem de escolha foi a alternativa " $\mathrm{D}$ ", na qual $6,68 \%$ do grupo superior e $24,36 \%$ do grupo inferior a assinalaram, o que leva a supor que os estudantes desconhecem ou confundem as funções dos ribossomos e cromossomos.

Da mesma forma que na questão anterior, no livro texto o assunto é tratado de maneira descritiva sem que haja exemplos ou analogias.

Para obter êxito na resposta, é necessário que o estudante seja capaz de relacionar os conceitos aprendidos à analogia do texto.

A questão aborda os conceitos de citoplasma, núcleo, cromossomo, ribossomo e membrana nuclear. 
Para que o estudante responda corretamente, são necessários conhecimentos sobre a função de cada uma das estruturas citadas.

\section{2 - Abordagem no livro didático}

Segundo Campbell, 1998, "Dentro do núcleo, o DNA está organizado juntamente com proteinas no material chamado cromatina... Quando uma célula se prepara para dividir (reproduzir) um emaranhado fibroso de cromatina se condensa tornando-se grosso o bastante para ser percebido como estruturas separadas chamadas cromossomos.

Uma estrutura proeminente dentro de um núcleo que não está se dividindo é o nucléolo, onde os componentes dos ribossomos são sintetizados e reunidos. Estes componentes passam através dos poros da membrana nuclear para o citoplasma, onde se combinam para formar ribossomos...O núcleo controla a síntese de proteínas no citoplasma por enviar mensageiros moleculares na forma de RNA... este RNA mensageiro é sintetizado no núcleo de acordo com instruções vindas do DNA. O RNA $A_{m}$ carrega a mensagem genética para o citoplasma através dos poros da membrana nuclear. Uma vez no citoplasma, uma molécula de $R N A_{m}$ se une aos ribossomos, onde a mensagem genética é traduzida na estrutura primária de uma proteína especifica." 


\section{Questão 6 - Quadro VI}

6. Alguns bolos são servidos assim que saem do forno, enquanto outros recebem acabamento especial. $\mathrm{Na}$ analogia considerada, o local da confeitaria onde os bolos recebem recheio e cobertura, corresponde
(A) à mitocôndria.
(B) ao retículo endoplasmático rugoso.
(C) ao peroxissomo.
(D) ao lisossomo.
(E) ao complexo de Golgi .

Percentual de respostas da questão 6 nas três categorias consideradas

\begin{tabular}{lc|ccc|cc} 
& $\% \boldsymbol{A}$ & $\% \boldsymbol{B}$ & $\% \boldsymbol{C}$ & $\% \mathbf{D}$ & $\% \mathbf{E}$ & $\%$ Inv. \\
\hline Geral & 17,34 & 34,36 & 6,41 & 6,60 & $\mathbf{3 4 , 7 0}$ & 0,58 \\
Inferior & 28,06 & 23,87 & 8,52 & 10,47 & $\mathbf{2 7 , 5 7}$ & 1,51 \\
Superior & 3,37 & 46,08 & 3,81 & 1,92 & $\mathbf{4 4 , 6 1}$ & 0,21 \\
\hline
\end{tabular}

Tabela 9 - Percentual de respostas da questão 6 


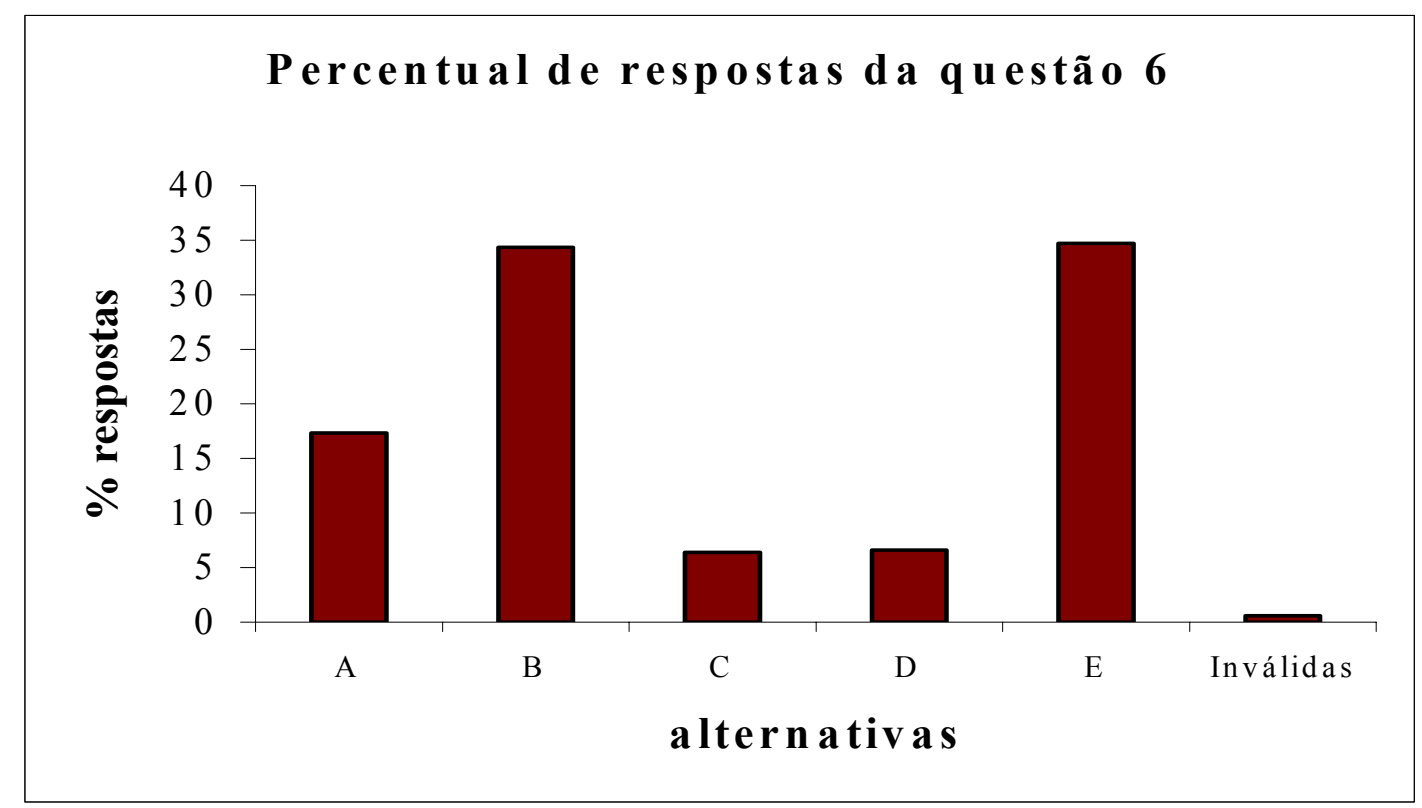

Gráfico 6 - Percentual de respostas da questão 6

\section{1 - Análise Geral}

Trata-se de uma questão com índice de discriminação fraco $(0,17)$, na qual $44,61 \%$ do grupo superior e $27,57 \%$ do grupo inferior a responderam corretamente; de acordo com o índice de facilidade, esta é uma questão difícil $(0,34)$.

Das respostas incorretas, a que obteve maior porcentagem de escolha foi a alternativa "B", na qual $46,08 \%$ do grupo superior e $23,87 \%$ do grupo inferior a assinalaram.

No livro didático, o assunto é tratado de maneira descritiva, não são explorados exemplos ou analogias.

Para obter êxito na resposta, é necessário que o estudante seja capaz de relacionar os conceitos aprendidos à analogia do texto.

Comparando-se a alternativa correta (E) com a que teve maior índice de escolha dentre as incorretas (B), pode-se constatar que a função do complexo de Golgi e retículo endoplasmático rugosos são pontos de dúvida dentre os estudantes; se forem analisadas apenas as respostas do grupo superior, verifica-se que 46,08\% 
dos estudantes assinalaram a alternativa "B", incorreta, e 44,61\% optaram pela "E", correta, havendo $1,47 \%$ de estudantes a mais optando pela alternativa errada.

Este fato é curioso e voltando-se ao livro didático, "Podemos pensar no complexo de Golgi como um centro de produção, armazenagem, classificação e distribuição. Aqui os produtos do retículo endoplasmático são modificados e armazenados e então enviados a outros destinos..." (Campbell, 1998), observa-se que, tendo o complexo de Golgi diversas funções, a de modificação das substâncias recebidas do retículo endoplasmático passa despercebida por parte dos estudantes.

A questão aborda os conceitos de mitocôndria, retículo endoplasmático rugoso, peroxissomo, lisossomo e complexo de Golgi.

Para que o estudante responda corretamente, são necessários conhecimentos sobre a função de cada uma das estruturas citadas. Supomos que essas funções foram simplesmente decoradas para a realização de avaliações, mas que o aprendizado verdadeiro não ocorreu e, portanto os estudantes apresentaram dificuldades em responder às questões devido ao uso de uma analogia. Só é capaz de responder uma questão através de analogias quando ocorre aprendizado significativo.

As questões 4, 5 e 6 abordam as estruturas e funções das organelas celulares por meio de analogias. Os estudantes apresentam muita dificuldade em relacionar conceitos às analogias, só é capaz de fazê-lo aquele que aprendeu significativamente e ainda tem-se uma parcela considerável de estudantes aprendendo por memorização, fato que torna esse tipo que questão difícil.

\subsection{Abordagem no livro didático}

Segundo Campbell, 1998, "Muitos tipos de células especializadas secretam proteínas produzidas pelos ribossomos unidos ao retículo endoplasmático rugosos...A maioria das proteínas secretadas são glicoproteínas...estas proteínas são produzidas e a membrana do retículo endoplasmático as mantém separadas das proteínas produzidas por ribossomos livres, que irão permanecer no citosol...Depois de deixar o retículo endoplasmático, muitas vesículas de transporte migram para o 
complexo de Golgi. Podemos pensar no complexo de Golgi como um centro de produção, armazenagem, classificação e distribuição. Aqui, os produtos do retículo endoplasmático são modificados e armazenados e então enviados a outros destinos... Um lisossomo é uma vesícula de enzimas hidrolíticas, rodeada por membrana, que a célula usa para digerir macromoléculas... Lisossomos funcionam na digestão intracelular em uma variedade de circunstâncias...Mitocôndrias são os locais da respiração celular, um processo catabólico que produz ATP pela extração de energia de açúcares, gorduras e outras fontes com a ajuda do oxigênio... $O$ peroxissomo é um compartimento metabólico especializado, limitado por uma membrana única. Peroxissomos contêm enzimas que transferem hidrogênio de vários substratos para oxigênio, produzindo peróxido de nitrogênio $\left(\mathrm{H}_{2} \mathrm{O}_{2}\right)$."

\section{Questão 7 - Quadro VII}

7. A clonagem animal vem sendo realizada desde a década de 50. Entretanto, em 1997, o experimento que levou ao nascimento da ovelha Dolly causou impacto científico e social por ser o primeiro a demonstrar que células

(A) germinativas de mamíferos, quando clonadas, podem originar indivíduos que chegam à fase adulta, porém são estéreis.

(B) germinativas de mamíferos, quando clonadas, podem originar novas células germinativas e novas células somáticas.

(C) somáticas diferenciadas, obtidas de mamíferos adultos, podem originar indivíduos viáveis.

(D) somáticas diferenciadas sofrem modificações do material genético que não podem ser revertidas.

(E) somáticas indiferenciadas, obtidas de fase embrionária são incapazes de gerar indivíduos viáveis. 
Percentual de respostas da questão 7 nas três categorias consideradas.

\begin{tabular}{lc|ccc|cc} 
& \% $\mathbf{A}$ & $\mathbf{\%} \mathbf{B}$ & $\mathbf{\%} \mathbf{C}$ & $\mathbf{\%} \mathbf{D}$ & $\mathbf{\%} \mathbf{E}$ & $\mathbf{\%}$ Inv. \\
\hline Geral & 9,95 & 24,59 & $\mathbf{5 5 , 9 6}$ & 5,25 & 3,73 & 0,53 \\
Inferior & 16,75 & 37,44 & $\mathbf{2 8 , 7 4}$ & 9,85 & 5,76 & 1,46 \\
Superior & 2,57 & 9,34 & $\mathbf{8 5 , 1 0}$ & 1,12 & 1,83 & 0,03 \\
\hline
\end{tabular}

Tabela 10 - Percentual de respostas da questão 7

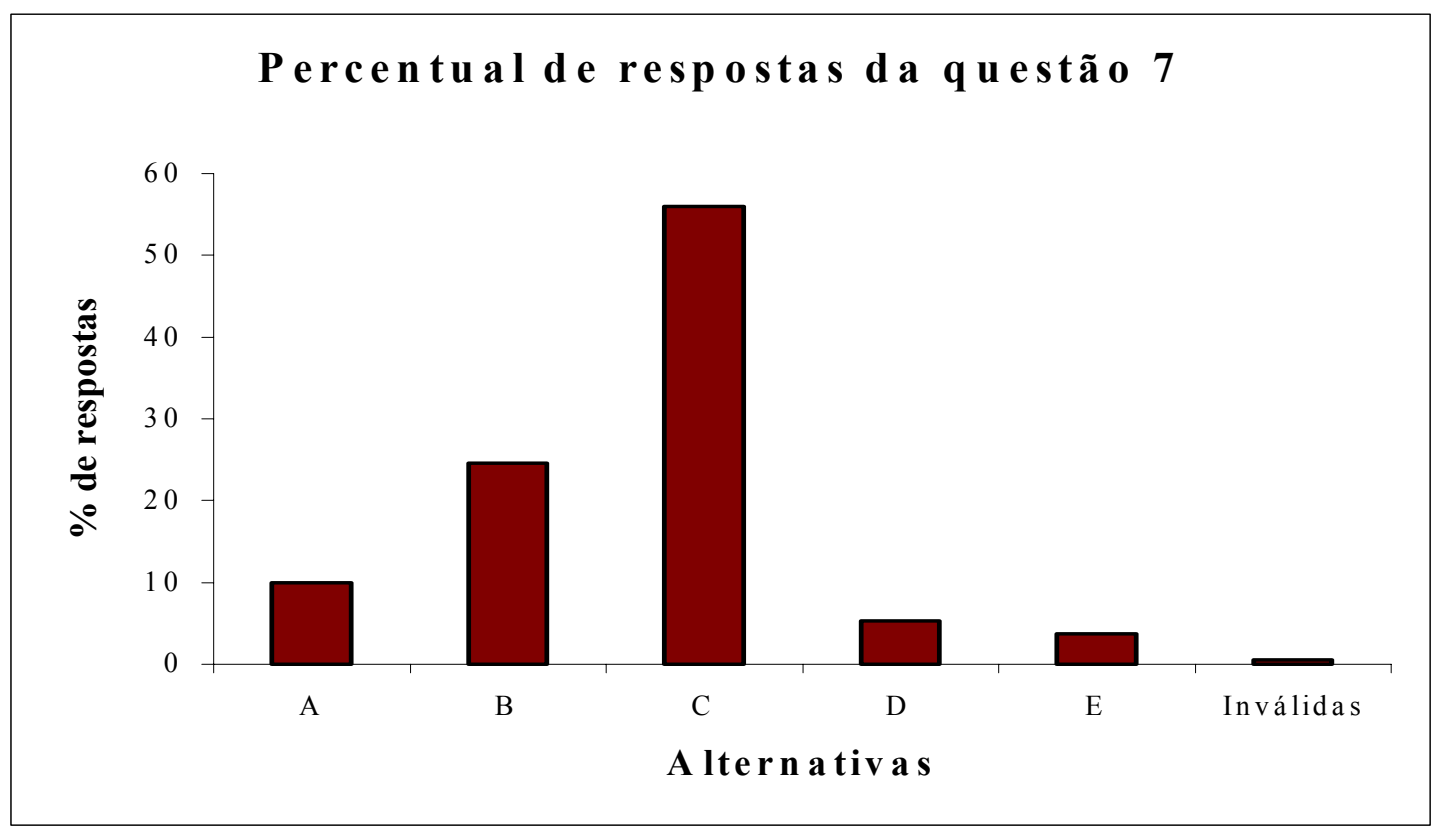

Gráfico 7 - Percentual de respostas da questão 7 


\subsection{Análise Geral}

Esta é uma questão com excelente índice de discriminação $(0,56)$, pois $85,10 \%$ dos estudantes do grupo superior e $28,74 \%$ do inferior assinalaram a alternativa correta (C); quanto ao índice de facilidade é considerada uma questão de índice médio $(0,55)$.

A alternativa incorreta mais assinalada foi a "B", na qual 9,34\% do grupo superior e $37,44 \%$ do inferior a assinalaram. Do grupo inferior houve um número maior de estudantes $(37,44 \%)$ optando pela alternativa incorreta do que pela correta $(28,74 \%)$.

Analisando-se os livros didáticos, observa-se que o assunto não é abordado de maneira clara e específica, não há explicações detalhadas sobre o assunto.No entanto, o assunto foi exaustivamente abordado por outras fontes, tais como livros paradidáticos, jornais, revistas, enfim pela mídia e literatura em geral, o que leva a supor que os estudantes não têm o hábito de leitura além do conteúdo da aula que será cobrado nas avaliações.

O principal conceito abordado na questão é a técnica de clonagem utilizada na ovelha Dolly.Para que os estudantes respondam a esta questão, além de conhecer a técnica utilizada para a clonagem da ovelha Dolly, também precisam conhecer conceitos de células somáticas e germinativas.

\subsection{Abordagem no livro didático}

Foi encontrado em Griffthis, 2001, um pequeno quadro que dá o seguinte enfoque: "Em fevereiro de 1997, as primeiras páginas dos principais jornais mundiais apresentaram a figura de uma bonita ovelha chamada Dolly, que foi produzida pela implantação do núcleo de uma célula do úbere de uma ovelha Finn Dorset no ovócito enucleado de uma ovelha Scottish Black Face. Este processo, que parece simples, seria bem-sucedido somente se as células doadoras estivessem" famintas "em cultura, de modo a induzir a parada da divisão celular mitótica, em uma 
manobra que parecia tornar o núcleo doador compativel com o ovócito receptor, o que ocorreu em um estágio posterior da meiose. Este resultado experimental surpreendente demonstrou que o núcleo de um mamífero ainda é "totipotente". ",

\section{Questão 8 - Quadro VIII}

8. As mitocôndrias possuem uma única molécula de DNA circular. Isto torna a organização do material genético dessas organelas semelhante à organização do material genético presente em
(A) bactérias e cloroplastos.
(B) plantas e algas verdes.
(C) fungos e vírus.
(D) vírus e bactérias.
(E) protozoários e cloroplastos.

Percentual de respostas da questão 8 nas três categorias consideradas

\begin{tabular}{lc|ccc|cc} 
& $\% \boldsymbol{A}$ & $\% \boldsymbol{B}$ & $\% \boldsymbol{C}$ & $\% \boldsymbol{D}$ & $\% \boldsymbol{E}$ & $\%$ Inv. \\
\hline Geral & $\mathbf{3 5 , 9 1}$ & 8,26 & 4,93 & 41,98 & 8,44 & 0,48 \\
Inferior & $\mathbf{1 5 , 5 0}$ & 15,84 & 8,42 & 44,53 & 14,46 & 1,25 \\
Superior & $\mathbf{6 8 , 4 6}$ & 1,15 & 0,98 & 26,87 & 2,51 & 0,03 \\
\hline
\end{tabular}

Tabela 11 - Percentual de respostas da questão 8 


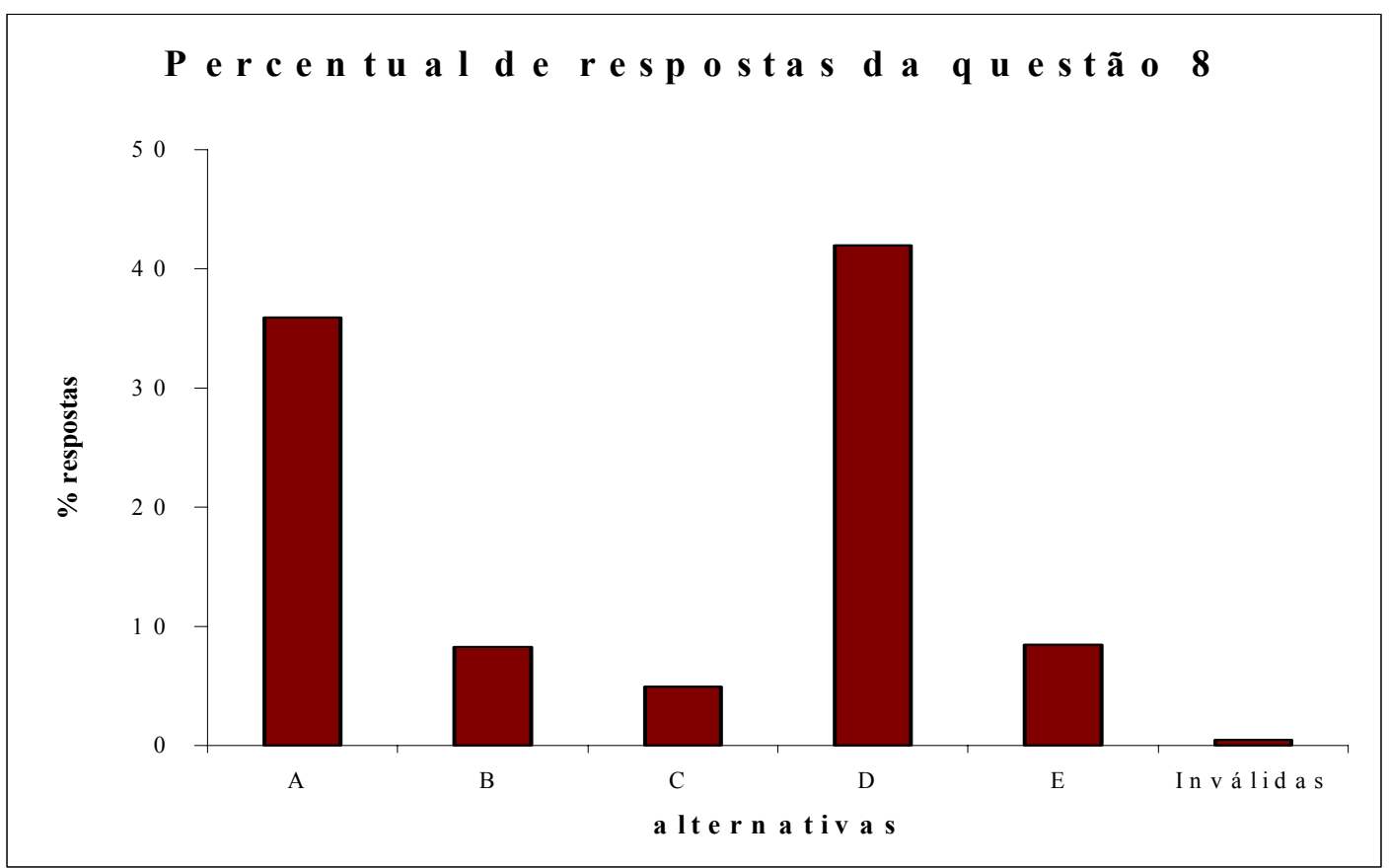

Gráfico 8 - Percentual de respostas da questão 8

\section{1 - Análise Geral}

Trata-se de uma questão com índice de discriminação excelente $(0,53)$, tendo o grupo superior um índice de $68,46 \%$ de acerto, enquanto que o inferior concentra apenas 15,50\%. Considerando-se o índice de facilidade, esta é uma questão considerada difícil $(0,35)$.

Das respostas incorretas, a que obteve maior porcentagem de escolha foi a alternativa "D", na qual $26,87 \%$ do grupo superior e $44,53 \%$ do grupo inferior a assinalaram.

No livro didático, o assunto é tratado de maneira descritiva e não são feitas abordagens sob o aspecto comparativo.

Para responder corretamente a questão, o estudante deve ser capaz de relacionar e diferenciar os diversos tipos de DNA dos vários organismos e organóides citados; trata-se, portanto, de uma questão de conhecimento. 
Comparando-se a alternativa correta (A) com a que teve maior índice de escolha dentre as incorretas (D), pode-se constatar que o DNA de bactérias, cloroplastos, vírus e mitocondrial, são pontos de dúvida dentre os estudantes, pois $44,53 \%$ dos estudantes do grupo inferior e $26,87 \%$ do superior atribuíram a vírus e bactérias a característica de DNA circular. Ao investigar a abordagem feita por Campbell, 1998, encontra-se a possível origem deste problema, isto é, tanto vírus quanto bactérias podem apresentar um DNA circular; a questão apresenta duas alternativas possíveis de serem corretas, o que permite afirmar que trata-se que uma questão que apresenta falhas na elaboração.

A questão aborda os conceitos de DNA mitocondrial, bacteriano, viral, de protozoários, de cloroplastos, de plantas e algas verdes e de fungos.

Para que o estudante responda corretamente, são necessários conhecimentos sobre a forma e o funcionamento de cada um dos diferentes tipos de DNA.

\section{2 - Abordagem no livro didático}

Segundo Campbell, 1998, “A maior parte do genoma eucariótico está contida dentro dos cromossomos, no núcleo. Contudo, além do DNA nuclear, algumas organelas celulares - cloroplastos e mitocôndrias - também contêm um tipo cromossômico específico da organela. Os cromossomos mitocondriais e de cloroplastos consistem em moléculas de DNA bifilamentares. As mitocôndrias e os cloroplastos individuais contêm múltiplas cópias idênticas de seus cromossomos, e cada célula contém inúmeras dessas organelas...A análise dos genomas organelares demonstra que eles são inerentemente circulares; contudo podem se detectar formas lineares desses genomas nas células. Muitos genes organelares possuem íntrons... Os vírus são compostos de um revestimento protéico e de um centro que contém seu genoma. Durante a infecção, o genoma viral entra na célula, mediado tanto pela fusão do revestimento viral com a membrana plasmática da célula, quanto por um processo de injeção semelhante a uma seringa... Os genomas virais são bastante variados. Os genomas de muitos vírus são compostos de DNA. Quando comparados na partícula viral, em alguns vírus, o DNA é bifilamentar, em outros casos, unifilamentar. Ainda há outros vírus, como o retrovírus, que possuem genomas de 
RNA na partícula viral. Alguns genomas virais contêm moléculas lineares de DNA ou RNA, ao passo que outros são circulares. Portanto observamos uma diversidade muito grande nos tipos de moléculas que formam os genomas virais em comparação com os genomas de DNA bifilamentares encontrados em todas as células vivas...A maioria dos genomas virais não possui introns.

O genoma da maioria dos procariotas está contido dentro de um único cromossomo. Para a maioria dos procariontes, este cromossomo é uma dupla-hélice de DNA única, fechada e circular... Os genes bacterianos estão organizados juntos uns aos outros, com pouco espaço intergênico e os intros são extremamente raros...Acredita-se que os genomas bacterianos possuam proteínas associadas que ajudam a compactar o genoma em um nucleóide.

Em organismos eucarióticos a grande maioria dos genes é encontrada nos cromossomos do núcleo. A maioria das espécies eucarióticas é classificada como diplóide...ou haplóide...A maioria dos fungos e algas é haplóide, ao passo que a maioria dos outros eucariontes é diplóide...Cromossomos diferentes no genoma contêm diferentes grupos de genes...cromossomos diferentes possuem grupos distintamente diferentes de genes." 


\section{Análise das Entrevistas - Parte A}

No início das entrevistas a pesquisadora ressaltou aos entrevistados que não deveria haver preocupação com respostas decoradas e definições prontas; o que se esperava com as questões é que os graduandos respondessem com suas próprias palavras aquilo que tinha ficado em sua mente de cada um dos tópicos questionados.

Cada entrevista durou em média quinze minutos e transcorreu no sentido de uma conversa informal. Os questionamentos foram feitos abordando os mesmos conceitos envolvidos em cada uma das oito questões do ENC-BIO/2002, cujos resultados foram previamente analisados (Parte A), sendo que as duas últimas questões trataram da metodologia utilizada nas aulas do curso de graduação (Parte B).

A seguir, apresentaremos trechos das entrevistas com o objetivo de complementar os resultados analisados dos questionários e de ilustrar os conhecimentos que os graduandos apresentaram sobre determinados conceitos da Genética. Os trechos apresentados nos resultados foram transcritos exatamente da maneira como o estudante falou. Dessa maneira, será comum encontrar problemas com a concordância e erros de linguagem.

As questões aplicadas nas entrevistas serão aqui apresentadas por assunto ou por conceitos que se relacionam e não seguem, necessariamente, a mesma seqüência em que foram feitas aos graduandos nas entrevistas. Optamos por apresentar os resultados agrupando questões de acordo com conceitos relacionados para facilitar a leitura e a discussão. Em todas as questões há um comentário da pesquisadora seguido de trechos das entrevistas.

Os comentários que constam ao longo da análise foram pautados nos seguintes critérios:

a) O estudante declara desconhecimento do assunto.

b) São apresentadas explicações para o conceito questionado, porém essas explicações são confusas, ou superficiais, ou distorcidas, ou ainda fazem parte do senso comum. São freqüentes as respostas com palavras soltas e desconexas. 
c) As respostas apresentadas possuem embasamento teórico. O estudante apresenta respostas completas e pautadas em conhecimentos científicos.

d) Além das explicações cientificamente corretas os estudantes são capazes de estabelecer relações adequadas entre os diversos conceitos biológicos.

Utilizamos a letra "G" na identificação dos estudantes entrevistados por ser a inicial de "Graduando", já que todos os entrevistados eram estudantes de último ano.

Cabe ressaltar que realizamos uma pesquisa qualitativa, no entanto, nos casos em que encontramos um número muito elevado ou muito reduzido de estudantes com respostas adequadas ou inadequadas para um mesmo conceito, decidimos utilizar valores percentuais para que o leitor possa ter a real dimensão do resultado obtido.

Um fato bastante marcante que podemos notar é que, muitas vezes, estudantes oriundos de uma mesma Instituição de Ensino e de uma mesma turma e que, portanto, participam de uma mesma situação de ensino-aprendizagem, apresentam concepções diferentes sobre determinado tópico ou ainda, enquanto um apresenta uma conceituação dentro do considerado cientificamente correto outro, simplesmente, declara desconhecer o assunto ou apresenta uma definição do senso comum.

\section{II.1 - O Conceito de Mutação}

Ao perguntarmos aos estudantes o que ele lembram quando ouvem a palavra mutação e quais as conseqüências para o organismo desse processo, percebemos que é muito forte entre os graduandos o conceito de que a mutação é um acontecimento prejudicial ao organismo. Alguns graduandos conseguem relacionar mutações com estruturas celulares, enquanto outros nem chegam a citar.

G01 - “Alguma coisa prejudicial.”

G07 - "Uma alteração que pode prejudicar o ser humano."

G11 - “Genes, mitose, meiose, Genética, problemas genéticos, problemas na separação das cromátides. Trazem conseqüencias ao organismo como 
doenças genéticas e algumas síndromes."

G13 - "Código genético, cromossomos, uma alteração nos genes ou nos cromossomos, pode ser estrutural, pode ser no número de cromossomos, pode ser no gene. As conseqüências é que pode trazer doenças, mal formação do corpo, doenças genéticas."

G24- "Lembro de aberração, mesmo sabendo que não é isso, que não chega a ser uma coisa ruim. Quando eu lembro da palavra mutação me vem na cabeça aberração. A conseqüencia depende, às vezes ela pode ser boa, pode trazer ao organismo uma adaptabilidade maior a um determinado ambiente, ou não, ela pode ser maléfica para esse indivíduo, dependendo do ambiente onde ele está inserido. Ela acontece nos genes, na verdade acho que ela acontece em todo o DNA, mas a gente só percebe, as que a gente pode estudar é nos genes."

G27- "Acontece por diversos fatores, radiação UV, acontece no DNA, acontece alguma mudança na estrutura da molécula de DNA, nas bases nitrogenadas, elas podem mudar, sofrer uma mudança química na estrutura da molécula que leva a formar uma molécula tal que houve uma mudança química e ela passa a ser diferente do que ela era e isso passa a acarretar doenças, pode acarretar doenças genéticas."

G29- "Falhas no código genético, causa doenças."

É possível perceber que outros graduandos apresentam concepções diferentes sobre mutação e destacam que a mutação pode ser tanto benéfica quanto prejudicial. Alguns conseguem definir mutações, citando, por exemplo, alteração de bases nitrogenadas. Outros, porém, encontram dificuldades em definir o conceito, mas, mesmo assim, percebem que a mutação pode trazer benefícios.

G14 - “Genes, o material genético se modificando. Pode ser ruim trazendo doenças, aberrações cromossômicas ou pode ser boa. Pode trazer benefícios." 
G15 - “Mudanças, alterações. Se eram metacêntricos passam a ser submetacêntricos e vice-versa. Alguma coisa mudou. Elas podem tanto ajudar quanto prejudicar. Se elas forem prejudicial o organismo morre. Se elas forem ajudar, continua a sobreviver."

G17 - "Citogenética. Uma coisa que acontece e que pode trazer beneficios ou maleficios. Acontece um erro numa mitose, incorpora algumas bases ou perde algumas. Como conseqüências pode ser maleficios ou pode continuar na mesma, pode não ser nem bom e nem ruim, de repente é em um códon que não tem importância, então ninguém vai perceber, mas se é uma proteína super importante para algum fato, ele vai ter uma perda da proteina e adquirir a doença."

G18-“ Alguma alteração no DNA, anormalidades no DNA... Não anormalidades, mas uma mudança. Se ela é boa ou ruim, depende. NA verdade você acaba descobrindo o efeito que ela vai ter mais pra frente. Quando você pára para analisar ela pode causar alguma doença, normalmente é uma coisa maléfica."

G20- "Mudança nos genes, ou em um gene ou em mais de um gene, alteração pontual ou não. As conseqüências podem ser positivas e podem ser negativas. A gente associa mais a mutação a uma negativa, mas pode ter uma conseqüência positiva, então de tornar o ser, tornar um organismo mais apto para viver em determinadas condições; pode ter uma conseqüência negativa também, pode causar doenças. Não só tem a conseqüência positiva como também tem a negativa da mutação."

G21- "Alteração de bases nitrogenadas e do genoma. Pode ter conseqüências benéficas ou maléficas, depende da mutação, da região e da troca."

G32- "Mudança, alteração no DNA. As conseqüências são desde não ter alteração nenhuma, se não for nenhuma região de início, pode ter uma alteração 
deletéria e também pode ser uma coisa benéfica. Melhorar, de repente uma proteina melhor que vai dar alguma vantagem para aquele organismo naquele ambiente."

Como citado anteriormente, alguns graduandos apresentam uma concepção ingênua e superficial de mutação. No entanto outros estabelecem relações cientificamente válidas entre mutação, evolução e especiação.

G10 - "Mutação é uma alteração de..., da base primária,... da base não, do original,... e a mutação nem sempre é maléfica, na verdade é ela que proporciona o avanço também, foi através de mutações que aconteceram mudanças que chegou no que a gente é hoje e os outros animais também, mutação também está envolvida com evolução."

G12 - "DNA, pares de bases mutaram por algum motivo e não se pareiam corretamente, pode gerar alguma doença ou especialização. Como conseqüencias destaco a anemia falciforme, por exemplo. Tem a cadeia de DNA uma das bases mutou e esse par de bases está codificando um códon diferente, codifica um aminoácido diferente, então a proteína será diferente e aí nasce com a anemia falciforme. Então isso é uma coisa ruim. Mas ao longo da evolução as mutações foram boas porque teve a adaptação, teve mutação e com a pressão seletiva teve a diversidade; quem tinha mutado pode ter sido o mais apto e sobreviveu. Nem sempre ela é ruim."

G16 - "Evolução, mutação é uma coisa que pode dar errada ou dar certo e no final das contas a gente vai saber para que ela serve. No caso de uma evolução muitas vezes uma mutação serve para a espécie se adaptar ao novo ambiente e ela ocorre ao acaso, porque são vários indivíduos então uma hora vai sair algum que não vai sair igual a cópia anterior. Na verdade não, nem é cópia, cada um é de um jeito, então vai ter um que vai ter uma pequena diferença. A mutação ocorre nos genes." 
G19- "Mutação genética pode ser numérica ou estrutural. O cromossomo é alterado e essa mutação, essa alteração pode gerar ou não características mutantes. Ela pode gerar uma mutação que não seja expressa no indivíduo, que você não possa perceber pelo fenótipo, mas se você for analisar o cariótipo você percebe ela. Se é benéfica ou prejudicial, depende, se você for pensar na mutação que gera síndromes ou uma mutação que leva ao câncer pelos raios ultravioletas, a gente considera que a mutação levou para pior e não vai deixar o organismo ter as funções corretas. Se você for pensar em mutação ao longo da evolução, teoricamente não são mutações, são adaptações que vão ocorrendo para melhor."

G22- "Transformação. Mudança, transformação qualquer em qualquer tipo de organismo. Quando penso em mutação, penso em dois sentidos, porque eu não consigo separá-los. Eu sei que tem separação, mas eu não consigo separá-las. Tanto a nível gênico, no genoma do organismo quanto no fenótipo. Tanto no genótipo quanto no fenótipo. Então eu penso mutação em nível dos genes do organismo que muitas vezes não estão expressos no fenótipo, mas estão nos genes do organismo ou uma mutação mesmo no ambiente, no fenótipo do organismo. Conseqüências podem ser tanto positivas quanto negativas. Ou a extinção do organismo, aquela mutação foi drástica de forma que ele não está adequado àquele ambiente ou de forma positiva em que aquela mutação causou uma melhoram para o organismo viver naquele ambiente em que ele estava."

G23- "Mutação genética, no gene, fenótipo correspondente àquela mutação, DNA, DNA polimerase, enzimas reparadoras de DNA. As conseqüencias, dependendo do meio em que o indivíduo está inserido pode levar a uma conseqüência boa ou a uma conseqüencia ruim. Ele pode ser selecionado pelo meio ou não. Ele pode levar vantagem sobre os outros indivíduos da mesma espécie e se sair melhor." 
G25- "Mutação genética, troca de par de bases, não lembro direito o nome, mas tem alguma coisa do tipo translocação. A mutação é importante para a variabilidade dos fenótipos... espera aí, deixa eu pensar. Principalmente para adaptação, né. Para a seleção natural depois. A mutação é importante para criar a variabilidade dentro da espécie ou para a especiação mesmo, depois de várias mutações surgirem novas espécies."

G26- "Troca de algum pedaço de material genético. Pode ter desde mutações que não fazem nada. Tem mutações que podem causar síndromes e boas, o acúmulo de mutações podem ser importantes para o surgimento de alguma estrutura em termos evolutivos."

G28- "Na verdade como é ensinado pra gente é que a mutação é uma mudança pontual ou não do código genético e impreterivelmente me vem à cabeça, né, porque as mutações são mais facilmente identificadas visualmente quando é do caráter recessivo, principalmente com drosófila, cor de olho, white, caracteres anômalos que aparecem pelo fato de o gene se expressar em uma condição recessiva. A mutação pode ser tanto deletéria, quando ela afeta características de importância grande para o indivíduo sobreviver naquele momento, mas ela também é a fonte da variabilidade das espécies."

G30- "Lembro de seleção natural, de mudança de bases, da fita de DNA, ou exclusão de umas partes de um gene, modificações de um gene. Pode estar trazendo diferenças do estado mais abundante existente."

G31- "Algo que diferencia de algum jeito, ou para o bem ou para o mal. Ela ocorre nos genes, mas elas acabam sendo apresentadas no fenótipo mesmo. As conseqüencias podem ser de nenhuma a alguma coisa que pode ser deletéria ou algum caractere novo que possa ajudar na diferenciação da espécie."

G33 - “ A primeira coisa que me vem na cabeça é aquele esquema clássico do Ensino Médio, que é saber aquele monte de deleção, não sei o que, que a 
gente vê aqui na faculdade também, mas do processo em si eu lembro muito pouco. Eu lembro de algumas coisas, eu lembro que eu estudei quando eu vi duplicação de DNA, que eram os erros que eram reparados ou não, esse tipo de coisa. Pode trazer uma conseqüência positiva, você ter um valor adaptativo associado a essa mutação ou não ela pode trazer uma conseqüência negativa, dentro de seleção natural ou nada também, ou neutra também, pode ser que não aconteça nada."

\section{II.2 - O conceito de Variabilidade Genética}

Quando perguntamos aos estudantes o que eles lembram ao ouvir "variabilidade genética", há estudantes que tentam de alguma maneira responder, mesmo que sejam palavras soltas e sem sentido; outros, no entanto, nem sequer tentam, e alegam desconhecimento do assunto.

G14 - "Lembro da palavra, mas não lembro do significado. Não me vem nada no momento."

G18 - "Sinceramente eu não tenho um conceito disso. Mas eu acho que é pelo fato da diversidade, de como esse DNA vai reagir, quais são as... a expressão que ele vai ter. Os fatores que podem ocasionar acho que a influência do meio vai interferir nessa variabilidade do DNA. É importante porque a espécie continua, senão já teria sido exterminada."

G25 - “Por exemplo, dentro de uma espécie com variabilidade genética, isso significa que ... é dificil, não sei te explicar."

Para o Estudante G11 a variabilidade genética leva à mutação.

G11 - "Cruzamentos genéticos, entre as espécies diferentes levam a uma variabilidade genética, leva a uma mutação do DNA. Ela é ocasionada pelos cruzamentos, pode ser pequena ou grande, depende do genótipo talvez." 
Durante a entrevista com este estudante, percebemos que apesar de ele conhecer os termos, desconhece o conceito. A resposta é formulada com palavras soltas, desconexas e sem sentido. Outros estudantes também respondem de maneira confusa, tentando explicar o conceito por meio do uso de termos científicos, porém não há sentido nas respostas ou há uma confusão generalizada nas idéias.

G13- "A seqüência de DNA diferente. Para mim variabilidade genética é isso, uma seqüência diferente de DNA, a seqüencia de bases do DNA. Através da variabilidade genética é que se pode expressar cor, é bom ter variabilidade genética senão seria tudo igual, né. Ela se origina pela meiose, crossingover."

G32 - "É importante para a população, porque se for todo todo mundo homogêneo, se acontecer alguma coisa, alguma alteração no ambiente, alguma doença pode vir a atacar todos os organismos, então é importante. Os fatores que contribuem para a ocorrência da variabilidade são principalmente os intrínsecos, né, do próprio erro nas duplicações, nas transcrições ou externos, né. Os fatores externos podem alterar o DNA, no caso da mutação vai estar alterando o DNA e vai estar causando uma debilidade."

O estudante G10 explica o conceito de variabilidade genética de maneira simplista e por meio do senso comum.

G10 - "É através da variabilidade genética que a gente consegue coisas novas. É extremamente importante e é ocasionada pela mistura de material genético de organismos diferentes... Diferentes acho que não, mas de um macho e uma fêmea de determinada espécie que trocam seus gametas e isso proporciona a variabilidade genética. É ótimo porque você melhora e espécie através disso." 
Durante as entrevistas pudemos constatar que há graduandos que são capazes de relacionar variabilidade genética a outros conceitos, como mutação, adaptação, seleção natural, evolução e especiação.

G12 - "Pode ser de vários tipos. Pode ser a variabilidade dentro da espécie e a variabilidade entre as espécies. A variabilidade ocorreu também, ... além da pressão seletiva, da seleção natural, são mutações também. É muito bom a variabilidade dentro de uma espécie e a reprodução sexuada também que traz a variabilidade, porque numa pressão seletiva nem todos os indivíduos morrem, a espécie consegue continuar. A reprodução sexuada também contribui para a variabilidade e entre as espécies também, porque a biodiversidade é rica também. Imagina as plantas. Tem vários tipos de plantas com vários metabólitos secundários, por exemplo, que serve como plantas medicinais. Então com essa variabilidade existe vários tipos de produtos que podem ser retirados de cada planta."

G17 - "Lembro de cruzamento sexuado. É importante para o desenvolvimento das espécies, da evolução mesmo, para não ficar exatamente igual aos pais. $O$ crossing-over é um dos fatores que leva a variabilidade."

G21 - “É o substrato da seleção natural. Alelos também. É aleatório; o surgimento de uma nova variabilidade é aleatório. Agora, se ela permanecerá ou não em uma população é a seleção natural que irá decidir. Parece que quanto maior a variabilidade dentro de uma população maior a probabilidade de sobrevivência dessa população frente a mudanças ambientais."

G23 - “Lembro de polimorfismos, várias coisas, né. Variabilidade genética de uma população, a variabilidade genética pode vir a originar uma espécie nova. Os fatores que contribuem para a variabilidade são as mutações, o meio, fenômenos naturais que acontecem. Ela é essencial, se não tivesse a variabilidade genética muitas espécies já teriam sido extintas, todo mundo 
iria ser igual, iria acontecer coisas que selecionam alguns, as doenças, por exemplo."

G24 - "Eu lembro de diversidade, de vírus, diversidade de fenótipos. Os fatores que contribuem são os cruzamentos entre indivíduos não parentais e mutações. É importante porque se variar o ambiente, o clima se os indivíduos tiver variabilidade pode existir uma plasticidade para se adaptar a uma mudança de clima, do ambiente, por exemplo."

G28 - "Há exemplo de plantas onde a variabilidade genética.é muito grande dentro das espécies, então você vê em uma mesma espécie plantas muito diferentes, tem umas plantas muito grandes outras muito pequenas com formato da flor diferenciado. Variabilidade são vários caracteres tanto a nível molecular quanto a nível fenotípico que diferenciam os indivíduos dentro de uma mesma espécie ou de um mesmo gênero. É muito importante para o processo da evolução, porque a partir do momento que você muda as condições ambientais, você tem uma mudança da seleção natural sobre uma devida população de indivíduos, a variabilidade permite que alguns indivíduos respondam bem a essa mudança do ambiente e aí você mantém a espécie."

G33 - "Primeira coisa que eu lembro é seleção natural mesmo, aquela velha historinha de que variabilidade genética para que você possa ter seleção natural, tem que ter coisas diferentes para que você possa selecionar, e está relacionado a mutação, se as falhas vão ser reparadas ou não, quero dizer falhas no processo de duplicação do DNA, e aí como é que isso vai ser visto numa população e se isso vai alterar ou não a dinâmica da população, da comunidade. É importante porque se você selecionar uma mutação que tenha valor adaptativo você vai poder aumentar o fitness dos individuos e você vai poder ter uma população que vai poder ter uma competição melhor, sei lá, vai competir melhor, os indivíduos vão ganhar na competição com outros individuos." 
A resposta do estudante $\mathrm{G} 27$ chamou-nos a atenção pelo fato de percebermos que o entrevistado tinha conhecimento do assunto, mas encontrava dificuldades em articular as palavras, não encontrava os termos corretos para poder explicar suas idéias.

G27 - "As informações genéticas que estão no DNA, elas são dentro de uma espécie, elas são mais ou menos ... não iguais, né. Aí que está a variabilidade, tem a mesma informação só que nem sempre é a mesma. Dentro da espécie há variações de indivíduo para indivíduo, as variações são devido a essa variabilidade genética que estão dentro do DNA, né. Porque o DNA são aquelas seqüências de bases nitrogenadas, aquelas seqüências de letras que seriam iguais para a mesma espécie só que há a variabilidade que dá a individualidade de cada um, de cada indivíduo dentro de uma mesma espécie. É importante por causa da evolução, né. Só através dessa variabilidade genética é que há evolução, as mutações é que dão essa variabilidade genética para a espécie e só através dessa variabilidade genética e das mutações é que ocorre a evolução da espécie. Para o indivíduo eu não sei se tem alguma vantagem. Deve ter né. Deve ser para ele se adaptar melhor ao ambiente em que ele vai deixar seus descendentes $e$ esse é o significado da vida, né, passar seu genótipo a frente."

Os estudantes G16 e G19 respondem à questão de maneira simples e completa, usando as próprias palavras, evidenciado um aprendizado significativo.

G16 - "Eu lembro de quase a mesma coisa que mutação. Vai ter diferentes possibilidades numa mesma, ... numa troca. Por exemplo, numa fecundação vai ter cromossomos do pai, da mãe e o descendente vai ser diferente. Se fosse sempre o mesmo, um clone, uma partenogênese, não iria ter variabilidade. Então variabilidade genética são as modificações, o que pode se encontrar como resultado dessa mistura. Os fatores que levam a essa variabilidade são a reprodução sexuada, troca de material genético, acontece em plantas, em seres que tem reprodução sexuada. É importante 
para não ser sempre o mesmo gene, se mudar o ambiente ele vai estar mais propenso a se extinguir, porque ele não tem como se adaptar. Não houve uma mutação para ele estar preparado, ao acaso mesmo no novo ambiente."

G19 - "Adaptação. Eu sempre vejo a nossa variabilidade genética, de todo mundo não ser igual, tem o mesmo genoma, mas tem as diferentes seqüências, que é isso que diferencia e explica porque tem pessoas diferentes. Evolutivamente quando você analisa um todo você consegue ver que a variabilidade gera diversas coisas. Ela pode ser ocasionada por fatores externos, fatores do meio ambiente, os seres têm que se adaptar mesmo, tanto com a gente, como com plantas ou com animais. Para a sobrevivência mesmo. Eles se adaptam para sobreviver."

\section{II.3 - Conceito de Genótipo fundador}

Quando perguntamos aos estudantes do que eles se lembram quando ouvem o termo efeito do fundador ou genótipo fundador, a grande maioria, ou seja,vinte e quatro dos trinta e três entrevistados, o que corresponde a 72,72\%, afirmam que nunca ouviram falar ou simplesmente que não sabem.

G01- "Nunca ouvi falar! O que é isso?"

G02 - "Eu não sei o que é."

G08 - "Nunca ouvi falar. Não tenho idéia."

G11 - "Nunca ouvi falar disso. Talvez tenha a ver com cruzamentos."

G12 - "Nunca ouvi falar, só genótipo sim, mas genótipo fundador não."

G13 - "Não, nunca ouvi." 
G14 - “Não sei, Nunca ouvi falar.”

Alguns estudantes, no entanto, parecem sentir-se constrangidos em afirmar desconhecimento do assunto e tentam, de alguma maneira, explicar, mesmo que de maneira inadequada. Tentam responder estabelecendo relação entre os significados das palavras "efeito" e "fundador", isoladamente. Por se tratar de uma questão extremamente interessante abordaremos este assunto mais detalhadamente na discussão

G03 - "Acho que são aqueles genes que você tem, que vem do seu pai, da região. É isso?"

G05 - "Imagino que nessa história do genótipo fundador teria um gene dominante, em cada população. Mas eu nunca ouvi falar de genótipo fundador.”

G06 - "Genótipo fundador tem que ser uma pessoa com o gene recessivo e a outra pessoa também com gene recessivo. Na verdade eu nunca ouvi falar este termo "genótipo fundador", eu nem sei o que é!"

G09 - "Fluxo gênico, envolvendo genética de populações. A gente teve isso bem fraco. Na verdade não tenho a menor idéia do que seja genótipo fundador."

G15 - "Acho que é o primeiro. O primeiro genótipo a ser trabalhado."

G18 - "Pela primeira etapa, tipo, genótipo é a parte de onde surgiu as outras características. "

G26 - "A partir de onde surge a variabilidade onde vai poder agir a mutação, a seleção natural e dar a adaptação da espécie." 
De todos os entrevistados apenas os estudantes G20 e G21 responderam com certa segurança à questão e justificaram conhecer o assunto por estarem estagiando em uma determinada área que utiliza esse conhecimento.

G20 - "Tudo o que, ... por exemplo, a gente tem uma mutação, a gente tem uma grande família com uma mutação, a mutação é a mesma para todos. É um efeito fundador, então quer dizer, uma pessoa trouxe e começou, foi a partir dela que todas as pessoas nas gerações subseqüentes acabaram tendo o material genético mutado. É uma origem só, então é uma alteração, não necessariamente uma mutação, acho que uma alteração que tem uma origem única e não diversas. A gente pode ter uma doença que tem, por exemplo, num pais, efeito fundador, aquela mutação foi trazida por uma pessoa só e não por ela ter várias origens, ela se origina em momentos diferentes, mutações novas a cada momento, não é assim."

$\mathrm{G} 21$ - "Tem a ver com ... quando um indivíduo ou poucos de uma mesma população se desgarram e chegam numa nova região e fundam. Deriva genética, né. Acho que tem a ver com isso. Aí eles carregam uns poucos alelos e é o que existe naquela população."

\section{II.4 - Conceito e localização do DNA}

Ao solicitarmos que os estudantes falassem sobre o DNA, esperávamos que discorressem sobre o modelo da dupla-hélice, sobre a constituição química, sobre a função e sobre sua localização. Não encontramos quem dissesse não saber nada sobre o DNA, mas muitos estudantes falaram apenas de sua localização na célula, considerando-o como restrito exclusivamente ao núcleo celular.

G01 - "Ele fica dentro do núcleo da célula, ... eu acho; só no núcleo."

G03 - “O DNA fica no núcleo, só no núcleo." 
Houve estudantes que responderam de maneira mais satisfatória, dentro do esperado, mas ainda assim, alguns cometeram equívocos. Continuamos aqui com estudantes que ainda atribuem a localização do DNA exclusivamente ao núcleo, enquanto outros .citam o DNA mitocondrial, de cloroplastos e bacteriano. Encontramos também estudantes descrevendo nucleotídeos.

G02 - “O DNA está no núcleo, só no núcleo. Ele vai mandar produzir as proteínas através dos ribossomos. Eu sei que ele faz isso, mas não lembro como faz para chegar do DNA para os ribossomos."

G04 - "O DNA está no núcleo e na mitocôndria , acho que nos cloroplastos também tem. Agora eu só não sei se ele está no ... ou se é no ribossomo ... Tem uma coisa de nucleotídeos ... é aquela seqüência lá de adenina, timina ... Acho que cada três vai formar uma enzima, é isso?"

G07 - "Tem nucleotídeos que é a ribose, a base nitrogenada e o fosfato. A seqüência de bases nitrogenadas conseguem transcrever para um RNAm e para uma molécula de proteína. O DNA fica no núcleo da célula, só no núcleo."

G08 - "Açúcar com base nitrogenada e fosfato que juntos formam a cadeia de açúcares. Fica no núcleo e nas mitocôndrias. As bactérias têm DNA circular."

G10 - "O DNA é onde está armazenado o que a gente vai ser, todas as características que a gente apresenta no nosso corpo e tudo está armazenado ali. É ele que vai falar como as proteínas devem se organizar; vai determinar quais são os aminoácidos para dar origem a determinados tecidos; ele é meio que o provedor. Ele fica no núcleo da célula, na gente só no núcleo e nas bactérias fica disperso no citoplasma."

G11 - "Lembro das bases, dos nucleotídeos. Lembro que A liga com T e C com G. Algumas coisas como mutações, algumas funções celulares, lembro daquele 
desenhinho que tem o tipo de aminoácido, o tipo de bases ligadas. Lembro vagamente. Ele fica no núcleo, só no núcleo da célula."

G16 - "É como se fosse a sua origem, de onde vai sair, vai expressar todas as coisas que vão formar um organismo. É como se ele fosse o segredo, melhor dizendo, é como se fossem as regras do jogo. É dali que vai ser feito todo o organismo, porque a partir do que o DNA determinou, vai acabar resultando em uma proteína. A cópia dele e tal vai dar em uma proteína e as proteínas são estruturais e elas compõem muitas das células e outras macromoléculas, mas as proteínas são de característica mais funcional. Eu acho que o DNA é o que vai formar tudo. Ele fica no núcleo, só no núcleo."

G17 - "Dupla-hélice, A,T,C,G, para se dividir ele abre, ai soltam várias bases e eles podem formar dois. É responsável pelas funções ... Todos os seres vivos têm dentro do núcleo da célula."

G18 - "Uma molécula tridimensional, ela tem uma dupla-hélice. Ela tem uma replicação semiconservativa. Ela é o material genético da célula. Ela faz o genótipo que vai expressar as características fenotípicas de algum organismo de uma forma geral e fica dentro do núcleo. Tem o DNA mitocondrial, mas acho que ele é mais presente em células germinativas femininas. A germinativa masculina tem, mas acho que ela perde no momento da fecundação, porque tem uma perda dessas células mitocondriais. O DNA mitocondrial é circular e o DNA nuclear é espiraladinho. Bactéria também tem DNA circular."

O estudante G23, afirmou que no caso dos vírus , " o DNA fica dentro da célula dos vírus".

G23 - "Pode estar no núcleo da célula. Em eucariontes só no núcleo. Aí em procarionte, como não tem núcleo fica lá dentro da célula. No caso de vírus, quando é vírus fica lá dentro da célula do vírus. O DNA é o responsável por 
fazer a célula funcionar. É o centro de informações da célula e o DNA ... Eu fico pensando, como será que surgiu uma coisa tão complexa como o DNA, ta lá com todas essas informações... É dificil de acreditar!”

Encontramos estudantes que responderam além do que esperávamos, abordando íntrons, exons, ligações do tipo pontes de hidrogênio, DNA "lixo", duplicação semiconservativa dentre outros conceitos citados.

G12 - "Seqüência de nucleotídeos, que são diferentes pelas bases nitrogenadas adenina, timina, citosina e guanina, e que elas são arranjadas em dupla hélice. São pontes de hidrogênio entre cada base, como se fosse uma escada. Os degraus são as pontes de hidrogênio de AT, CG. No DNA estão guardadas todas as informações genéticas e os segmentos que codificam essas informações são os genes. Só que a minoria do DNA, por volta de uns $10 \%$ codifica genes, tem a parte inferior e superior, para saber onde começa e onde termina o início da transcrição de cada gene. Dentro dos genes estão os introns e os exons, os exons codificam mesmo e os íntrons não. Eles serão eliminados na transcrição, não serão traduzidos. O DNA fica no núcleo celular, nos cromossomos. O cromossomo é uma molécula de DNA envolta em proteínas chamadas histonas, essas proteínas são octâmeros, aí elas vão se enrolando até chegar na metáfase onde dá para melhor visualizar. Além do núcleo tem DNA na mitocôndria e nos cloroplastos e só em eucariontes. Nas bactérias o DNA forma os plasmídios."

G20 - “Está localizado no núcleo da célula, não só no núcleo, mas também no interior da mitocôndria. Ele é responsável pela codificação das proteínas que executam várias funções no nosso corpo. Então, basicamente, todas as coisas do nosso corpo, ou quase todas, muitas coisas do nosso corpo são executadas por proteinas. Tem uma parte do DNA que não tem aparentemente função. É uma parte do DNA que não se sabe ainda se codifica. Se sabe que ele não é codificante de genes, mas não se sabe o que ele faz, é uma porcentagem bem grande do DNA. É uma dupla-hélice, está dentro do núcleo e fica bastante 
condensado. Estou falando do DNA nuclear, ele se associa a proteínas dentro do núcleo também. Quando vai acontecer a transcrição e a tradução, ele tem que se soltar das histonas, porque ele está muito ... ele se modifica para poder transcrever, porque senão não dá para transcrever.”

G30 - "O DNA é uma molécula que tem uma forma de dupla-hélice.Ele é formado, por uma base nitrogenada, uma pentose, uma partícula de açúcar e um grupo fosfato. Essas bases no DNA só podem ser quatro, que é adenina, timina, citosina e guanina. Pelas características dessas bases ele se constitui em um código, que as células podem replicar e ler esse código. É a molécula utilizada para guardar as informações da formação dos seres vivos em geral. Ele fica dentro do núcleo ou fica pelo citoplasma da célula, vai depender se a célula tem ou não núcleo. Tem também DNA mitocondrial e DNA de cloroplastos, mas são pedacinhos pequenos e aí esses pedaços de DNA vai ser específico para proteínas de cloroplastos e de mitocôndrias."

\section{II.5 - Relação entre DNA e aminoácidos}

Quando perguntamos aos estudantes o que eles lembram quando ouvem DNA e aminoácidos e se há relação entre eles, apenas um estudante, dos trinta e três entrevistados responde que não sabe. Isso faz sentido, pois os termos DNA e aminoácidos são abordados em diversas disciplinas do curso e, mesmo que o estudante não consiga relacioná-los, pelo menos em algum momento já ouviu falar. Mas, encontramos diversos graduandos que confundem os conceitos relacionados ao DNA, fazendo relações completamente inadequadas.

G12 - "Não sei ao certo."

G01 - "Acho que dá para seqüenciar as bases do DNA por meio dos aminoácidos. Essa é a relação que consigo fazer." 
G10- "O DNA é um complexo de ácidos desoxirribonucléico com determinada proteína, que eu esqueci o nome, como os aminoácidos formam as proteínas eu acho que está nessa base o relacionamento deles."

O estudante G04 diz que os ácidos nucléicos se transformam um no outro, ou seja, que DNA se transforma em RNA ou vice-versa, ele afirma não ter certeza de quem se transforma no outro. Esse depoimento evidencia que o estudante não tem domínio do processo de transcrição, pois para ele ocorre transformação de um ácido nucléico em outro e não que o DNA atua como molde para o RNA.

G04 - "Não sei muito bem, mas acho que um transforma o outro, mas quem fazia isso, quem estava lá primeiro, se era o DNA ou o RNA, eu fico na dúvida. Não sei direito quem se transforma em quem."

O conceito de nucleotídeo também é outro ponto de desconhecimento dos estudantes. Verificamos que muitos nem sequer citam os nucleotídeos, enquanto outros fazem relações completamente inadequadas entre os termos. Percebemos um relativo incômodo nos estudantes por sentirem dificuldades em responder às questões, pois acreditam que por estarem no último semestre do curso têm o domínio dos conceitos mínimos exigidos para a formação de um biólogo, mas no decorrer das entrevistas percebem as dificuldades e alguns demonstram certo nervosismo e chegam a verbalizar a decepção e desculpar-se.

G11- "O aminoácido faz parte do DNA. Eu não sei bem a profundidade da coisa, mas eu sei que ele está lá. Acho que ele forma as bases nitrogenadas."

G15 - "O DNA vai dar a seqüência de nucleotídeos para formar um aminoácido."

G16 - "Na verdade eu não sei se as bases do DNA são aminoácidos, mas pode ser considerado alguma coisa assim, mas de qualquer forma o DNA vai transcrever para RNA e o RNA vai passar para os ribossomos e vai sair, e vai traduzir aminoácidos.” 
G17 - "DNA faz o cruzamento sexuado e acabam fazendo aminoácidos."

G18 - "DNA acaba fazendo RNA por causa do DNA complementar que vai desenvolver a tradução das proteínas, então está os dois relacionados."

G24 - “O DNA é formado por aminoácidos.”

G25 - “O DNA tem o RNA ... não lembro agora, tem um outro. ODNA ... eu não sei os termos certos, olha só que vexame. A partir do DNA é formado o RNA eu não lembro se era o mensageiro ou se tinha um antes, enfim e dai depois liga com os aminoácidos."

G29 - “O DNA é formado por quatro aminoácidos básicos, que é a adenina a guanina, citosina e ... esqueci ..."

G31 - "O aminoácido ... um códon, né, cada três bases formam um códon para um determinado aminoácido.”

Encontramos estudantes que respondem de maneira simplista e bastante superficial, pulando etapas do processo. Isso evidencia insegurança nas respostas ou desconhecimento do assunto, sendo assim, preferem falar pouco para não correrem o risco de responder de maneira equivocada.

G13 - "O DNA é para formar as proteínas. O DNA vem o RNA e depois forma as proteínas."

Há aqueles que tentam responder de maneira mais completa, fazendo relações, mas utilizam explicações do senso comum, sem embasamento científico, ou ainda, tentam explicar de maneira completa, mas se perdem no caminho.

G19 - “A relação que eu faço é que o DNA, a estrutura dele tem proteínas que não deixa de ser aminoácidos também, histonas, etc. Se não tiver o DNA eu acho 
que não tem como fazer uma proteína, porque os aminoácidos dependem de uma codificação do DNA."

G20 - "Não há uma ligação tão direta entre eles, não é direta como a ligação do DNA com o RNAm, mas nada mais é do que a ,... é o produto final daquilo, ... é quase o produto final, do que tem o gene, é o que vai estar na proteína, então é a ligação gene-proteína."

G23 - “O DNA tem os códigos que vão falar qual o aminoácido vai ser inserido na proteína, mas ai tem que ter o RNA no meio para agir, nessa cadeia toda tem o RNA também."

G27 - "O DNA é uma molécula que está dentro do núcleo da célula, que tem as informações genéticas que ... e as informações que geram as proteínas e as proteínas são formadas por aminoácidos."

G33- "Você tem os códons, tem o código genético, com as três basesinhas nitrogenadas e a partir disso você sabe qual vai ser o aminoácido que vai ser chamado lá pelo transportados, pelo RNAt."

Encontramos estudantes que em poucas palavras conseguiram explicar bem, usando uma linguagem cotidiana e relacionar adequadamente os conceitos, outros ainda foram capazes de formular respostas muito bem elaboradas, fazendo uso da linguagem científica.

G14 - "O DNA tem um código genético que vai determinar a seqüência de aminoácidos.”

G26 - "No DNA é codificado as informações da seqüência dos aminoácidos que vão formar a proteína." 
G22 - "No DNA é que tem a "receitinha" de como os aminoácidos vão ser agrupados."

G21 - "A relação é o código genético, no qual três bases nitrogenadas correspondem a um aminoácido ou nenhum, como no caso de uma parada, ou ainda um aminoácido pode ter mais de um códon."

G28 - "O DNA nem sempre tem essa função, mas quando ele é codificante para proteína, é como se ele codificasse numa linguagem mais estável, que serão as proteinas que vão ser produzidas no indivíduo. Os aminoácidos são a base das proteinas."

$\mathrm{G} 30$ - "É o DNA que vai estar guardando essas informações em um código que depois de um longo processo de transcrição e tradução, o resultado vão ser as proteinas. Os aminoácidos entram na formação das proteinas."

G32 - "No DNA está a informação básica que vai determinar qual vai ser a seqüencia de aminoácidos da proteína."

\section{II.6 - Conceito de RNAm, aminoácidos e proteínas}

Perguntamos aos estudantes o que eles lembram quando ouvem RNA mensageiro, aminoácidos e proteínas e como eles se relacionam. Não encontramos nenhum estudante que verbalizasse que desconhece algum dos conceitos questionados. No entanto, dois estudantes responderam de maneira completamente inadequada, confundindo os conceitos de tradução e transcrição. Fica evidente para a pesquisadora que os estudantes já tiveram contato com os conceitos, mas que os mesmos não fazem parte de sua rede conceitual, pois as respostas são confusas e sem sentido. 
G11- “A mensagem, o código, as seqüências que é interessante. Ele que transfere para as células, ele que leva a informação e ele que ajuda a formar os genes e os aminoácidos também fazem parte desta cadeia, fazem parte dos genes."

G13 - "Transcrição gênica, formação de proteínas. O RNAm que vai formar as proteinas. Tem o DNA depois o RNAm que vai formar os ribossomos com o RNA ribossomal e depois o RNAt que vai formar as proteinas.”

G14 - “O RNAm vai fazer a transcrição. Do DNA ele vai levar uma mensagem para o citoplasma aonde essa mensagem vai ser decifrada. Aí ele que vai dar a ordem dos aminoácidos para formar as proteínas."

G16 - "O RNA é o precursor de uma coisa que vai virar proteína, quer dizer, ele é precursor da proteína. Ele é a cópia do DNA que depois vai ser traduzida em três aminoácidos e uma proteína é o conjunto de aminoácidos. "

G25 - "RNAm é que uma seqüencia de bases que passa pelos ribossomo, a cada três bases ele forma um códon e cada códon, ... não cada códon, um aminoácido pode ter vários códons ... é difícil explicar ... mas aí que liga um aminoácido a cada, ... não liga, o ribossomo vai ... não lembro direito, mas enfim, um códon dessas três bases ai é igual a um aminoácido e o conjunto de vários aminoácidos é igual a uma proteína."

G28 - "RNAm ele faz com que os aminoácidos trazidos pelos códons se encaixem na fita dos ribossomos e aí são produzidas proteínas."

Para a maioria dos estudantes a relação entre RNAm, aminoácidos e proteínas não está bem clara Percebe-se uma lacuna no conhecimento dessas relações no decorrer das entrevistas; os estudantes não conseguem explicar os processos de transcrição e tradução, mas, apesar disso são capazes de relacionar aminoácidos, polipeptídios e proteínas 
G10 - “Aminoácido é o primórdio, vários aminoácidos dão origem a uma proteína, e a proteína é a base de todos os seres vivos conhecidos e RNAm, ácido ribonucléico, mensageiro ele está envolvido no processo de transcrição, de cópia."

G15 - "Células, transcrição de proteínas. O RNAm vai dar as informações para vários aminoácidos virarem uma proteína."

G17 - "O RNAm fala quais os aminoácidos que tem que pegar e eles se juntam para fazer a proteína. É a combinação de três aminoácidos e vários aminoácidos vai dar a proteína."

G18- "As trincas de aminoácidos vão se juntar ao RNAm para codificar a proteína. O RNAm junto com os ribossomos vão estar codificando as proteínas pela junção dos aminoácidos que vão chegando ao núcleo."

G19 - "RNAm que é o que faz a tradução das bases do DNA. Ele vai formar os aminoácidos e vai formar as proteínas. Ele sintetiza os aminoácidos que vão formar as proteinas."

G26 - "Um RNAm é aquele que é produzido a partir de um DNA e ele traz a informação genética do núcleo para ser traduzido em ribossomos. Ele vai levar a informação, vai levar a receitinha de quais aminoácidos devem ser incorporados para se formar a proteina."

G31 - “O RNAm ele sai do núcleo para ir onde vai ser traduzido, transcrito, não sei bem. Os ribossomos, ... daí vai fazer com que os aminoácidos se juntem para fazer as proteinas."

Em contrapartida, encontramos estudantes que demonstram conhecer os conceitos e também são capazes de fazer relações válidas entre os diversos conceitos. 
G20 - "RNAm é a ... ele faz a ligação entre a linguagem do gene e a linguagem que o corpo vai conseguir entender. É a ligação entre gene e proteína que é formada por aminoácidos. Tem o DNA, o RNAm e daí os aminoácidos se ligam nos RNAt para codificar, para produzir a proteína."

G21 - "Síntese de proteína. O famoso modelinho de sintese protéica. O RNA é transcrito a partir de um gene no núcleo, a partir de enzimas que atuam no núcleo, esse RNAm passa pelo poro nuclear, chega no citoplasma onde, eventualmente, encontra a subunidade menor do ribossomo que, eventualmente, encontra a subunidade maior do ribossomo e inicia a tradução dessa proteína com o auxílio do RNAt e aí é que entram os aminoácidos."

G24 - "RNAm é tipo um molde que sai do núcleo e vai para o citoplasma. Ele vai ser, com os aminoácidos, vai ser montado uma proteína e o RNAm é o molde para produzir essas proteínas."

G27 - “O RNAm é a molécula que dá a informação para a síntese de proteínas. As proteínas são formadas pelos aminoácidos. As proteínas são muito importantes para o nosso organismo, para qualquer ser vivo, elas são a base da maquinaria celular e o RNAm é que traz o DNA ... ou melhor, é a ponte entre o DNA, onde está a informação genética até a síntese de proteínas. São as efetoras, digamos assim."

G33 - "Eu lembro de sintese de proteínas. O RNAm vai ser uma, ... vai existir uma transcrição a partir do DNA e ele vai levar os códons até o ribossomo e lá o ribossomo vai chamar o RNAt e vai pegar os aminoácidos e construir uma proteina. Essas coisas se relacionam assim a informação que está no núcleo é transmitida, é decodificada, vai para o citoplasma através do RNAm e aí esse dois materiais, aminoácidos é uma pequena parte da proteina e está relacionado ... é o processo de construção da proteína." 


\section{II.7 - Relação entre aminoácidos e polipeptídios}

Perguntamos aos estudantes o que eles lembram ao ouvir as palavras aminoácidos e polipeptídios. Alguns estudantes responderam que não sabem ou não lembram. Encontramos estudantes que tentaram responder pela definição etimológica da palavra, mas não conseguiram chegar à uma resposta satisfatória.

G03 - "Não sei o que é um polipeptídio... aminoácido talvez seja... não sei."

G05 - "Poli é muito...vem de vários...mas vários o quê?"

G15 - “Eu não lembro.”

Alguns entrevistados sabiam explicar apenas um dos conceitos perguntados ou, as respostas eram incompletas ou ainda insatisfatórias sob o ponto de vista científico.O estudante G11 confunde proteínas com carboidratos, enquanto o estudante G30 responde utilizando conceitos do senso comum para explicar o que são polipeptídios.

G04 - "Vários aminoácidos vão formar uma proteina e vários polipeptídios podem formar uma proteina."

G10 - "Aminoácidos são unidades das proteinas e polipeptídios é a união de vários peptídeo."

G11 - "Polipeptídio ... Eu não lembro se o aminoácido faz polipeptídios ou se polipeptídio faz aminoácidos. Espera aí ... Acho que tenho uma vaga idéia. Acho que tem os monossacarídeos, dissacarídeos... Ah, não lembro."

G14 - "Os aminoácidos formam as proteinas. Se essa proteína tem vários aminoácidos ela pode ser um polipeptídio." 
G18 - "Vários polipeptídios vão formar um aminoácido."

G22 - “Aminoácidos é um pedaço de proteína, fragmento de proteínas. Polipeptídios são muitos aminoácidos."

G25 - "Aminoácidos é o que forma a proteína e o polipeptídio ... não sei."

G30 - “Aminoácidos lembro de proteínas e polipeptídio são proteínas pequenininhas."

Encontramos estudantes que responderam adequadamente à questão de maneira simples e objetiva. Outros, no entanto, utilizaram uma linguagem mais elaborada e responderam de maneira mais completa.

G09 - "Polipeptídios são vários aminoácidos."

G17 - "Polipeptídio é formado por vários aminoácidos."

G12 - "O aminoácido é um monômero, polipeptídio é um polímero. Cada ligação de aminoácido é uma ligação peptídica entre o grupo amina e o ácido carboxílico e ocorre a liberação de uma molécula de água. Entre vários aminoácidos são várias ligações peptídicas e formam o polipeptídio que forma uma proteina."

G20 - "De ligação de carbono, nitrogênio e hidrogênio e alguns outros grupos se unem. Eu lembro basicamente de proteina, de coisas que se unem para originar uma proteína. Polipeptídio não é o que a gente costuma pensar logo que ouve aminoácido. È a reunião de aminoácidos não tão grande, uma reunião de aminoácidos dando uma cadeia não tão grande para ser considerado uma proteína." 
G29 - "Aminoácidos lembro de subunidades de proteínas. Polipeptídios lembro de uma cadeia de aminoácidos."

G32 - "Aminoácido lembro de proteínas. E polipeptídios também lembro de proteínas $O$ que eles têm de diferente é o número de aminoácidos que estão agrupados. $O$ aminoácido seria uma unidade e o polipeptídio seriam vários aminoácidos depende do número de aminoácidos que estão ligados.”

É interessante perceber na resposta do estudante G24 que a aprendizagem ocorreu por meio do uso de modelos e que mesmo tendo se passado muitos anos, ele ainda é capaz de lembrar-se da atividade e consegue relacioná-la ao conceito questionado.

G24 - "Lembro de um esquema de quando eu estava no colegial que a gente fez com clipes, era para ver isso da produção do RNAm., aminoácido e tal. Eu lembro dos esqueminhas que era um negócio com clipes, cada aminoácido tinha um clipes para um lado para o outro. Eu só lembro desse esqueminha que eu fiz na escola. Aminoácido forma a proteína. Polipeptídio é um conjunto de aminoácidos que tem um certo número considerável, eu não sei se é mais de cem. Tem um número que eles consideram para ser polipeptídio."

\section{II.8 - Conceito de retrovírus}

Pedimos aos estudantes que falassem sobre retrovírus. Nos chamou a atenção o fato de um grande número de estudantes, dez em trinta e três entrevistados, o que corresponde a 30,3\%, afirmarem que desconhecem o que seja um retrovírus.

G02 - "Não tenho a menor idéia do que seja."

G03 - "Não lembro... não sei."

G04 - "Não sei o que é. Talvez seja um RNA, retrotranscrito... sei lá!” 
G10 - "Não sei o que é retrovírus. É o vírus que... não sei."

G14 - "Não sei te dizer. Lembro de palavras, mas não lembro de nada, nenhuma doença, nada sobre ele."

G16 - "Uma coisa que tem a ver com vírus obviamente, não sei qual que é a diferença de um vírus para um retrovírus."

G18 - "Nada. Acho que pode ser algum mecanismo de proteção, algum mecanismo de ... acho que proteção mesmo."

Encontramos estudantes que tentaram de alguma maneira explicar o que seria um retrovírus, mas, no entanto, não conseguiram responder de maneira satisfatória.

Encontramos quem confundisse retrovírus com bactéria, com hospedeiro e ainda quem afirma que retrovírus é um vírus mais ou menos, ou seja, para esse estudante um retrovírus não é um vírus e sim algo "quase vírus".

G01 - "Retrovírus é uma bactéria ! É uma virose!"

G05 - “Acho que é um hospedeiro. Ele não tem material genético. Ele usa o material genético da célula."

G31 - "Virus. Um vírus mais ou menos, só!”

O estudante G07 confunde o conceito de retrovírus com o de bacteriófago, mas parece não estar certo disso e depois muda de idéia e responde corretamente à questão. Pela maneira como respondeu à pergunta, mesmo no final tendo respondido satisfatoriamente, o estudante estava extremamente inseguro e não tinha certeza do que estava falando.

G07 - "Retrovírus é um vírus que entra em uma bactéria e a partir dela ele se multiplica usando o material genético dela e ele sai como ... Não, isso não é retrovírus. Retrovírus é um vírus de RNA, tem só RNA, eu acho." 
O estudante G25 também consegue responder adequadamente o conceito de retrovírus, no entanto em sua resposta notamos muita insegurança .

G25 - “Eu lembro que tinha dois ... o retrovírus é o de RNA, não é? Eu acho que é o vírus que tem o ... Bom, todos os vírus são de RNA. Não, não são. Retrovírus é o vírus com RNA, acho que é isso."

Encontramos vários estudantes que conhecem o conceito de retrovírus e responderam de maneira simples, objetiva e adequada, alguns chegam a citar a enzima transcriptase reversa, enquanto outros não.

G09 - "Virus com RNA. A transcriptase reversa converte o RNA em DNA."

G11 - "Ele consegue a partir do RNA formar o DNA dele. Ele faz o caminho inverso. Eles são muito usados em algumas pesquisas, como câncer, por exemplo."

G20 - "Virus que é capaz de sintetizar DNA a partir de RNA, então o material genético dele é RNA e ele sintetiza o DNA a partir do RNA. É a transcrição reversa."

G23 - "Virus de RNA, que pega ... que nem o vírus da Aids e da gripe."

G26 - "Virus que tem o RNA e a partir dele ele produz o DNA."

G27 - "São vírus que tem RNA como material genético."

G22 - "HIV, não lembro direito. Acho que é o vírus que forma o DNA a partir do RNA.”

Alguns respondem de maneira mais elaborada, utilizando corretamente a linguagem científica. 
G12 - "Virus da Aids. É um vírus de RNA, ao invés de uma cadeia de DNA ele tem uma cadeia de RNA e quando ele entra na célula tem também uma enzima que chama transcriptase reversa que usa o DNA da célula só que para transcrever o RNA dele. Então ele usa o DNA da célula para transcrever com a transcriptase reversa, ai vira um DNA, esse DNA que ele fez a partir do DNA da célula e da transcriptase reversa codifica a proteína para a cápsula dele e forma outros e também para codificar, duplicar."

G24 - "Eles tem transcriptase reversa, que é a enzima que ... Esse retrovírus tem RNA como material genético,e então eles usam . a transcriptase e conseguem fazer com que o RNA do material genético do vírus seja o molde para produzir um DNA. É o contrário, né. Então a gente usa o nosso DNA como molde para fazer o RNA e nos retrovírus é o contrário."

\section{II.9 - Conceito de transcrição e tradução}

Com o objetivo de evitar definições decoradas de conceitos e verificar se ocorreu aprendizagem significativa dos conceitos de transcrição e tradução, utilizamos como recurso uma analogia. O estudante recebia uma folha com a "história" e era orientado para que relacionasse a "historinha" recebida com o funcionamento de uma célula. A analogia utilizada nas entrevistas foi a mesma empregada nas questões 4, 5 e 6 do ENC-BIO/2002. A "história” utilizada está em destaque no quadro abaixo.

João trabalha em uma confeitaria cujo proprietário é alemão. Todas as manhãs este deixa, sobre a mesa da cozinha, uma receita em português e os ingredientes de um bolo que João deve preparar. A receita original, escrita em alemão, fica guardada no escritório da confeitaria. Somente o patrão de João pode abrir o escritório e escrever, em português, a receita a ser utilizada naquele dia. Alguns bolos são servidos assim que saem do forno, enquanto outros recebem um acabamento especial, como por exemplo, recheio e cobertura. 
Encontramos estudantes que apresentaram grandes dificuldades em relacionar a "história" recebida ao funcionamento celular. Um deles declarou ser muito difícil e por desconhecer os conceitos não conseguia fazer as relações adequadas.

G02- "É muito difícil, eu não sei os conceitos, então não consigo fazer as relações."

Em outros casos, os estudantes tentavam fazer relações, mas, sob o ponto de vista científico, estas eram inválidas ou muito superficiais.

G03 - "Para mim as partes mais importantes de uma célula são o núcleo, então eu acho que o núcleo é o escritório. O citoplasma eu não dou muita importância, então poderia ser a cozinha e o João deve ser os cromossomos."

G04 - "O bolo seria o aminoácido, os ingredientes seriam os nucleotídeos, a receita em português seria o DNA e a receita em alemão seria o RNA.'

G05 - "O escritório seria o João, a cozinha seria o citoplasma e os ribossomos seriam o núcleo. O ribossomo serve do $R N A \ldots$ do DNA..."

G06 - "Eu acho que a receita é o DNA..."

G07 - "O local da confeitaria onde recebe recheio, cobertura e acabamento eu pensei no retículo endoplasmático rugoso, porque como eu pensei que a proteína vai sair do retículo eu acho que algumas ficam armazenadas ali."

G11- "Eu acho que está ligada a parte do RNAm que a gente falou, que ele entrega a receita. Tem a receita original, que eu acho que é o da fita 3'/5' que vai se formar a outra, que acho que seria o bolo, não sei ... E acho que o que poderia ligar alguma coisa de respiração da célula, da mitocôndria, da respiração celular, produção de energia. Tem sempre uma "receitinha". A 
respiração celular entrega energia, alimento e eles devolvem energia, glicose, e tal. Dá pra ligar com várias coisas."

G16 - "O proprietário alemão seria o DNA dai ele tem bases que formam o DNA que é a receita original. O formato do DNA seria a receita original que é no caso, a receita em alemão. O proprietário alemão, que é o patrão de João seria os fatores que fazem a célula entrar em divisão, replicar o material genético. $O$ resultado disso seriam as proteínas, que cada uma serve para uma coisa, então, por exemplo, o bolo com acabamento especial seria, por exemplo, uma proteína estrutural, o outro que serve de recheio, seria proteína ... ah, os vários tipos de proteinas, analogamente assim cada acabamento seria para que função ela iria exercer no organismo.O acabamento especial dos bolos aconteceria no núcleo ... A proteína ... acho que seria no citoplasma, mas não sei ao certo onde ocorre."

G17 - "Funcionamento da célula. Proprietário é o DNA, o João ele traduz ... não, mas é ele que traduz. O proprietário traduz e os bolos podem ser as proteínas que são usadas imediatamente ou são usadas depois."

Encontramos, também, estudantes que fazem algumas relações adequadas entre alguns personagens da "história" e estruturas celulares e seu respectivo funcionamento, porém no decorrer das respostas aparecem confusões conceituais e relações completamente inadequadas.

G10 - “A confeitaria seria a célula ou o núcleo, não sei. A receita ... O escritório da confeitaria é o núcleo celular, a receita original escrita em alemão é o DNA, a receita em português seria o RNA. O patrão de João é algum tipo de RNA, não sei se é o mensageiro ou outro, agora o bolo eu não sei se representam os genes que vão expressar alguma coisa, acho que é isso." 
G13 - "A receita que está no escritório é o DNA, a receita em português é o RNAm que vai transcrever a proteína e a proteína é o bolo. O recheio e a cobertura são alguns genes vitais que servem para a variabilidade genética."

G14 - “O patrão seria o DNA, a receita seria ... não ... O João seria o RNAm, a receita seria a mensagem. O bolo seria as proteínas produzidas, sendo que algumas seriam logo utilizadas do jeito que são e as outras passariam por alguma transformação, alguma mudança. Essa transformação eu acho que ocorre no local onde elas ficariam estocadas, não lembro o nome do local."

G15 - “O alemão tem que ser o núcleo, o João ele é um ... seria o proprietário com a receita original que é o alemão. A receita ela é ... a receita original ela está em alemão, então ela é um ... Espere um pouco. Os ingredientes são os genes, os aminoácidos e bases que vão formar a receita, que vão formar uma cadeia de proteínas, que vão fazer o bolo que seria uma proteína ou um pão. Os cromossomos têm que estar dentro pra poder dar a informação que vai mandar para uma organela que seria um lisossomo, que seria a cozinha. Na cozinha iria fazer o bolo através do RNAr. O bolo seria a proteína que seria formada. O recheio e a cobertura seria ... uma proteina e o outro seria enzima. O acabamento especial eu não sei onde é dado."

G24 - “O funcionário ... o proprietário da confeitaria, o alemão, só ele que tem acesso às receitas originais dos bolos, então, eu não lembro se é RNA polimerase ou DNA polimerase, eu não sei os nomes das enzimas, sou péssima para nomes, mas eu faria uma analogia do proprietário com quem vai lá no núcleo e faz o RNAm, quem lê o gene e produz o RNAm que vai ser lido no citoplasma, que seria o João, né. O João seria o cara que iria formar, pegar o RNAm no citoplasma e ele que iria formar as proteínas e, quem sabe, talvez dar o acabamento final."

G25 - “O João é ... o alemão é o núcleo, ou tem que especificar acho que ele é o cromossomo. Acho que não é bem isso, né. A receita em português acho que 
seria o RNA, bem esse aqui será que é o RNA ou o DNA. Bem não importa, acho que é o núcleo, porque é organela.Uma receita em português que deve ser o RNAm e os ingredientes seriam os aminoácidos. A receita original escrita em alemão seria o DNA, que fica guardada no escritório da confeitaria, cromossomos ou o núcleo devem ser ... ah, não sei. O patrão de João pode abrir o escritório e escrever em português a receita, alguns bolos são as proteínas, eu acho, agora quando recebe recheio e cobertura, não sei."

G27 - “A receita original seria o DNA que somente ... que está em outra língua, né. O alemão seria o mensageiro, o RNAm, seria a enzima, sei lá, que lê que faz ... O RNAm seria a receita em português. É ela que o confeiteiro, o João, que talvez seria o ribossomo, estaria fazendo, que seria a sintese da proteína que seria o bolo. Então, assim, o DNA seria a receita em alemão, o alemão seria a enzima que traduz, não que traduz, mas que passa do DNA para o RNA $\mathrm{m}$, que seria a receita em português e o João seria o ribossomo, as enzimas dos ribossomos que fazem o bolo, que seriam as proteínas. E algumas são ... alguns bolos são servidos assim que saem enquanto outros recebem acabamento, que depois que a proteina é sintetizada pelos ribossomos ela pode sofrer algumas mudanças, algumas alterações no retículo endoplasmático, retículo ..., acho que é endoplasmático, sei lá. Sofre algumas mudanças, tira partes, ou coloca algumas partes."

G28 -“A receita original do bolo é o DNA que fica guardada no escritório da confeitaria que é o núcleo e o patrão do João que abre o escritório e escreve é a polimerase e ai ele escreve em português, que é o RNAm, ele é a receita em português que o João vai utilizar. O João é o ribossomo e alguns bolos são servidos assim que saem do forno, que é quando o RNA não sofre nenhuma transformação pós-transacional, enquanto outros recebem acabamento especial que é a edição do RNA. O bolo representa a proteína, eu acho ... Daria para ser o RNA, mas se ele é servido assim que sai do forno ... Porque você pode ter edição do processo de duplicação de proteínas tanto 
a nível pós traducional quanto pós-transacional. Então o bolo é a proteína porque dá para você editar uma proteína, você corta, você glicosila ..."

G32 - “A receita original poderia ser o DNA, o alemão é o RNAt que vai lá pegar a receita para transcrever. $O$ alemão pode ser o transportador, o João seria o RNAm e os ingredientes poderiam ser os aminoácidos que estariam no bolo, que seria a proteina."

Houve estudantes que conseguiram relacionar de maneira adequada todos os conceitos abordados às situações da "historinha".

G12 - “Aqui está falando que a receita é traduzida do alemão para o português para dai ele fazer o bolo. É a mensagem do DNA que é transcrita para o RNA e o $R N A$... É como se a mensagem em alemão fosse o DNA que é transcrito para o RNA e depois ela é traduzida para proteína. A receita original é o DNA. A tradução é o RNA porque é ele que lê o DNA, só ele. O proprietário que é alemão, só ele consegue ler a receita e traduzir para o português, que é o RNA. E a síntese disso que está escrito lá que vai ser formado seria o bolo. Algumas proteínas que são transcritas são usadas daquele jeito, outras podem receber outras ... Por exemplo, uma proteína que é uma enzima pode ser usada daquele jeito, outra proteína que vai formar outra coisa dentro da célula pode receber, sei lá, pode formar uma glicoproteína depois. As proteínas são produzidas nos ribossomos, que são grudados no retículo endoplasmático. Tem lá uma preparação, uns cortes, depois vai para o complexo de Golgi que segrega elas e adiciona o que vai ser adicionado e algumas saem em vesículas que são os lisossomos."

G19 - "O alemão seria o DNA, que é o proprietário. A confeitaria seria a célula, ou talvez o núcleo. O João seria o RNA. O alemão que é o patrão que escreveu, seria o código do DNA, o João precisa codificar isso, então ele seria o RNAm. Acho que algumas proteínas são transcritas para ser utilizadas na hora e outras... O bolo seria a proteína. Enquanto outros recebem 
acabamento especial. Seria uma complementação da proteína porque às vezes ela não é só proteína vai precisar de outras moléculas. O acabamento especial eu não sei onde as coisas recebem."

G20- "O escritório da confeitaria seria o núcleo de uma célula. Os bolos são as proteínas, algumas sendo já utilizadas de pronto e outras que sofrem o processo de maturação, elas não são utilizadas logo que elas ficam prontas, então maturação é assim, elas ainda são processadas depois disso; tem proteína que é glisosilada e tal, então isso é a minha analogia com os bolos, com recheio e cobertura. A receita original seria o que está escrito no DNA. É o DNA; o patrão que faz a passagem da receita para o português seria a passagem para o RNAm e o patrão em si, seria ... o João eu acho que é o RNAt, então ele estaria fazendo a mediação entre a receita e o produto final da receita, que é o bolo, então ele seria o RNAt ou os ribossomos. Talvez fique melhor ribossomos."

G21 - “A receita original creio que é o gene. A receita em português, que o João entende é o RNAm, os bolos são as proteinas prontas. Somente o patrão de João pode abrir o escritório e escrever em português a receita a ser utilizada naquele dia. Eu acho que o patrão de João é o material hereditário, o DNA, que controla a síntese protéica. Só ele pode abrir significa que é só uma via, feita pelo patrão do João que sai e chega até João, ao contrário. O bolo seria a proteina pronta."

$\mathrm{G} 22$ - “O patrão de João, o proprietário alemão, é o DNA. O DNA deixa uma receita que é o RNAm. O João é o RNAr, os ingredientes são os aminoácidos, o bolo é a proteína que pode ser de vários tipos."

G23 - "O escritório da confeitaria provavelmente é o núcleo e a receita é o DNA, a receita em alemão. A receita em português deve ser ... O alemão, o proprietário deve ser a enzima ... não, deve ser o RNAm. Ele pega e escreve a receita em português. O João deve ser o RNAr que pega as coisas e vai 
fazendo a receita, no final é a proteína. Aí tem os bolos que quando sai do forno vão ser servidos é a proteína pronta, e outros que vão receber recheio e cobertura podem ser aquelas proteínas que vão ser acopladas a outras na célula, no citoplasma, vão ser utilizadas fora da célula que podem ficar guardadas em algum lugar, nos lisossomos para ir para fora da célula. A cozinha acho que é o citoplasma, os ingredientes são os aminoácidos."

G29 - "A receita original escrita em alemão seria o DNA. A receita em português seria o RNA. O bolo seria as proteínas feitas a partir da receita. Aí ele diz que alguns bolos são servidos assim que sai do forno e outros recebem acabamento especial com recheio e cobertura, porque tem proteinas que são ativas assim que são transcritas e outras só com outros fatores que se tornam ativas."

G30 - "O alemão que é o dono seria o DNA, aí a receita, que na verdade é assim, a receita original que é o DNA que fica guardada no escritório deve ser o núcleo da célula, se for uma célula com núcleo. E aí ... o patrão do João e a receita em português seria a transcrição do DNA que é a conversão do que está escrito no DNA para RNAm, os bolos são as proteínas que algumas recebem fosforilação elas tem outros processos depois que elas são fabricadas, elas ficam ainda no retículo, elas podem ir para o aparelho de Golgi para ali receber outras coisas e depois serem produzidas. E o João deve ser ribossomos, porque é ele que recebe a receita em português e ele fabrica os bolos."

\section{II.10 - Função do Retículo Endoplasmático Rugoso e do Complexo de Golgi}

Perguntamos aos entrevistados para que serve o retículo endoplasmático rugoso e o complexo de Golgi. Encontramos uma parcela consideravelmente elevada de estudantes que não sabiam as funções de nenhuma das duas estruturas citoplasmáticas. Alguns afirmam desconhecimento. 
G01 - “Eu não sei. Já ouvi falar deles, mas não sei pra quê que serve."

G03 - "O complexo de Golgi e o retículo endoplasmático eu lembro que tem uma função muito importante na formação da célula, mas não lembro qual é essa função."

G11 - "Eu não lembro nada daqui da faculdade. Lembro do cursinho e do colégio. Lembro dos desenhinhos. Toda prova eu tentava decorar isso e eu decorava para a prova e depois esquecia. E agora não sei te explicar."

G12 - "Não lembro."

G25 - "Retículo rugoso eu sei que tem um monte de ribossomos, mas não lembro agora para que eles servem."

Encontramos estudantes que tentavam de alguma maneira explicar as funções solicitadas, mas respondiam de maneira vaga, incoerente ou utilizando-se de conceitos inadequados. Houve estudantes que afirmaram que o retículo é responsável por criar ribossomos, outros diziam, ainda, que o retículo produz proteínas.

G02 - "Acho que o complexo de Golgi armazena. Lembro vagamente... o retículo endoplasmático eu não lembro."

G04 - "O complexo secreta enzimas para eliminar. Deve ter mais alguma função, mas eu não consigo lembrar. O retículo endoplasmático eu não lembro mesmo."

G05 - "No complexo de Golgi são fabricados os lisossomos para a fagocitação celular e viral e para a pinocitose. O retículo... sei lá, não lembro." 
G08 - "Retículo endoplasmático rugoso eu não sei. Sei que ele possui ribossomos, mas não sei a função. Complexo de Golgi faz... dá uma arrumada final na proteina."

G09 - "Complexo de Golgi empacota, prepara a proteína para ela ser lançada da célula. Serve para amadurecimento de algumas proteínas de algum... O Retículo eu não lembro."

G10 - "O complexo de Golgi é um tipo de ... ele armazena ... secreção de lipídios ..., não, acho que não é o Golgi ... Ah, eu não sei."

G13 - "Retículo endoplasmático rugoso é que cria os ribossomos que vão produzir as proteínas e o complexo de Golgi eu não lembro."

G14 - "O retículo endoplasmático rugoso é um dos lugares onde as proteínas podem ser armazenadas e o complexo de Golgi eu não lembro."

G16 - "Retículo endoplasmático rugoso tem os ribossomos que vão passar o RNA e sair as proteínas, o complexo de Golgi é muito obscuro pra mim, eu não sei."

G17 - "Tudo aquilo que tem a ver com o funcionamento da célula."

G19 - "Retículo endoplasmático rugoso tem a informação para a transcrição de proteínas e o complexo de Golgi eu não lembro."

G20 - "Retículo endoplasmático rugoso é basicamente síntese de proteína e o complexo de Golgi é para exportar aquilo que o retículo tem que ir para o meio extracelular que não são todas as coisas, então algumas ficam dentro $e$ outras que puderem ir para fora entram no complexo de Golgi que é capaz de exportar para fora." 
G22 - "Complexo de Golgi serve para degradar as proteinas e formar as proteínas em um estágio mais recente. No caso do rugoso para formar as proteínas em um estágio mais avançado. Pelo que eu me lembro sai do complexo de Golgi e vai para o retículo rugoso."

G32 - "Retículo endoplasmático rugoso faz parte da síntese de proteínas que vão ser liberadas para fora da célula. Essa liberação ocorre pelas vesículas do complexo de Golgi.",

Alguns estudantes que entrevistamos responderam a questão de maneira mais satisfatória do que os demais, no entanto, não conseguiram ser claros em suas respostas, sempre havendo alguma confusão ou inadequação conceitual e apenas um dos estudantes relacionou as duas estruturas citoplasmáticas.

G07 - “A membrana do retículo está acoplada aos ribossomos e a proteína fabricada fica ali armazenada e depois é transportada. O complexo de Golgi serve para armazenamento e depois a liberação de lisossomos."

G18 - "Retículo endoplasmático rugoso, ele tem ribossomos e os ribossomos vão estar trabalhando junto com o RNA na tradução da proteínas. O complexo de Golgi seria uma bolsa de armazenamento dos produtos resultantes do metabolismo da célula, tipo o estoque da célula."

G23 - "Retículo endoplasmático rugoso é onde vai ter a montagem das proteínas e o complexo de Golgi é o lugar onde a proteína vai ser secretada para fora da célula."

G26 - "Retículo endoplasmático rugoso, local de armazenamento de substâncias e canais de transporte da célula e complexo de Golgi seria meio que uma continuação do local de armazenamento e formação de vesículas." 
G27 - "Rugoso é...o complexo endoplasmático rugoso ele tem os ribossomos aderidos na sua superfície. E o RNAm ele é lido por esses ribossomos que estão na superfície do retículo endoplasmático rugoso e daí a proteína, quando ela vai sendo formada, ela vai sendo formada nesse retículo endoplasmático e lá dentro elas sofrem essas modificações na estrutura da proteína e daí ela sai desse retículo endoplasmático em vesículas e vai para o complexo de Golgi e lá sofre mais algumas modificações e de lá elas também saem dentro de vesículas. Essas vesículas são fundidas na membrana plasmática e elas vão para fora da célula. Essas são as proteínas extracelulares, agora as proteínas que vão agir dentro da célula não são sintetizadas por esses ribossomos que ficam na superfície do retículo endoplasmático.”

\section{II.11 - Conceito de células somáticas e germinativas}

Perguntamos aos estudantes entrevistados qual a diferença existente entre células somáticas e germinativas. Encontramos apenas um estudante que afirma não saber responder à questão. Todos os demais responderam, mesmo que de maneira insatisfatória. Houve estudantes que tentaram responder, mas acabaram se enrolando nas palavras e não conseguiram êxito em suas respostas. È interessante a postura do estudante G03; ele responde e no final afirma que pensou que sabia a resposta, mas que agora percebe que não sabe. Isso evidencia o fato de que muitas vezes o estudante acredita que sabe os conceitos, quando na verdade não os sabe.

G01 - "Não sei."

G02 - "Eu acho que a germinativa é a que dava origem, que conseguia desenvolver novo ser, tipo reprodução. E célula somática, o que é?"

G03 - "É um termo que todo mundo usa ... Acho que o pessoal usa, por exemplo, assim, não sei se vou estar sendo correta no que eu vou dizer. Você tem o 
espermatozóide e o óvulo; os dois vão formar o embrião e essas seriam as células germinativas dele. Só não me lembro se o óvulo e o espermatozóide juntos formam uma célula germinativa ou se são separados. Somática eu não lembro. Na verdade eu achei que sabia, mas agora percebi que na verdade eu não sei o que são células germinativas e somáticas."

Encontramos alguns estudantes que responderam de maneira incompleta e que no decorrer da entrevista mostraram-se bastante inseguros em suas respostas; estes estudantes não tinham convicção do que estavam dizendo. O estudante G15 afirma que as células somáticas não apresentam cromossomos sexuais.

G04 - "Célula germinativa ... é só eliminar quem é germinativa e somáticas são as que têm funções. Germinativas são os óvulos e os espermatozóides. ”

G11 - "Células somáticas são aquelas células prontas, as superficiais. As germinativas eu sei que faz parte da espermatogênese, da ovulogênese e as células somáticas não são essa parte."

G15 - "Lembro de reprodução, mitose, meiose, eucariótica. As somáticas não são sexuais. Tem todos os cromossomos homólogos e os outros cromossomos. As germinativas são os gametas. Determina se vai ser mulher, se vai ser homem. Tem tudo nela. As germinativas tem tudo, as somáticas não tem nem X e nem $Y . ”$

G17 - "Somáticas são as de todo o corpo e reprodutivas são as sexuais que se dividem por meiose gerando células com a metade dos cromossomos. Somáticas se dividem formando células-filha idênticas a ela."

Houve um número considerável de estudantes que respondeu à questão de maneira satisfatória, dentro de um contexto científico. Alguns responderam de maneira bastante objetiva, enquanto outros procuraram explicar abordando os 
conceitos de célula haplóide e diplóde e os processos de divisão celular, por exemplo.

G05 - "Células somáticas é do ... é ... são relativas ao corpo inteiro. As germinativas são os espermatozóides ou os óvulos. ”

G08 - "Célula somática é célula não sexual, diplóide. Célula germinativa é célula sexual, célula haplóide."

G12 - "Somáticas são as células que formam os tecidos, os órgãos e células germinativas são as que dão origem aos gametas. As somáticas são $2 n$, as germinativas são as ovogônias ou as espermatogônias. São 2 n que vão sofrer mitose até formar células $n$, espermatozóide ou óvulo."

G14 - "Somáticas são as diplóides que tem $2 n$ e as germinativas seriam as haplóides. Somáticas poderiam ser as da pele e as germinativas os gametas, por exemplo."

G16 - "Células somáticas são todas as do nosso corpo, exceto as germinativas que são as que vão dar origem aos gametas."

G19 - "Células somáticas são as células que contêm o número completo de cromossomos. Células germinativas são as que vão ser usadas para a reprodução, que vão fazer meiose e têm a metade do número de cromossomos."

G25 - "Células somáticas são as células constitutivas da gente, $2 n$ e as células germinativas é a célula sexual, acho que é n."

G27 - "Células somáticas são aquelas células que formam o indivíduo e as células germinativas são as células que estão lá nas gônadas e que servem para a 
reprodução. Tem a metade do número de cromossomos, sofrem meiose e vão se juntar e vão formar um embrião, um novo ser."

G29 - "Células germinativas têm só uma cópia do código genético e as somáticas têm duas cópias."

\section{II.12 _ Clonagem da ovelha Dolly}

Perguntamos aos estudantes o motivo pelo qual a clonagem da ovelha Dolly causou tanto impacto. Houve estudantes que afirmaram não saber, outros tentaram arriscar um palpite, porém as respostas foram inadequadas. Nesta questão esperávamos que os estudantes respondessem que a novidade foi a utilização de uma célula somática proveniente de indivíduo adulto. No entanto, vários estudantes não sabiam se a célula usada era somática ou germinativa. Alguns explicavam todo o processo, mas de maneira inadequada sob o ponto de vista científico.

G01 - “Acho que eles usaram células ger... ger... ger... como é mesmo o nome? Ah, não lembro..."

G31 - "Não sei, mas imagino que eles usaram uma célula somática para a Dolly. Não sei dizer."

G10 - "Eles pegaram uma célula somática do animal e introduziram em uma célula germinativa, fazendo com que a matriz não tenha sido ... de uma matriz só eles produziram um outro animal, então não teve essa coisa da mistura genética, o animal novo era basicamente o anterior. Eles pegaram o material, produziram o material genético da matriz, na verdade uma célula que tinha capacidade de divisão e a partir daí originaram um novo animal com as mesmas características do anterior, exatamente iguais, né, réplica."

G11 - "Foi conseguir formar um ser humano a partir de uma ... de outro ser. Pegar uma célula já pré-existente e conseguir formar um ser." 
G13 - "Eles pegavam uma célula e tiravam o núcleo e colocavam o núcleo da mãe da Dolly.”

Um único estudante, G15, levanta a questão da bioética, tema pouco trabalhado nos cursos de Ciências Biológicas.

G15 - "Lembro que teve muita polêmica se ela ia viver se ela ia crescer. Se aquilo era certo ou errado. Aí começaram a discutir sobre como era feito, era umas curiosidades que saía nas revistas. Eles usaram para fazer a Dolly uma célula sem núcleo de uma mãe que só ia portar ... que seria fecundada pela outra, que iria depois pôr um núcleo nessa primeira. Ai eles colocaram numa $3^{a}$ pessoa. Eles usaram células somáticas."

G17 - "Que ela já era velha logo que nasceu, tanto que ela morreu com uma idade que não é comum para uma ovelha. Pegaram o núcleo de uma célula colocaram dentro de um ovário. Usaram célula somática."

G18 - "Foi extraído o núcleo da célula de uma ovelha, foi usada célula germinativa. Foi extraído o núcleo da célula germinativa de uma ovelha e foi colocada em uma outra célula para ter a interação entre a célula completa e o núcleo que seria igual e ai estaria causando estas diferenças. É o que eu lembro. Eu acho que basicamente é a interação entre essa célula que teoricamente seria mais útil, ou seria melhor preparada para juntar núcleos de uma outra ovelha. A célula que recebeu o núcleo era germinativa também. Eles usavam duas células germinativas.”

G25 - "Não foi fecundação. Eles pegaram o genoma, os genes, o cromossomo de um ser já constituído, da ovelha mãe e transportaram direto para o ... foi um clone, foi igual aquilo, não teve fecundação nem nada. Foi uma célula somática que virou um novo indivíduo." 
G30 - "Pelo que eu me lembro ao invés de eles pegarem uma célula germinativa tirar o núcleo e colocar o núcleo de uma célula somática, eles pegaram uma célula somática para tirar o núcleo e adicionar o núcleo de outra célula somática e fazer essa célula voltar ao estágio que ela pode formar um embrião."

G33 - “A Dolly foi feita a partir da célula da glândula mamária de uma ovelha, se não me engano, e retiraram o núcleo do gameta feminino e colocaram esse núcleo ... do gameta não, mentira, do embriãozinho ... Juntou espermatozóide e óvulo e aí ... acho que viajei completamente. Tinha uma ovelha que tiraram uma célula e o núcleo dessa célula foi colocado no citoplasma do zigoto. Eles pegaram uma célula somática e a partir dela eles fizeram um organismo inteiro."

Encontramos estudantes que começavam respondendo corretamente à questão, mas no decorrer da entrevista se confundiam com os conceitos e o resultado era uma resposta incompleta ou confusa. Nas respostas abaixo relacionadas, temos em comum o fato de que, mesmo que alguns desconheçam as técnicas de clonagem, todos tinham conhecimento do uso de células somáticas no processo de clonagem da ovelha Dolly.

G04 - “A Dolly foi feita com célula somática. E ainda tem outra célula lá que agora eu não consigo lembrar ... Células-tronco ... acho que são essas ... elas sofrem induções também, né?"

G14 - "Eles pegavam uma célula ... não lembro direito ... eles colocavam o material genético em uma célula e se divide para formar o organismo todo. Eles usaram células somáticas."

G16 - "Lembro da imagem que passou muito na televisão daquela célula que foi enfiada uma glândula pra retirar o núcleo e colocar outro. Eu acho que foi usada célula somática para fazer a Dolly, não tenho certeza." 
G19 - "Eles pegaram um óvulo ... colocaram numa outra ovelha e colocaram na ovelha que seria barriga de aluguel e esse óvulo foi fertilizado com ... não, ele não foi fertilizado, eles pegaram o núcleo dessa ovelha que seria, de uma outra ovelha, pegaram o núcleo colocaram no óvulo. Esse núcleo foi tirado de uma célula somática."

G22 - "Utilizaram células somáticas ao invés de germinativas. Pegaram uma célula qualquer do organismo e implantaram um DNA já pronto. A gente está acostumado a ter a criação do organismo através de duas células germinativas, uma que vem do pai e uma que vem da mãe e aí forma um outro organismo com a fusão dessas duas células. No caso da Dolly não. Pegaram uma célula somática que tinha o DNA completo e introduziram nessa célula e estimularam o desenvolvimento. A gente sabe que todo DNA tem toda a informação. Qualquer DNA de qualquer célula tem toda a informação daquele organismo. Eles estimularam essa célula já pronta para se reproduzir r formar um novo organismo."

G24- "Eu acho que a Dolly deve ter sido diferente porque é um mamifero, é um animal grande não é pequeno e acho que a técnica é diferente e acho que basicamente por ser um animal grande. Eles usaram células germinativas e somáticas para fazer a Dolly. Eles retiraram o núcleo de uma célula da glândula mamária, não lembro direito, e colocaram em uma célula germinativa."

Houve estudantes que responderam de maneira adequada, dentro do esperado e alguns foram além do que esperávamos, com explicações bastante completas sobre o processo de clonagem.

G12 - "Foi retirado o material do núcleo ( $2 n$ ) de uma célula da glândula mamária de uma ovelha A. Pegaram um ovócito de uma ovelha $B$, retirado o núcleo e foi colocado esse material 2n. Só que todo ovócito tem substâncias que induzem à formação de tecidos, então esse material do núcleo e do ovócito 
dessas substâncias que induzem à formação de tecidos sofreu clivagem. Foi clivando, diferenciou, como se já fosse um óvulo fecundado para virar $2 n$ e foi formando um novo ser e esse ser foi transportado para uma ovelha $C$; mas a Dolly era geneticamente igual à ovelha A. De muitas tentativas que eles fizeram conseguiram só aquela lá. A maioria dos casos de clonagem desse tipo, o ovócito não fixa no endométrio. E este foi um caso que fixou, só que a ovelha tinha nascido com a idade de outra que doou o material nucléico."

G21 - "Não é possível formar os indivíduos a partir de células somáticas. Esse foi um grande feito. A partir de uma célula somática, acho que epitelial, não sei, foi retirado o núcleo, era já uma célula diferenciada, que já tinha muitos genes foi diferenciada e foi colocado dentro de um óvulo sem núcleo. Quer dizer o núcleo de uma célula somática que deu origem a um no individuo."

\section{Análise das Entrevistas - Parte B}

As entrevistas foram concluídas com duas questões que não abordavam conceitos de Biologia/ Genética. A primeira abordava a metodologia de aula que os estudantes tiveram durante sua formação e a segunda tratava da opinião desses estudantes sobre o uso de modelos e analogias. Ao abordarmos tais questões, nosso objetivo foi de tentar relacionar as concepções conceituais dos estudantes com a metodologia utilizada pelo professor do Ensino Superior no decorrer de suas aulas. Além disso, também buscamos saber a opinião dos estudantes sobre a importância do uso de modelos e analogias como instrumentos facilitadores do processo ensinoaprendizagem. Abaixo apresentamos as duas questões, um breve comentário sobre os resultados e alguns trechos das entrevistas que julgamos mais significativos para a discussão dos resultados.

$1^{a}$ questão: Perguntamos aos estudantes se nas aulas o conteúdo era abordado por meio de exemplos ou comparações. 
Todos os estudantes (100\%) afirmaram que na grande maioria das disciplinas o conteúdo era muito extenso e tratado de maneira descritiva, descontextualizado e desinteressante. Um número bastante reduzido (18\%) de estudantes apontou que em uma disciplina isolada o professor procurava fazer uma abordagem mais diferenciada, utilizando modelos e analogias para concretizar conceitos muito abstratos, mas que, via de regra, isso não era um fato cotidiano nas Instituições.

G01 - "Só o conteúdo, não tem abordagem histórica e nada diferente. É só a matéria tradicional. É tudo muito corrido."

G04 - "Os professores falam bem pouca coisa desse tipo. Eles falam pra que serve a coisa, mas não explicam como se origina, em que condições o pesquisador está descobrindo, nada disso.”

G05 - “É tudo jogado. Dá a matéria e já saí explicando. Não fazem comparações, nem alguma coisa diferente."

G07 - "Raramente os professores abordam aspectos históricos ou analogias. Não há discussão em torno do assunto. Eles apresentam como é o histórico, mas não chegam a debater mostrando como os pesquisadores chegaram a aquela conclusão. Falta muito isso."

G08 - "Temos uma deficiência nesse aspecto. Professores não trabalham com analogias, é a matéria e só. Na prova também não tem analogias. Os aspectos históricos também são deficitários aqui. Os professores não conseguem passar muito bem a matéria. Ele joga as coisas e a gente fica muito perdido. Pouquíssimas matérias são feitas essas abordagens diferentes. Acho que durante todo o curso as abordagens diferentes aconteceram só em duas matérias." 
G09 - “Analogia não há, quase nunca. Tem vezes que algum professor até tenta, mas fica só na tentativa. Em Biologia Celular a professora usava algumas comparações."

G10 - "Só trabalhavam de maneira tradicional, foram pouquíssimas aulas que a gente teve alguma coisa de modelos, que auxilia bastante o aprendizado. No colégio eu tive bastante e boa parte do meu conhecimento eu devo a isso."

G12 - "Citogenética é a melhor de todas, mas é a que o pessoal encontra mais dificuldade. Ela faz muito estudo dirigido. Ela dá um monte de coisas para a gente ler sobre o tema antes. Ela monta todas as aulas e quer que a gente pense em como os caras chegaram a tais conclusões, ela trabalha o histórico. Tem que ler antes e no dia da aula ela conversa sobre tudo aquilo lá. Se você leu antes e assiste a aula já entende, se não leu antes você bóia. Precisa dedicação. Ela quer que saia da gente como aquilo chegou a essa técnica, o que eles tiveram que fazer. Tem muito professor que dá aula normal, não compara com nada. Outros poucos fazem relações."

G16 - "Nunca, jamais aconteceu. Toda relação que eu fiz de assuntos, de uma coisa com a outra, foi porque eu namorei quatro anos com uma pessoa que eu conheci aqui na faculdade e que trabalha com Biologia Molecular e já estava bem mais adiantado do que eu, e eram coisas que ele aprendia no estágio dele, no trabalho dele, que começou a fazer pós-graduação, e o resto era coisa que eu ficava intrigada, não conseguia entender e eu ficava pensando, pensando horas em casa, vendo qual que era a relação. Por que eu tenho muita dificuldade para estudar, eu não consigo estudar tudo separado da forma que eles ensinam, então eu tenho até notas baixas e tal, por causa disso, porque eu não consigo estudar da forma que me é ensinado aqui, as coisas em blocos estanques. Isso é isso, porque é isso e pronto. Não! Eu misturo ecologia com botânica, com evolução, misturo botânica com genética, não consigo ver as coisas separadas. Não dá pra separar, porque botânica é Genética também, só que a gente só aprende genética humana; 
acho que se a gente sair perguntando para os biólogos daqui se planta tem DNA tem gente que vai ficar em dúvida."

G17 - "Que eu me lembre não. Tanto que quando eu vi a historinha do João que você trouxe, eu fiquei perdida. Eu até entendi, só que para eu traduzir ela pra você foi dificil, porque não estou acostumada. Porque os professores falam assim: "Oh, isso faz isso, depois transforma nisso”, e não quer saber o que você pode usar para lembrar, fazer relações. Na minha cabeça, essa história de RNA mensageiro, transportador, sempre foi uma incógnita eu acho que na verdade eu ainda nem entendi, eu acho que eu decorava aquilo na hora da prova e depois nunca ficou muito na minha cabeça."

G19 - "Genética é horrível, passa o conteúdo e só. Você decora o que os homens fizeram na história e só. Tal pessoa, tal pesquisador fez essa experiência. Aí você vai lá ler e na prova ele te pede exatamente o que passou na lousa. $O$ que esse pesquisador fez, aí você vai lá e escreve tudo aquilo na prova. Você entende muito por cima e vê que não é uma coisa assim tão fácil. Você vai lendo e percebe que demorou muito para eles chegarem a alguma coisa. A gente não é instigado a investigar, só a decorar."

G20 - “É muito dificil. São poucas as matérias. Na minha opinião, que eu me lembre que a gente tenha construido modelos, não é muito trabalhado, fica mais por conta das aulas teóricas e práticas mesmo. Tem um experimento e só. $\mathrm{Na}$ minha opinião não é muito trabalhado, acho que é muito tradicional. Tradicional no seguinte sentido é a teórica, a exposição de um monte de conteúdos. Eu acho que existem matérias que isso é mais difícil de ser trabalhado de uma maneira alternativa. Lógico que deve dar, mas eu acho que talvez seja um pouco mais difícil. Zoologia tem conteúdos muito densos, com um monte de características, um monte de nomes e é um pouco mais dificil de trabalhar alternativamente. Agora tem professores que mesmo que não seja o curso todo ou com vários assuntos, com um assunto ou outro acaba tentando trabalhar dessa maneira. Tentando adotar uma metodologia 
diferente para ensinar, ou em microbiologia, ou o próprio professor "Tal" tem uma aula diferente."

G21 - "Depende da matéria. Em Genética, Biologia Molecular e Biologia Celular, sim, existiam modelos, os professores eram mais didáticos, principalmente em Genética, eles sabiam como falar, quando usar uma analogia para esclarecer. Agora as outras matérias não. A grande maioria era apenas o conteúdo pelo conteúdo, o máximo que eles usavam era o datashow e algumas figuras, mas isso não esclarecia muito. O que a gente fazia era procurarmos entender por nós mesmos, conversar com os amigos. Tudo dependia do desespero. Se a prova fosse na semana que vem, a gente pegava o caderno de alguém que copiava tudo o que o professor falava, colocava aquilo na cabeça como dava. Chega na hora da prova você despeja tudo aquilo com dá. Aí não sobra muito. Você despejou tudo e não ficou nada. Mas isso eu sei que é errado."

G22 - "Com raras exceções de alguns professores que tinham alguma preocupação com o ensino e investiram nas aprendizagem do estudante, com raras exceções que teve na faculdade ao longo de todo o meu curso, as aulas foram extremamente tradicionais. Foi muito menos do que aula e experimento, muito pior do que isso. Só aula expositiva, aula teórica. Existia uma falta de percepção pedagógica dos professores. O intuito deles era que os estudantes decorassem e não que aprendessem. Na verdade acho até que eles gostariam que aprendesse, mas a metodologia que eles usavam não... metodologia de armazenamento da informação e não de conhecimento da informação."

G24 - "Particularmente em Genética foi uma das matérias bem diferentes, porque como você sabe, o professor "Tal" sempre procurou aplicar de uma maneira diferente, ele tem essa preocupação, então eles usaram coisas bem diferentes. Agora tem muita matéria aqui na Universidade que parece um esquema de... na verdade não de escola, mas o cara vai lá dar a aula fica passando slide, passando slide, te dá o livro você vai lá e estuda, mas logo esquece. Então 
muitos professores acho que a maioria, não se preocupa em tentar mudar a maneira como se dá a matéria e eu tenho muitas coisas que eu não me lembro porque acho que muitos professores não se preocupam com essa parte de tentar passar de uma maneira menos maçante."

G28 - "A maioria das aulas é aula expositiva e as práticas é apenas cumprimento de protocolo, embora quando você entra aqui você seja levado a pensar sobre um formato de estudo diferente, a maioria das matérias é tratado como se fosse um colegial, onde você tem aquele conteúdo fechado, restrito, que você teoricamente aprende, mas é na verdade decorar e você tem as práticas ligadas ao assunto que também não são tão interessantes assim. Pode ser interessante para eles como especialistas. Mas tem algumas matérias que fogem um pouco disso, por exemplo, metabolismo e fisiologia vegetal eu sou monitora também, a gente busca fazer com que o estudante se interesse por um projeto, eles pensam em como deveria ser ensinado aquilo, o que eles querem trazer para o projeto deles, Biologia Molecular também, a gente montava muitos modelos, conversava, tinha as aulas de discussão que era feita em grupo, então você trocava muita informação entre os estudantes mesmo. Cada um estudava uma parte e ensinava para os outros. Acho que microbiologia também tinha um conceito diferente de ensino, que era estudo dirigido, mas a maioria das matérias aqui é assim, bem tradicional. Eles passam um conteúdo aí você vai para a aula prática para exemplificar o que eles falaram na teórica, mas é uma coisa bem fechada, é só para provar que o que eles falaram é verdade."

G30 - "Depende muito do professor e da disciplina. Tem professor que é super tradicional e acho que a primeira transparência que ele usou na primeira turma que ele deu aula acho que ele usa a mesma até hoje, o slide está até meio amarelo, meio mofado, porque são as mesmas coisas e se você assiste uma aula dele hoje ou daqui a um ano vai ser igual, a mesma aula, independe dos estudantes, independe do que está acontecendo no mundo. Tem professores que usam modelos, filmes, outros recursos para explicar o 
conteúdo e então tem de tudo. Geralmente o pessoal que traz modelos é um pessoal que está restrito a alguns departamentos específicos."

G32 - "No geral eram aulas tradicionais, eram aulas expositivas, aquele classicão, né, e assim, coisas de Biologia Molecular as aulas práticas eram simplesmente cumprir protocolo, você nem sabia o que estava fazendo, nem sabia o porque estava fazendo aquilo. A gente fazia porque tinha que fazer, nem a ciência havia descoberto ainda, mas a gente simplesmente recebia protocolo e seguia, acho que ficou mais no tradicional mesmo. Que eu me lembro vagamente de aulas que não tenham sido tão tradicionais foi mais do comecinho do curso que nem era tão tradicional, foi em Genética, a gente tinha textos para ler, tinha que discutir sobre temas atuais tinha que fazer modelos, por exemplo, de meiose, então eu lembro que de Genética foi uma coisa que diferenciou um pouco, agora as outras disciplinas eu acho que foi meio quadradão assim, acho que limitante até."

G33 - "Acho que a grande maioria foi bem tradicional, bem. as vezes acho que, teve uma época que eu comecei a desencanar de vim em aula, porque a minha aula são os meus livros. Pegar a bibliografia para estudar para uma prova, porque realmente estudava na hora da prova, pegava lia e falava, bom o professor fez um resumo, até as figuras que o professor tinha usado estavam no livro .Mas depois eu comecei a perceber que era interessante ir para aula porque era uma síntese de toda a bibliografia que eles passavam então fixava mais o conteúdo, mas só por isso, porque as práticas não passavam de cumprimento de protocolos. Parece que aquelas aulas estão montadas há MUUUUUUUUIIITTO tempo e parece que não tem uma revisão no conteúdo que é passado, só tem acréscimo na verdade. Ah saiu um paper de não sei o que,o professor lê e joga. Mas acho que teve só umas cinco ou seis matérias em que as pessoas se empenharam realmente com outros instrumentos pedagógicos. É bem expositivo mesmo, tradicional."

$2^{\text {a }}$ questão: Perguntamos aos estudantes se eles acham que o uso de modelos e analogias facilitam o aprendizado. 
Todos os estudantes entrevistados (100\%) afirmaram que seria muito importante se os professores passassem a fazer uso mais freqüente de modelos e analogias para explicar conteúdos abstratos. Alguns destacaram o risco da simplificação do conceito com o uso do modelo ou da analogia e pontuaram que a validade existe, desde que respeitadas as limitações do recurso. A fala do estudante G05 foi bastante interessante, pois ela não sabe se os modelos e analogias podem facilitar o aprendizado, mais destaca que do jeito que as aulas são dadas não se aprende. Um dos entrevistados destaca o risco de, durante uma aula com modelos, os estudantes dispersarem e começarem a brincar com o material e acabarem se esquecendo do conceito que está sendo trabalhado.

G02- "Acho que sim, porque a matéria é muito difícil e se a gente relacionar com alguma coisa conhecida pode ficar mais fácil."

G05 - "Não sei te dizer se fica mais fácil, pode ser que sim. Mas sei que do jeito que é dado não dá para aprender."

G08 - "Acho que sim. Ajudaria até na hora de fazer o provão. Exigem que você responda questões de uma maneira que a gente não aprendeu. Isso é muito ruim."

G12 - "É muito melhor. Você vê o comprometimento da professora, por exemplo, a de Citogenética e a gente reconhece e se esforça. Ela dá o exemplo da dedicação. Quando você não é comprometido e dá aula por obrigação, você não faz nada diferente e não desperta interesse."

G14 - "Comparando com o dia-a-dia é mais fácil, você se interessa mais."

G16 - "Eu acho que sim, mas eu também acho que seria muito bom se fosse estipulado um objetivo e você tivesse que correr atrás do seu objetivo achando as formas, se fosse orientado de como chegar lá, por que daí quando você aprende... porque eu aprendi muita coisa sozinha, eu estudei em 
uma escola muito ruim, estudei na escola pública noturna, não tive Biologia no terceiro ano, só tive ecologia no primeiro e um pouquinho de evolução e genética no segundo. Eu fui meio que autodidata, porque meu objetivo é ser bióloga, então eu acho que quando você tem um objetivo e é dado pistas e orientado você consegue chegar lá."

G17 - "Acho que sim, porque acho que deixaria de ser uma coisa tão irreal, para mim DNA não é uma coisa real, como você sabe que existe? Quem garante? Eu não estou vendo. Nunca ninguém me mostrou. É diferente do que quando você olha uma célula. Você vê a célula, está vendo que existe. Você pega um corte histológico e vê que é formado por células, então você pode extrapolar e concluir que seu corpo é formado por células. Mas o DNA eu nunca vi, quem me garante que ele existe e que ele é uma dupla-hélice? Eu se não quiser acreditar? São coisas que eu não consigo acreditar. Aí eu penso, se eles estão falando eu tenho que acreditar porque eles sabem o que falam."

G18 - "Ajuda muito, principalmente Genética. Genética é uma matéria meio abstrata. Tipo Aa, o que é A e a? Apesar de adorar genética e querer seguir essa área eu pensava o que seria $A$ e a? Acho que você fazendo uma comparação com coisas mais concretas, facilita o trabalho deles e facilita o jovem também, porque é uma coisa prática que ele vai estar usando."

G21 - "Facilita, mas você precisa pensar bem na analogia, porque senão ela pode confundir a cabeça do cara. Já pensou se eu usar o metrô às seis da tarde para explicar a difusão, eu acho que funciona. Dá para visualizar."

G22 - "Com certeza. Se eles utilizassem outros recursos, como estímulo àquilo que nós estamos aprendendo, seja uma aula de laboratório, seja uma aula de discussão, seja uma aula de levantamento de perguntas, um questionamento, com certeza a informação seria muito mais... seria muito mais fácil. Mais prazeroso de se estudar e ia ser muito mais fácil de guardar como 
conhecimento e não apenas como conteúdo ou armazenamento de informações."

G24 - "Eu acho que sim. Eu não sei como se faz, a gente não tem uma receita para isso. Não sei se tem uma maneira de fazer com que o estudante goste da matéria e se interesse por aquilo, mas não sei se existe uma receita para isso, para você dizer: "Olha pra você gostar disso faz assim, tá.". Mas eu acho que eles podiam, porque não vou falar todos os professores, mas eu sinto que alguns vão dar aula porque tem que dar. Porque eles estão em uma Universidade pública e são pesquisadores e para ficar aqui eles precisam dar aula. Então, alguns eu acho que tem essa postura, vai dar aula porque tem que dar. Agora tem outros que se preocupam mesmo, como o professor "TAL” e nem sei mais quais professores. Alguns se preocupam com isso, agora outros parece que vão dar aulas só por dar mesmo, se tivesse uma preocupação a gente sairia com uma formação um pouco melhor. Na faculdade as coisas dependem muito mais do estudante. A gente tem que ir atrás tem que ir à biblioteca, mas acho que o professor poderia dar um incentivo."

G26 - "Acho que sim. Tipo uns negócios de bioquímica que você tem que ter fé para acreditas. Acho que ajuda bastante."

G27 - "Por estar acostumada com aula teórica tradicional, no início eu tinha sentido uma certa resistência nessas aulas que a gente tinha que fazer exercícios, de propor atividades. A gente está muito acostumado com as aulas tradicionais. Acho que essas aulas de modelos e analogias ajudam bastante principalmente em Genética e Biologia Molecular que é muito complicado para você entender. É muito pequeno, não é visível.Você tem que imaginar, e às vezes é difícil você imaginar pela primeira vez as coisas acontecendo dentro de uma célula. Então acho que os modelos tridimensionais ajudam a gente a entender, a visualizar. Mas você precisa ter uma abstração para ver aquilo se mexendo, funcionando." 
G28 - "Eu acho importante, mas acho que o grande preconceito em usar modelos e comparações é você simplificar o problema, porque muitas vezes você recorre a um modelo para explicar uma coisa, não que deturpe, mas você simplifica a coisa, você torna ela menor. E na verdade não é isso que deveria ser esperado, você deveria compreender a coisa na complexidade que ela tem, mas sem simplificar, e às vezes, os modelos quando mal empregados eles podem levar ao erro, talvez essa seja a ressalva pela qual muitos professores não gostam desse tipo de metodologia de trabalho."

G30 - "Acho que facilita, mas eu acho que às vezes o que acontecia é que tinha essas aulas com modelos, por exemplo, de massinha para explicar as coisas, também se criava uma enorme dispersão na sala, a gente acabava brincando com a massinha, fazia bichinho com a massinha e o conteúdo que estava ali acabava meio que se perdendo, então eu acho importante, mas tem que tomar cuidado como que se encaminha essa atividade diferente."

G31 - "Com certeza ficaria mais fácil. As matérias mais abstratas até utilizaram bem os modelos, que seria Genética e Biologia Molecular, por exemplo, que não tem outro jeito se você não apresentar um modelo, fica meio inviável."

G32 - "Acho que ajuda. Para alguns assuntos sim, em outros assuntos a analogia acaba caindo em uma coisa meio grotesca, acaba caindo meio no errado. Mas tem muitas coisas, principalmente essa parte de Biologia Molecular que é muito micro, isso no Ensino Superior e no Ensino Médio também, eu acho que é super importante procurar fazer modelos, analogias, tipo esse texto aqui que a gente lê uma historinha assim, acho super importante."

G33 - "Acho que ajuda sim, porque eu acabei de lembrar de um exemplo de uma prática do Ensino Médio que muita gente não teve no Ensino Médio. Tem alguns professores daqui que desenvolvem coisas para o Ensino Médio e usam com a gente e funciona muito bem, o professor "TAL” fez esse negócio de código genético com a gente para explicar com miçanga que foi muito 
legal. Teve a aula de vasculares que foi super interessante que elas pegaram caixinhas de plástico para mostrar células para a gente ter uma idéia tridimensional da coisa. E olha que a gente fazia corte, a gente tinha acesso a um monte de coisas diferentes, a gente fazia desenho, eu tinha um caderno de desenho de vasculares que eu fazia desenho, pintava, tudo bonitinho e mesmo assim você fica você fica com um monte de dúvida. Então o professor chegava e mostrava uma caixa com umas fitas e tal, aquilo facilitava muito a compreensão.E trabalhar mesmo com material, às vezes é esquisito porque a gente vê em slides, vê em Power Point e você não consegue ver de verdade. É a mesma questão da aula, quando o professor leva uma coisa pra você ver de verdade fica mais fácil porque você acaba gravando muito melhor as coisas, entendendo, porque na verdade o que a gente faz é uma descrição de tudo o que é vivo, então fica muito mais fácil através da observação do material ou dos modelos, eu acho super válido." 


\section{Discussão}

Galagovsky e Adúriz-Bravo (2001) afirmam que o ensino de Ciências pode ocorrer de diversas maneiras e destaca três linhas básicas:

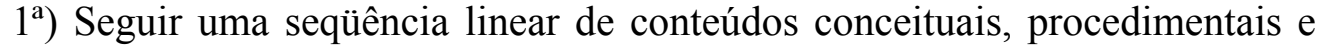
atitudinais, começando com um número reduzido de temas que iriam sendo ampliados em quantidade à medida que a escolarização avança. Essa linha sugere que os conceitos científicos sejam trabalhados proporcionalmente aos anos de escolaridade do estudante, supondo que o formando do Ensino Superior tenha o conhecimento máximo de conceitos dentro de sua área.

$2^{\text {a) }}$ Uma visão totalizadora de conteúdos conceituais, procedimentais e atitudinais, de tal maneira que sejam abordados grande volume de informações desde os primeiros anos de escolarização, variando os níveis de aprofundamento conceitual à medida que a escolarização avança. Essa linha defende a idéia de que cada estudante chega na escola trazendo consigo algum tipo de conhecimento a respeito dos saberes científicos e que o domínio mais aprofundado destes conceitos deva ser proporcional aos anos de escolaridade, supondo que o formando do Ensino Superior tenha conhecimento com a máxima profundidade conceitual.

$3^{\text {a }) ~ U m a ~ c i e ̂ n c i a ~ e s c o l a r ~ q u e ~ e n v o l v e r i a ~ u m a ~ v i s a ̃ o ~ s e l e t i v a ~ d e ~ c o n t e u ́ d o s ~}$ conceituais, procedimentais e atitudinais, de tal maneira que a seleção de conteúdos consistiria na relevância dos conceitos estruturantes das disciplinas científicas, adaptados à realidade de cada região. Essa linha espera que cada estudante, ao final da educação obrigatória, apresente um grau aceitável de alfabetização científica. Supõe-se que em um curso superior de uma área científica, os formandos adquiriram grande quantidade de conhecimentos específicos a fim de torná-lo um profissional da área, mas que não seriam parte imprescindível da bagagem cultural de um membro qualquer da sociedade.

De acordo com essas idéias, independentemente da maneira como a ciência é trabalhada nos diversos níveis de escolarização, o que se espera é que o formando do Ensino Superior, após muitos anos de estudo, tenha adquirido conhecimento máximo em sua área de atuação. 
Os estudantes que participaram deste trabalho de pesquisa são graduandos de último ano dos cursos de Ciências Biológicas. Assim, eles já passaram por, no mínimo, quatro anos de Ensino Superior e três anos de Ensino Médio, tendo estudado, nesse período, os conceitos básicos de Biologia. Devemos lembrar também que muitos freqüentaram cursinhos pré-vestibular, onde também tiveram a oportunidade de estudar Biologia. Em seguida, passaram por um curso superior de Ciências Biológicas e estão em fase de conclusão deste curso. Alguns dos entrevistados já estão atuando na área docente. Cabe ressaltar que o estudante G22 já havia concluído a graduação há alguns anos, concluiu o mestrado e agora voltou à Universidade para cursar Licenciatura e já está ingressando no doutorado. Em nossa pesquisa, buscamos investigar se os graduandos haviam se apropriado de alguns conceitos considerados básicos para o exercício profissional, de acordo com os Parâmetros Curriculares Nacionais para o Ensino Superior. Nossos resultados mostram que, apesar dos anos de estudo de Biologia, a maioria dos estudantes entrevistados apresentam muita deficiência em conceitos básicos de Genética, Biologia Molecular e Biologia Celular. É interessante destacar que, pouco mais de $33 \%$ dos estudantes entrevistados apresentam sérias dificuldades conceituais, não apresentando o conhecimento mínimo necessário ao exercício profissional. Durante as entrevistas, esses estudantes deram explicações confusas, superficiais, distorcidas ou lançaram mão do senso comum para se referir aos conceitos investigados. São freqüentes as respostas com palavras soltas e desconexas ou ainda utilizado o significado etimológico da palavra como definição dos conceitos. Acreditamos que esse resultado seja conseqüência de uma aprendizagem mecânica, por memorização que, geralmente, se dá através de conceitos estanques, sem uma visão totalizadora da Biologia, em que os conteúdos conceituais não abordam os procedimentais e os atitudinais.

Pouco mais de 51\% dos estudantes apresentam alguma dificuldade em relação aos conceitos tidos como cientificamente corretos. Há conceitos que foram compreendidos e incorporados por esses estudantes, porém outros são totalmente desconhecidos ou constituem equívocos sob o ponto de vista científico. As respostas desses estudantes, em muitas ocasiões, são recheadas de insegurança, a ponto de o estudante responder à questão de uma maneira aceitável e no final da resposta negar 
o conceito tido inicialmente como correto. Apenas pouco mais de $15 \%$ dos entrevistados responderam as questões com embasamento teórico, utilizando respostas completas e pautadas em conhecimentos cientificamente válidos. Além disso, esses estudantes são capazes de estabelecer relações adequadas entre os diversos conceitos biológicos.

Em relação ao conceito de mutação, os resultados evidenciam que, apesar de o livro didático abordar o conceito de mutação com uma conotação positiva e discutir os diversos fatores que levam à variabilidade genética, ainda é muito forte a concepção de mutação como sendo uma alteração genética que traz prejuízos ao organismo, podendo ocasionar doenças genéticas ou, em muitos casos, a morte do indivíduo.

Condit e colaboradores (2002) alertam que se deve ter cautela ao utilizar o termo mutação quando este é usado para a comunicação com o público em geral, pois a conotação negativa do termo mutação é forte no discurso popular, fato que não se observa quando esse termo é usado pela comunidade científica.

Dos estudantes entrevistados, pouco mais de $24 \%$ destacaram apenas a conotação negativa de mutação, ou seja, apesar de serem formandos em Biologia, fazem uso de conotação semelhante ao público leigo. Pouco mais de $18 \%$ dos estudantes relacionam mutação à adaptação e pouco mais de $9 \%$ associam mutação à variabilidade, especiação e seleção natural.

Com relação ao conceito de variabilidade genética, encontramos estudantes que tiveram dificuldade para responder, pois conheciam os termos isolados, mas desconheciam o conceito.

Outros estudantes, no entanto, além de conhecerem o conceito foram capazes de estabelecer relações válidas entre variabilidade genética e conceitos afins, como mutação, adaptação, seleção natural, evolução e especiação. Alguns comentam a respeito dos fatores que levam à especiação.

Percebemos que pouco mais de $21 \%$ dos estudantes entrevistados não relacionam mutação a outros conceitos. Na nossa opinião, isso ocorre pelo fato de os estudantes aprenderem de maneira mecânica e sem que percebam a ligações conceituais. A maneira como os conteúdos são abordados pelas diversas disciplinas também não favorece essa interligação conceitual. Na maioria das vezes o estudante 
não percebe que a divisão do conteúdo em disciplinas é apenas uma maneira de organizar o currículo e acaba tendo uma visão fragmentada da Biologia, acreditando que seja composta por uma série de conceitos isolados e que não se relacionam entre si.

Em relação ao conceito de genótipo fundador, não encontramos nos livros didáticos consultados (Griffths, e col. 2001 e Campbell, e col. 1999) abordagem específica do assunto, há uma pequena citação em meio a um texto mais abrangente sobre variabilidade genética. Um fato que nos chamou a atenção foi $o$ desconhecimento do conceito de genótipo fundador declarado por mais de $72 \%$ dos estudantes que afirmaram nunca terem ouvido falar. Houve aqueles que tentaram responder por meio da definição etimológica das palavras isoladas. Apenas um estudante dos 33 entrevistados soube responder a questão. Esse estudante afirmou que só conheceu o termo "genótipo fundador" e compreendeu seu conceito durante o estágio em um laboratório de Biologia Evolutiva.

Os três conceitos previamente discutidos (mutação, variabilidade genética e genótipo fundador) estão intimamente relacionados e notamos que, geralmente, o estudante apresenta dificuldade nos três ou conhece todos eles. Ficou evidente que o conceito de genótipo fundador não é trabalhado nos cursos de graduação que os estudantes entrevistados cursaram. O conceito de mutação apresenta forte conotação negativa, enquanto o de variabilidade genética é visto como sendo um evento útil e importante para os seres vivos em geral, mas a relação entre os dois conceitos não é clara para a maioria dos estudantes.

Quando procuramos investigar as concepções dos estudantes sobre DNA e sua localização, não encontramos nenhum que afirmasse nunca ter ouvido falar da sigla e todos responderam à questão. Atribuímos o fato de nenhum estudante alegar desconhecimento do assunto à abordagem constante do termo DNA pelos meios de comunicação. Atualmente, qualquer cidadão que tenha acesso a rádio, televisão, jornais ou revistas já ouviu falar em DNA. No entanto, pouco mais de 39\% de estudantes crêem que o DNA é restrito ao núcleo celular, o que significa desconhecimento do DNA mitocondrial.

Encontramos estudantes que apresentavam uma concepção ingênua, utilizando-se do conhecimento do senso comum ou da aprendizagem por 
memorização para conceituar DNA. Outros, no entanto, além de conceituar, relacionam o DNA com a síntese de proteínas e com cromossomos, reconhecem os nucleotídeos como elementos básicos para a formação do DNA, além de conhecer a constituição dos nucleotídeos.

A aprendizagem por memorização fica evidente em alguns casos. Para exemplificar, podemos citar o estudante que afirma que o DNA fica dentro da célula de um vírus.

A relação entre DNA, aminoácidos, polipeptídios e proteínas também foi investigada. Encontramos apenas um estudante que declarou desconhecimento do assunto, porém as confusões conceituais apareceram em diversas respostas. Provavelmente isso acontece pelo fato de que a informação foi recebida passivamente pelo estudante e não passou a fazer parte de sua rede conceitual. Para que o conhecimento passe a fazer parte efetivamente da rede conceitual do aprendiz, é necessário que o estudante seja um sujeito ativo de sua aprendizagem, isto é, ele deve ser um agente na construção do seu conhecimento e não apenas receber as informações transmitidas pelo professor durante as aulas. O novo conceito deverá ser incorporado na rede conceitual do estudante e para que isso ocorra torna-se fundamental que ele encontre significado nesse conceito. Através da aprendizagem significativa é que temos o aprendizado efetivo (Ausubel e col., 1980).

Um fato bastante curioso que percebemos no decorrer das entrevistas foi o incômodo apresentado por alguns estudantes ao sentirem dificuldades em responder às questões. Eles acreditavam que sabiam os conceitos e quando percebiam que não tinham domínio de tais conceitos demonstravam insegurança, nervosismo e constrangimento. Houve estudantes que verbalizaram a decepção em descobrir o desconhecimento dos conceitos e chegaram a desculpar-se.

Quando são abordadas as relações entre RNA mensageiro, aminoácidos e polipeptídios, os resultados são muito semelhantes aos obtidos nos conceitos anteriores. Alguns alunos são capazes de estabelecer relações válidas entre os conceitos, no entanto os processos de tradução e transcrição ficam caracterizados como pontos de grande fragilidade no conhecimento desses alunos.

Um dos entrevistados destaca a importância do uso de modelos quando se trabalha com conceitos abstratos. 
Em sua resposta, esse estudante deixa evidente que o que ele lembra é proveniente do Ensino Médio, ocasião em que foi feito um trabalho com modelos. Ele inicia a resposta resgatando a lembrança do modelo e em seguida busca em sua rede conceitual a relação adequada aos conceitos solicitados.

Evidências demonstram que o uso de modelos pode proporcionar um caminho que possibilita a compreensão da natureza da ciência (Coll, 2005).

O autor considera que os modelos são uma ferramenta essencial da ciência e conseqüentemente da educação científica como uma tentativa de tornar acessível o conhecimento científico e para proporcionar uma compreensão mais clara de um determinado conceito. Pesquisas indicam que modelos e analogias são amplamente utilizados como ferramentas metacognitivas em ensino de ciências (Duit, 1991; Franco e col, 1999; Greca e Moreira, 2000).

Com relação ao conceito de retrovírus, nos livros didáticos consultados encontramos que são "vírus de RNA que é copiado em DNA pela transcriptase reversa". No ENC-BIO/2002, mais de 42\% dos estudantes acertaram a questão, enquanto mais de $23 \%$ afirmaram que o DNA viral é transcrito em RNA. Esse é o mecanismo normal de transcrição que ocorre em todos os seres vivos com exceção dos retrovírus. A resposta dos mais de $23 \%$ que fazem tal afirmativa evidencia que esses estudantes desconhecem os mecanismos de infecção de um retrovírus.

Quando abordamos o conceito de retrovírus nas entrevistas, o resultado nos chamou a atenção, pois pouco mais de $30 \%$ dos entrevistados afirmaram desconhecerem o que seja um retrovírus. Trata-se de um fato bastante preocupante, já que estamos nos referindo a estudantes formandos de Biologia.

Há estudantes que não sabem responder e dizem lembrar apenas de algumas palavras, mas como se trata de palavras soltas não conseguem elaborar uma resposta. Outros afirmam que trata-se de "alguma coisa que tem a ver com vírus", mas não sabe qual a diferença entre um vírus e um retrovírus.

Apesar de inúmeras respostas cientificamente inadequadas, encontramos estudantes que explicavam de maneira adequada o conceito de retrovírus, inclusive citando a enzima transcriptase reversa e seu mecanismo de ação.

Os conceitos de DNA e sua localização, a relação entre DNA e aminoácidos, $\mathrm{RNA}_{\mathrm{m}}$, aminoácidos e proteínas, aminoácidos e polipeptídios, processos de 
transcrição e tradução estão todos intimamente relacionados. No entanto, a impressão que tivemos no decorrer das entrevistas é que há estudantes que não percebem a interligação dos conceitos.

Os conceitos de transcrição e tradução foram abordados através de uma analogia. Como já foi mencionado anteriormente, acreditamos que o fato de muitos estudantes terem encontrado dificuldades em relacionar conceitos à analogia pode ser conseqüência de uma aprendizagem mecânica, por meio da qual o estudante decora conceitos e definições para a realização das avaliações e logo em seguida esse conhecimento é descartado. Para que o estudante obtenha êxito em questões que abordam analogias é preciso que haja aprendizado significativo. Assim, o novo conceito passa a fazer parte da rede conceitual desse estudante, sendo integrado a um todo muito mais amplo do que um simples conceito isolado. Quando o aprendizado ocorre de maneira significativa o estudante é capaz de resgatar a informação em sua rede conceitual e aplicar na resolução da situação-problema posta, no caso a analogia.

Em relação aos conceitos de células somáticas e germinativas, encontramos alunos que tiveram dificuldades em responder, enquanto outros respondiam de maneira satisfatória. Um dos estudantes entrevistados afirma que apenas as células germinativas possuem cromossomos sexuais e, portanto, as células somáticas não os contêm. A resposta desse estudante está de acordo com os resultados obtidos em pesquisas semelhantes realizadas na Inglaterra e na Espanha. Banet e Ayuso (2000) verificaram que estudantes espanhóis associam com grande freqüência a ocorrência de cromossomos e genes com gametas. Lewis e col. (2000) perguntaram aos estudantes do Reino Unido onde os genes são encontrados no corpo de um ser humano e cerca de $25 \%$ das respostas dos 368 estudantes que responderam à questão indicou que os genes se localizam apenas em células ou tecidos específicos, por exemplo, o sistema reprodutor masculino. Outra particularidade que notamos na resposta do estudante acima citado, foi o fato de afirmar que "células somáticas possuem cromossomos homólogos e outros cromossomos", ou seja, para ele, nem todos os cromossomos presentes em células somáticas são homólogos. 
Apesar de termos encontrado estudantes respondendo essa questão com conceitos completamente inadequados, mais de $72 \%$ dos entrevistados responderam de maneira satisfatória, dentro de um contexto científico.

Com relação à clonagem da ovelha Dolly os livros didáticos consultados apenas citam o fato, mas não há uma abordagem didática do assunto. Porém, há uma infinidade de trabalhos e livros paradidáticos que abordam tanto a técnica quanto as questões éticas que envolvem o tema.

Em nossas entrevistas, esperávamos que os estudantes abordassem as questões éticas e sociais a respeito do assunto. A grande maioria, praticamente 97\%, preocupou-se em descrever toda a técnica da clonagem reprodutiva sem, no entanto, mencionar os aspectos éticos e sociais que envolvem o tema. Apenas um aluno, dos 33 entrevistados mencionou as questões éticas, o que nos leva a crer que, provavelmente a bioética não está sendo trabalhada nos cursos superiores de Ciências Biológicas.

Para Amabis (1988), a presença sistemática de termos biológicos nos meios de comunicação reflete o interesse que o avanço da Biologia moderna vêm despertando em diversos setores da sociedade em nossas escolas, no entanto, para o autor esses progressos têm tido pouco ou nenhum impacto na escola. Nossos currículos necessitam, portanto, ser rapidamente modernizados no sentido de contribuir realisticamente para a formação de cidadãos críticos e participantes, capazes de assimilar as novas informações e interferir conscientemente na construção de uma sociedade moderna (Amabis,1988).

Para o autor, a desvinculação de nosso ensino da realidade político-social do país, não apenas no Ensino Médio mas também no Ensino Superior, torna-se evidente quando analisamos os currículos e a forma como as disciplinas são encaradas e ensinadas nas salas de aula.

No ENC-BIO/2002, os conceitos de retículo endoplasmático e complexo de Golgi são abordados por meio de analogias. Dos 12.376 estudantes que realizaram o exame, mais de $34 \%$ escolheram a alternativa considerada correta. No entanto, a mesma porcentagem de alunos (34\%) atribuem a função de acabamento especial de substâncias ao retículo endoplasmático rugoso. 
Ao consultarmos os livros didáticos, encontramos diversas funções atribuídas ao complexo de Golgi, porém a função de acabamento ou modificação de substâncias recebidas do retículo endoplasmático aparece, geralmente, no final do texto, após a citação e explicação de diversas outras funções atribuídas ao complexo de Golgi.

$\mathrm{O}$ resultado do ENC-BIO/2002 nos leva a pensar que por essa função ser abordada no final do texto, após várias outras, os estudantes não dão a devida importância, ou talvez pelo fato de os estudantes tentarem memorizar algumas funções, acabam fazendo isso com as primeiras que aparecem no texto e deixando para trás a função em questão.

Em nossas entrevistas encontramos uma parcela consideravelmente elevada (mais de 45\%) de estudantes que desconheciam as funções de ambos. Houve estudantes que tentaram, de alguma maneira, explicar os conceitos. No entanto, faziam uso freqüente de conhecimentos do senso comum ou respondiam de maneira incoerente e inconsistente através de palavras soltas e sem sentido.

O resultado da pergunta feita no ENC-BIO/2002 sobre esse mesmo conceito mostrou que o percentual de acerto esteve muito próximo do percentual dado a uma determinada alternativa incorreta. Consideramos que isso possa ter ocorrido pelo fato de a pergunta ter sido feita utilizando-se uma analogia, o que dificultou a compreensão dos estudantes. Quando a aprendizagem ocorre de maneira significativa o estudante é capaz de aplicar os conceitos apreendidos em outra situação, como por exemplo em uma analogia. Só obtém êxito em questões que envolvem analogias quem aprendeu de maneira significativa (Amabis, comunicação pessoal).

De acordo com Galagovsky e Adúriz-Bravo (2001), o modelo didáticoanalógico de ensino possibilita aprendizagens verdadeiramente significativas. De acordo com esse modelo, as analogias devem ser criadas pelo próprio aprendiz, o que possibilita que o estudante estabeleça relações válidas e, portanto, que a aprendizagem seja realmente significativa. Quando é o estudante quem elabora as próprias relações entre sua analogia e os conceitos, este conceito liga-se em sua rede conceitual e passa a fazer parte de um todo mais amplo.

Como os estudantes não estão habituados ao uso de analogias e, provavelmente, devido a prática da memorização de conceitos, não conseguiram obter êxito na resposta à essa questão. 
Caballer e Gimenez (1992) sugerem que os processos de aprendizagem ao longo da vida escolar dos estudantes não conseguem incorporar de forma coerente e estável os conhecimentos assimilados. É o que verificamos em nosso trabalho, a partir das diversas respostas incoerentes que os estudantes do último ano dos cursos de Ciências Biológicas apresentaram.

Notamos uma certa heterogeneidade de resultados dentro de uma mesma Instituição de Ensino. Isso pode ser explicado por meio da Teoria das Inteligências Múltiplas (Gardner, 1985).

Gardner (1989) sugere que as habilidades humanas não são organizadas de forma horizontal; ele propõe que se pense nessas habilidades como organizadas verticalmente, e que, ao invés de haver uma faculdade mental geral, como a memória, talvez existam formas independentes de percepção, memória e aprendizado, em cada área ou domínio, com possíveis semelhanças entre as áreas, mas não necessariamente uma relação direta.

$\mathrm{Na}$ perspectiva da aprendizagem significativa de Ausubel (Apud Moreira, 1999), é importante considerar que o estudante é um sujeito que está atribuindo sentidos e significados ao mundo e aos objetos que os cercam.

Matui (2002) afirma que um dos prazeres mais naturais e espontâneos para o ser humano é o de dar significação às coisas e ao universo. $O$ homem faz isso desde o nascimento até a morte.

$\mathrm{O}$ estudante, independente do seu grau de escolaridade, vem para a escola muito curioso e esperançoso de enriquecer o seu poder de dar significação às coisas e compreendê-las. Ele é ativo e iniciador de atividades. Para o autor, não existe estudante apático, o que pode ocorrer é que ele esteja apático.

É assemelhando uma coisa à outra que damos significação às coisas. Para a teoria da aprendizagem significativa, um objeto tem sentido ou significado porque é passível de ser assimilado, ou seja, de ser incorporado e passível de estabelecer relações com o conhecimento pré-existente. É sempre pela mediação de alguma coisa, de pessoas ou grupos que fazemos assimilação ou significação.

Essa linha de raciocínio estende-se ao Ensino Superior, aonde os estudantes chegam cheios de desejo de aprender e durante o curso vão se decepcionando e acabam por assistir aulas que não despertam interesse e não possibilitam uma 
aprendizagem efetiva. O resultado disso é o quadro que encontramos em nossa pesquisa: estudantes que estão saindo da Universidade desconhecendo conceitos básicos da Biologia.

Esse resultado se dá, segundo Amabis (2001), principalmente, pelo fato de se trabalhar um currículo centrado no professor, cujo principal objetivo é transmitir um corpo organizado de conhecimentos. Assume-se que quando um estudante adquiriu uma massa de conhecimentos ele pode aplicá-la na solução de problemas do cotidiano. Isso é o inverso do que acontece na pesquisa científica e na vida em geral, onde o aprendizado ocorre à medida que tentamos resolver os problemas que surgem, ou seja, no dia-a-dia o problema aparece primeiro. Para Popper (1999), a vida é a solução de problemas e descoberta de novos fatos, de novas possibilidades, por meio da experimentação de possibilidades concebidas na nossa imaginação. Desde a educação infantil, os estudantes são expostos a modelos de aprendizagem no qual o professor decide que informação deve ser aprendida, como ela deve ser aprendida, em que seqüência e em que velocidade deve ocorrer a aprendizagem. Raramente o estudante pode experimentar o excitamento intelectual envolvido na busca do conhecimento, ou sentir o fervor do questionamento científico. O professor fornece as informações para os estudantes como um produto acabado e não revela seu próprio esforço criativo para fornecer o material dessa forma. O papel passivo do estudante contrasta com a postura ativa do professor na preparação das aulas. A atividade do professor promove aprendizado para ele, não para os estudantes. Se nós realizamos o trabalho mental para o aprendiz, nós reduzimos seu investimento no aprendizado, prejudicando seu desempenho (Amabis,2001).

Para finalizar o trabalho de pesquisa investigamos se nas aulas são abordados conceitos por meio do uso de modelos e analogias e a opinião dos estudantes sobre a importância no uso dos modelos e analogias como metodologias facilitadoras do processo ensino-aprendizagem.

Todos os estudantes, ou seja, 100\% dos entrevistados, responderam que de modo geral o conteúdo era bastante extenso e tratado de maneira descritiva, descontextualizada e desinteressante. De acordo com o depoimento dos entrevistados, o conteúdo era transmitido aos estudantes como verdade absoluta, sendo algo pronto e acabado. Assim, o estudante não é estimulado a pensar e não é 
instigado a construir seu conhecimento. Encontramos estudantes que destacam que não há preocupação com a aprendizagem do estudante e que as aulas não são atualizadas, que todos os anos o conteúdo é igual, independente do que está acontecendo no mundo.

“...Existia uma falta de percepção pedagógica dos professores. O intuito deles era que os estudantes decorassem e não que aprendessem. Na verdade acho até que eles gostariam que aprendesse, mas a metodologia que eles usavam não... metodologia de armazenamento da informação e não de conhecimento da informação."

“...Tem professor que é super tradicional e acho que a primeira transparência que ele usou na primeira turma que ele deu aula, acho que ele usa a mesma até o hoje, o slide está até meio amarelo, meio mofado, porque são as mesmas coisas e se você assiste uma aula dele hoje ou daqui a um ano vai ser igual, a mesma aula, independe dos estudantes, independe do que está acontecendo no mundo..."

De acordo com os depoimentos dados pelos estudantes, ficou evidente que em cada Instituição de Ensino sempre há um ou outro professor que procura fazer um trabalho diferenciado, mas essa prática constitui uma exceção dentro das Instituições.

Todos os alunos entrevistados apresentam críticas à metodologia clássica de ensino e a maioria defende o uso de modelos e analogias como um elemento facilitador do processo ensino-aprendizagem. Alguns, no entanto, não defendem uma ou outra metodologia, apenas afirmam que da maneira como estão sendo trabalhados os conteúdos nas aulas é impossível ocorrer um aprendizado efetivo.

Gilbert e Boultier (2000) definem modelos como sendo uma representação de uma idéia, objeto, evento, processo ou um sistema. Os modelos são representações simplificadas de fenômenos e idéias e ocupam uma posição intermediária entre a realidade e um modelo mental.

Para Ritchie e colaboradores (1997) os modelos mentais podem ser classificados como uma forma especial de modelos que são definidos como uma 
construção cognitiva humana usados para descrever e explicar fenômenos que não podem ser diretamente experienciados.

Apesar de muito úteis no ensino de Ciências, os modelos devem ser utilizados com cautela, pois apresentam algumas limitações e se não forem corretamente utilizados podem prejudicar o aprendizado ao invés de facilitá-lo.

Coll (2005) destaca um aspecto da literatura que consiste na identificação de divergências atribuídas ao uso de modelos por aprendizes e cientistas. Os cientistas entendem que modelos são invenções humanas baseadas em uma compreensão incompleta de como a natureza funciona. Cientistas usam modelos em uma situação muito prática e realista, vendo-os como ferramentas para ajudar na compreensão do mundo. Conseqüentemente, muitos modelos são impróprios ou limitados em alguns aspectos e o uso prático desses modelos que são conhecidos por conter limitações é uma das características que diferencia o cientista do aprendiz. Ao lançar mão de modelos como estratégia de ensino, devemos deixar claro aos estudantes quais são as limitações do modelo utilizado. O objetivo do uso de modelos é concretizar conceitos muito abstratos para facilitar sua compreensão, mas deve-se tomar o máximo de cuidado para não correr o risco de simplificação e banalização do conceito.

Em relação à dificuldade de responder questões que envolvam analogias, Galagovsky e Adúriz-Bravo (2001) colocam que se a analogia for feita pelo professor não surtirá o efeito desejado, pois assim, o estudante lembra a analogia e a palavra ou situação em que foi utilizada, porém não é capaz de lembrar o conceito. Para os autores, quando o estudante é estimulado a estabelecer suas próprias relações, criando sua própria analogia, essa passa a fazer parte de sua rede conceitual e o estudante não esquece o conceito, pois construiu uma maneira de aprender e passa a entender como se dá sua aprendizagem.

Os resultados desse trabalho nos permitem inferir que os estudantes que estão finalizando os cursos Superiores de Ciências Biológicas apresentam dificuldades conceituais básicas em conteúdos fundamentais de Genética e disciplinas correlatas.

Remetendo-nos aos estágios de alfabetização biológica proposto por Krasilchik (2001), concluímos que pouco mais de 37\% dos formandos encontram-se 
no estágio nominal. Isto significa que esses estudantes são capazes de identificar termos, mas sua conceituação é ingênua ou desconhecida. Pouco mais de $40 \%$ dos entrevistados estão no estágio da alfabetização funcional, no qual os termos são definidos por memorização, sem a compreensão real dos seus significados.Mais de $21 \%$ encontram-se no estágio estrutural, no qual são compreendidos os conceitos e princípios unificadores da Biologia.

Em algumas ocasiões, os resultados insatisfatórios são atribuídos ao desinteresse do estudante, porém, em nossas entrevistas, notamos que os estudantes não estão alheios e desinteressados, e chegam a nos dar pistas para a melhoria da qualidade do ensino. Para Trivelato (1988), os estudantes não são generalizadamente desinteressados; ao contrário, demonstram estar prontos a traduzir as informações transmitidas pela escola em conhecimentos úteis ao seu dia-a-dia. Cabe, portanto, à escola não sufocar este anseio por compreender a vida, despejando sobre os estudantes informações estéreis, por serem despidas de significado e relevância.

É preciso preservar e resgatar, quando for o caso, o prazer da aprendizagem e a curiosidade em compreender os fatos da vida em todos os níveis de escolarização. 


\section{Conclusões}

Os resultados obtidos nessa pesquisa permitem concluir em relação aos estudantes participantes que:

- Os estudantes não chegam a alcançar os objetivos porpostos pelo MEC, no que diz respeito à Genética e disciplinas correlatas.

- Não ocorreu aprendizagem significativa dos conceitos de Genética, Biologia Molecular e Biologia Celular. Inferimos que ocorreu apenas aprendizagem mecânica, por memorização.

- A heterogeneidade observada em uma mesma Instituição de Ensino poderia indicar que cada estudante aprende de uma determinada maneira, o que nos indica que diferentes estratégias de ensino devem ser utilizadas.

- De acordo com os estágios de alfabetização biológica proposto por Krasilchik (2001), nenhum estudante está no estágio multidimensional. 


\section{Resumo}

A Biologia hoje é a mais comentada ciência e a que ocupa maior espaço na mídia. No entanto, isso não significa que os conceitos biológicos sejam de conhecimento público, nem tampouco dos estudantes de Biologia. Para analisar o conhecimento de conceitos fundamentais de Genética, Biologia Molecular e Biologia celular apresentado por graduandos do último ano de Cursos Superiores de Ciências Biológicas é que realizamos esse trabalho de pesquisa. Iniciamos o trabalho com a seleção das questões do Exame Nacional de Cursos de Biologia (Provão) do ano de 2002 que abordavam conceitos de Genética e disciplinas correlatas, analisamos o relatório do ENC-BIO/2002 expedido pelo MEC, aplicamos questionários com as questões analisadas do ENC-BIO/2002 em 72 estudantes do último ano dos cursos de Ciências Biológicas, realizamos 33 entrevistas semi-estruturadas com estudantes do último ano dos cursos de Ciências Biológicas e, por fim, analisamos os resultados apresentados pelo relatório do MEC e das entrevistas realizadas. Concluímos que os estudantes não chegam a alcançar os objetivos que a ele são atribuídos pelo MEC, no que diz respeito à Genética e disciplinas correlatas e a maioria apresenta aprendizagem mecânica. 


\section{Abstract}

Biology today is the most talked about science and also the one which gets the largest media coverage. However, that doesn't mean that the biological concepts are of public knowledge, neither are they of knowledge of Biology students. The main objective of this research work is to analyze the knowledge of fundamental concepts of Genetics, Molecular Biology and Cellular Biology of undergraduate students, who were majoring in Biological Sciences, in their senior year. We began our work with some selected questions from the National Exam of Biology Courses ("Provão") for 2002, we chose the ones which involved concepts of Genetics and other correlated disciplines, we analyzed the ENC-BIO/2002 report prepared by the $M E C$, we prepared questionnaires with the analyzed questions from the ENC$\mathrm{BIO} / 2002$ and distributed them to 72 senior students who were majoring in Biological Sciences, we conducted 33 semi-structured interviews with senior students majoring in Biological Sciences and, finally, we analyzed the results presented by the $M E C$ report and by the interviews. We concluded that the students did not achieve their goals, which were established by the MEC. These goals were related to Genetics and other correlated disciplines and most of them demonstrated only a mechanical learning. 


\section{Bibliografia}

AMABIS, J. M. A revolução na Genética: Um tema para a Escola Secundária? In Encontro Perspectivas do Ensino de Biologia, 3, 1988, São Paulo.Anais...USP. Faculdade de Educação,1988. p. 19-24.

.A Revolução na Genética: Um tema para a escola secundária? In. Encontro sobre temas de Genética e melhoramento, 18, 2001, Piracicaba. Anais. Piracicaba: USP,2001. p. 7-10.

AUSUBEL, D. P.; NOVAK, J. D.; HANESIAN, H. Psicologia Educacional. Rio de Janeiro: Interamericana, 1980.

AYUSO, E.; BANET, E.; ABELLÁN, T. .Introdución a la Genética em la enseñanza secundaria y el bachillerato: $I_{\text {¿Resolución de problemas o }}$ realización de ejercicios? Enseñanza de lãs Ciências, v.14, n. 2., p. 127-141, 1996.

BAHAR, M.; JOHNSTONE, A. H.; HANSELL, M. H. Revisiting learning difficulties in biology. Journal of Biological Education, v. 33, n. 3., p. 84-86, 1999.

BANET, E.; AYUSO, E. Teaching genetics at secondary school: A strategy for teaching aboute the location of inheritance information. Science Education, v. 84, n. 3., p. 313-351, 2000. 
BRASIL. Portaria 296 de 30 de janeiro de 2002. Diário Oficial da União, Brasília, 01 de fevereiro de 2002.

- Ministério da Educação e Cultura. Exame Nacional de Cursos de Biologia. INEP., Brasília, 2002.

Ministério da Educação e Cultura. Diretrizes Curriculares Nacionais para os cursos de Ciências Biológicas. Brasília, 2001.

.Parâmetros Curriculares Nacionais para o Ensino Médio:

Ciências da Natureza, Matemática e suas Tecnologias. Brasília, 1999.

. Ministério da Educação e Cultura. Relatório do Exame Nacional de Cursos de Biologia (Provão) de 2002. Brasília, 2003. 1 disquete, $3 \frac{1}{2} 2$ po. Word for Windows 7.0.

CABALLER, M. J.; JIMÉNEZ, I. Las ideas de los alumnos y alumnas acerca de la estructura celular de los seres vivos. Enseñanza de las Ciências, v. 10, n. 2., p.172$180,1992$.

CAMPBell, N. A.; REECE, J. B.; MitChell, L. G. Biology, $5^{\text {th }}$ edition. Benjamim Cummins, 1999. 
COLL, R. K. The role of models/and analogies in science education: implications from research. International Journal of Science Education, v. 27, n. 2., p.183-198, 2005.

CONDIT, C. M.; ACHTER, P. J.; LAUER, SEFCOVIC, E. The changing meanings of "Mutation": a contextualized study of public discourse. Human Mutation, v.19., p.69-75, 2002.

CHO, H. H; KAHLE, J. B.; NORDLAND, F. H. An investigation of high schoolbiology textbooks as sources of misconceptions and dificulties in genetics and some suggestions for teaching genetics. Science Education, v. 69, n. 5, p. 707$719,1985$.

DEADMAN, J. A.; KELLY, P. J. What do secondary schoolboys understand about evolution and hereditary before they are thaugh the topics? Journal of Biological Education, v. 12, n. 1, p. 7-15, 1978.

DUIT, R. On role of analogies and metaphors in learning science. Science Education, v. 75, n. 6, p. 649-672, 1991.

FINLEY, F. N.; STEWART, J.; YARROCH, W. L. Teachers' perceptions of important and difficult science content. Science Education, v. 66, n. 4, p. 531-538, 1982. 
FISHER, K. M. .Amino acids translation: A misconception in Biology. Proc. Int. Seminar: Misconceptions in Science and Mathematics. Ithaca, NY: Cornell University., 1983.

FRANCO, C.; BARROS, H. L.; COLINVAUX, D.; KRAPAS, S.; QUEIRÓZ, G.; ALVES, F. From scientists' and inventors' minds to some scientific and technological products, mental models and conceptions. International Journal of Science Education, v. 21, n. 3, p. 277-291, 1999.

GALAGOVSKY, L.; ADÚRIZ-BRAVO, A. Modelos y analogias em la enseñanza de lãs ciências naturales. El concepto de modelo didáctico analógico. Enseñanza de las Ciências, v. 19, n. 2, p. 231-242, 2001.

GAMA, M. C.S. A teoria das inteligências múltiplas e suas implicações para a educação.Disponível em:< http://www.psicopedagogia. com.br/artigos/ artigo. asp? entrID=18 >Acesso em 01 dez 2005.

GARDNER, H. Frames of mind. Basic Books Inc, New York, 1985

.The mind's new science. Basic Books Inc, New York, 1987.

GARDNER, H.; HATCB, T). Multiple intelligences go to school: educational implications of the theory of Multiple Intelligences. Educational Researcher, v. 18, n. 8, p. $4-10,1989$ 
GILBERT, J.; BOULTIER, C.(eds) .Developing models in Science Education. Dordrecht: Kluwer, p. 3-18, 2000.

GRECA, I.; MOREIRA, M. A. Mental models, conceptual models and modelling. International Journal of Science Education, v. 22, n. 1, p. 1-11, 2000.

GRIFFITHS, A. J. F.; GELBART, W. M.; MILLER, J. H.; LEWONTIN, R. C. Genética Moderna. Rio de Janeiro: Guanabara Koogan, 2001.

JOHNSTONE, A. H.; MAHMOUND, N. A. Isolating topics of high perceived difficulty in school biology. Journal of Biological Education, v. 14, n. 2, p.163-166, 1980

KRASILCHIK, M. Ensino de Genética: passado, presente e futuro. In. Encontro sobre temas de Genética e melhoramento, 18, 2001, Piracicaba. Anais. Piracicaba: USP,2001. p. 37-41.

LAVILLE, C.; DIONNE, J. A construção do saber: manual de metodologia da Pesquisa em ciências humanas. Porto Alegre: Artes Médicas Sul, 1999.

LAW, N.; Lee, Y. Using na iconic modelling tool to support the learning of genetics concepts. Journal of Biological Education, v. 38, n. 3, p. 118-124, 2004.

LEWIS, J.; KATTMANN, U.Traits, genes, particles and information: Re-visiting students' understandings of genetics. International Journal of Science Education, v. 26, n. 2, p.195-206, 2004. 
LEWIS, J.; LEACH, J.; WOOD-ROBINSON, C. All in genes? - Young people's understandin of the nature of genes. Journal of Biological Education, v. 34, p. 7479, 2000.

LONGDEN, B. Genetics: Are the inherent learning difficulties? Journal of Biological Education, v. 16, n. 2, p.135-140, 1982.

LUDKE, M.; ANDRÉ, M. E .D .A. Pesquisa em educação: abordagens qualitativas. São Paulo:Editora Pedagógica e Universitária, 1986.

MAHADEVA, M. N.; RANDERSON, S. Mutation: Mumbo jumbo. Science Teaching, v. 49, p. 34-38, 1982.

MATUI, J. Construtivismo: teoria construtivista sócio-histórica aplicada ao ensino. São Paulo: Moderna, 2002.

MOREIRA, M. A. Teorias de aprendizagem. São Paulo: Editora Pedagógica e Universitária, 1999.

OLBY, R. Quiet debout for the doublé helix. Nature v. 421, p. 402-405, 2003.

POPPER, K. R. Conhecimento Objetivo. Belo Horizonte: Itatiaia, 1999. 
RITCHIE, S. M.; TOBIN, K.; HOOK, K. S. Teaching referents and the warrants used to best the viability of students' mental models: is there a link? Journal of Reasearch in Science Teaching, v. 34, n. 3, p. 223-238, 1997.

SHAPIRO, M. A. Analogies, visualization and mental processing of science stories, 1985. In: DUIT, R. On role of analogies and metaphors in learning science. Science Education, v. 75, n. 6, p. 649-672, 1991.

SILVEIRA, R. V. M. (2003).Como os estudantes do Ensino Médio relacionam os conceitos de localização e organização do material genético? São Paulo: Instituto de Biociências; Universidade de São Paulo, 2003. Dissertação de Mestrado. em Biologia/Genética.

SLACK, S. J.; STEWART, J. Hhigh school students' problem-solving performance on realistic genetics problems. Journal of Research in Science Teaching,v. 27, n. 1, p.55-67, 1990.

STEWART, J. Difficulties experienced by high school students when learning basic Mendelian genetics. American Biology Teacher, v. 44, n. 2, p. :80-84, 1982.

TOLMAN, R. R. Difficulties in genetics problem solving. American Biology Teacher, v. 44, p. 525-527, 1982.

TORRES, B. B. (2001).Educação em Ciências Biológicas. In: Encontro sobre temas de Genética e Melhoramento, 18, 2001, Piracicaba, Anais. Piracicaba. USP, 2001. 
TRIVELATO, S. L. F. Ensino de Genética: Um novo ponto de vista. São Paulo :FEUSP, 1988.

WOOD-ROBINSON, C.; LEWIS, J.; LEACH, J.; DRIVER, R. Genética y formación científica: resultados de um proyecto de investigación y sua implicaciones sobre los programas escolaresy la enseñanza. Enseñanza de las Ciências, v. 16, n. 1, p. 43-61, 1998. 


\section{Anexos}

\section{Questões do Exame Nacional de Cursos de Biologia/2002}

Para responder às questões de números 1 e 2 considere o texto abaixo.

A anemia falciforme é uma doença hereditária com herança autossômica recessiva, que tem grande incidência nas populações africanas negras. Os indivíduos afetados são homozigóticos ( $\mathrm{HbS}$ / HbS) em relação a uma alteração na hemoglobina. Os indivíduos heterozigóticos ( $\mathrm{HbA} / \mathrm{HbS})$ geralmente não manifestam os sintomas da doença e são denominados portadores do traço falcêmico. O pesquisador Vernon Ingram observou, em 1957, que a única diferença entre a hemoglobina mutante dos afetados e a hemoglobina normal é a presença do aminoácido valina em lugar do ácido glutâmico, na posição 6 em uma das cadeias da molécula.

1. Do ponto de vista histórico, é correto afirmar que o principal impacto da pesquisa de Ingram foi:

(A) decifrar o código genético.

(B) evidenciar a relação direta entre o RNA mensageiro e a cadeia de aminoácidos nas proteínas.

(C) comprovar que era possível seqüenciar as bases do DNA por meio dos aminoácidos.

(D) demonstrar que as mutações podem causar alterações nas cadeias polipeptídicas.

(E) verificar que as mutações causam alterações nas moléculas de RNA mensageiro. 
2. Dentre quatro populações pequenas e geograficamente próximas de descendentes de escravos africanos, em apenas uma foram detectados portadores do traço falcêmico. Uma vez que nenhuma das populações está sujeita a fluxo gênico, a observação pode ser explicada por:

(A) taxas de recombinação diferentes em cada população.

(B) taxas de mutação constantes em cada população.

(C) deriva genética e migração.

(D) altas taxas de endogamia em cada população.

(E) diferentes genótipos fundadores em cada população e pequeno tamanho populacional.

3. Na revista Science de 14 de dezembro de 2001, um grupo de pesquisadores relatou a cura da anemia falciforme em camundongos, através da terapia gênica. A partir de um retrovírus modificado, a equipe construiu um vetor para a introdução do gene terapêutico. A estratégia do experimento baseou-se no fato de haver integração, ao genoma das células infectadas, de uma cópia do:

(A) RNA viral, retrotranscrita em DNA.

(B) DNA viral, transcrita em RNA.

(C) RNA viral, retrotranscrita em RNA.

(D)RNA viral, embora ambos os ácidos nucléicos tenham sido introduzidos nas células.

(E) DNA viral, embora ambos os ácidos nucléicos tenham sido introduzidos nas células.

O texto abaixo refere-se às questões de número 4 a 6 .

João trabalha em uma confeitaria cujo proprietário é alemão. Todas as manhãs este deixa, sobre a mesa da cozinha, uma receita em português e os ingredientes de um bolo que João deve preparar. A receita original, escrita em alemão, fica guardada no 
escritório da confeitaria. Somente o patrão de João pode abrir o escritório e escrever, em português, a receita a ser utilizada naquele dia.

4. Para explicar a leigos o funcionamento de uma célula, fazendo uma analogia com o texto, o bolo, seus ingredientes, a receita em português e a receita em alemão corresponderão, respectivamente, a:
(A) aminoácido, nucleotídeos, DNA e RNA.
(B) nucleotídeo, aminoácidos, RNA e DNA.
(C) Polipeptídeo, aminoácidos, RNA e DNA
(D) DNA, RNA, polipeptídeo e aminoácido.
(E) DNA, aminoácidos, nucleotídeos e polipeptídeos .

5. Continuando a analogia, o escritório, a cozinha e João corresponderão,respectivamente, aos seguintes componentes de uma célula de eucarioto:
(A) citoplasma, núcleo e cromossomo.
(B) núcleo, citoplasma e ribossomo.
(C) citoplasma, núcleo e membrana nuclear,
(D) núcleo, citoplasma e cromossomo.
(E) cromossomo, membrana nuclear e citoplasma.

5. Alguns bolos são servidos assim que saem do forno, enquanto outros recebem acabamento especial. Na analogia considerada, o local da confeitaria onde os bolos recebem recheio e cobertura, corresponde
(A)à mitocôndria.
(B) ao retículo endoplasmático rugoso. 
(C) ao peroxissomo.

(D) ao lisossomo.

(E) ao complexo de Golgi

7. A clonagem animal vem sendo realizada desde a década de 50. Entretanto, em 1997, o experimento que levou ao nascimento da ovelha Dolly causou impacto científico e social por ser o primeiro a demonstrar que células:

(A) germinativas de mamíferos, quando clonadas, podem originar indivíduos que chegam à fase adulta, porém são estéreis.

(B) germinativas de mamíferos, quando clonadas, podem originar novas células germinativas e novas células somáticas.

(C) somáticas diferenciadas, obtidas de mamíferos adultos, podem originar indivíduos viáveis.

(D) somáticas diferenciadas sofrem modificações do material genético que não podem ser revertidas.

(E) somáticas indiferenciadas, obtidas de fase embrionária são incapazes de gerar indivíduos viáveis.

8. As mitocôndrias possuem uma única molécula de DNA circular. Isto torna a organização do material genético dessas organelas semelhante à organização do material genético presente em
(A) bactérias e cloroplastos.
(B) plantas e algas verdes.
(C) fungos e vírus.
(D) vírus e bactérias.
(E) protozoários e cloroplastos. 


\section{Parte I. Autorização}

$\mathrm{Eu}$ estudante de graduação do curso de Ciências Biológicas da Universidade. autorizo a utilização dos resultados de minhas respostas ao teste elaborado pela professora Cátia Sueli Fernandes Primon, aluna de pós-graduação (área Biologia/genética) do Instituto de Biociências da Universidade de São Paulo, em sua dissertação de mestrado e publicações delas advindas, desde que isso não implique em minha identificação ou menção de meu nome.

São Paulo, ___ de novembro de 2003.

Assinatura

Nome legível 


\section{Parte II. Disponibilidade para entrevista}

As questões que você acabou de responder foram retiradas do Exame Nacional de Cursos (Provão) de Biologia do ano de 2002. A próxima etapa desta pesquisa será a entrevista com os estudantes que participaram desta primeira etapa. Durante a entrevista você terá a oportunidade de verificar como foi seu desempenho nas questões bem como esclarecer dúvidas e discutir aspectos importantes da sua formação. Você teria disponibilidade para participar da segunda etapa (entrevista) em data e local que lhe for conveniente?

Em caso afirmativo preencha abaixo.

Nome

Telefone

Celular

e-mail

Disponibilidade para entrevista:

\begin{tabular}{|l|l|}
\hline Dia da semana & Horário \\
\hline Segunda-feira & \\
\hline Terça-feira & \\
\hline Quarta-feira & \\
\hline Quinta-feira & \\
\hline Sexta-feira & \\
\hline Sábado & \\
\hline Domingo & \\
\hline
\end{tabular}


